INEL-94/0139

\title{
DISCLAIMER
}

This report was prepared as an account of work sponsored by an agency of the United States Government. Neither the United States Government nor any agency thereof, nor any of their employees, makes any warranty, express or implied, or assumes any legal liability or responsibility for the accuracy, completeness, or usefulness of any information, apparatus, product, or process disclosed, or represents that its use would not infringe privately owned rights. Reference herein to any specific commercial product, process, or service by trade name, trademark, manufacturer, or otherwise does not necessarily constitute or imply its endorsement, recommendation, or favoring by the United States Government or any agency thereof. The views and opinions of authors expressed herein do not necessarily state or reflect those of the United States Government or any agency thereof.

\section{Final Report \\ Decontamination and Dismantlement of the Old Hot Laundry, CFA-669}

\author{
D. L. Smith \\ E. F. Perry
}

Published January 1995
Idaho National Engineering Laboratory Lockheed Idaho Technologies Company Idaho Falls, Idaho 83415

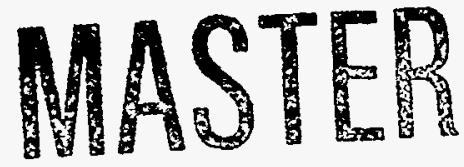

Prepared for the

U.S. Department of Energy

Assistant Secretary for Environmental Managernent

Under DOE Idaho Operations Office

Contract DE-AC07-94ID13223 


$\therefore$




\section{DISCLAIMER}

Portions of this document may be illegible in electronic image products. Images are produced from the best available original document. 


\section{ABSTRACT}

This report describes the tasks performed to decontaminate and dismantle the old hot laundry, CFA-669, located at the Idaho National Engineering Laboratory Central Facilities Area. The report describes the site before and after decontamination and dismantlement, processes used, cost and duration, and waste volume generated. 


\section{EXECUTIVE SUMMARY}

This final report describes the decontamination and dismantlement (D\&D) of the old hot laundry, CFA-669, located at the Idaho National Engineering Laboratory (INEL) Central Facilities Area (CFA). The report describes the site before and after D\&D, processes used, cost and duration, and waste volume generated. In addition, lessons learned are presented.

Pre-D\&D characterization indicated gross alpha concentrations in the building ranged from 6 to $310 \mathrm{pCi} / \mathrm{g}$ and gross beta measurements from 6 to $15,000 \mathrm{pCi} / \mathrm{g}$. Gamma spectrum analysis identified cobalt- 60 , cesium-137, antimony-125, europium-152, europium-154, and niobium-94.

Three alternatives for $\mathrm{D} \& \mathrm{D}$ were considered:

- Do nothing (continue surveillance and maintenance)

- Partial dismantlement and renovation

- Total dismantlement.

Total dismantlement was the D\&D alternative chosen.

Following site preparation, the radiologically contaminated, asbestos-insulated piping in all rooms (except the boiler room) was removed, bagged, and placed in boxes for disposal. Following asbestos removal, the contaminated equipment in all rooms (except the boiler room) was sized or cut and then removed and boxed for disposal.

The boiler room (Room 110) contained an asbestos-insulated boiler and large amounts of asbestos-insulated piping. There was also mercury-contaminated debris on the floor and in the drain trench. The mercury-contaminated debris and the asbestos insulation were removed, packaged, and appropriately disposed of.

The remaining, uncontaminated equipment and components were then removed and excessed for reuse or disposed of in the CFA landfill.
After all equipment had been removed, the contaminated concrete floor and walls were scabbled. The concrete drain trench in Room 108 was scabbled and chipped. However, because of the depth of contamination, the scabbling was unsuccessful and decontamination of the entire trench was delayed until the building was demolished.

Contaminated filter units on the roof were disconnected, lowered to the ground, and boxed for sizing at the Waste Experimental Reduction Facility (WERF).

The roofing material was removed from the concrete roof panels and disposed of as either radioactive asbestos waste or uncontaminated asbestos waste.

After removal of the roofing material, the previously identified fixed contamination inside the building was removed by scabbling, chipping, and vacuuming. Following the cleanup of the building interior, the concrete roof panels were lowered to the ground, radiologically surveyed, and disposed of in the CFA landfill.

The few areas of inaccessible contamination in the concrete blocks were removed by carefully dismantling the walls, surveying suspected blocks, and segregating contaminated from uncontaminated blocks. The contaminated trench, which had been temporarily covered with steel plates, was now removed by sawing and jackhammering; it was then packaged and disposed of along with contaminated soil removed from the area beneath the concrete trench. Next, using a concrete processor, the outside walls were demolished.

The concrete slab was verified releasable, jackhammered, loaded into dump trucks, and disposed of in the CFA landfill along with the excavated footings.

Uncontaminated piping was removed and disposed of in the CFA landfill. Radiologically contaminated piping and contaminated soil beneath and adjacent to the piping were removed, bagged, 
and boxed for disposal at the Radioactive Waste Management Complex (RWMC).

A two-phase post-D\&D characterization was performed after all detected radioactively contaminated soil had been removed. Phase I included sampling and analyzing the trench and berm formed during excavation of the 8-in. contaminated sewer line and the trench formed during excavation of the soil beneath the concrete trench. Phase II consisted of sampling and analyzing the entire CFA-669 site following backfilling and gridding. An area survey for beta-gamma radioactivity was also performed. The post-D\&D characterization results were entered into the Residual Radioactivity (RESRAD) computer code, and the calculation indicated that the CFA- 669 site is releasable according to DOE Order 5400.5 guidelines.

Most waste generated during this project was uncontaminated, resulting in its disposal in the CFA landfill. Radioactive waste was shipped to either RWMC or WERF. Hazardous waste was shipped to the Hazardous Waste Storage Facility at CFA. No mixed waste was generated. Some items were excessed for recycling.

Project duration encompassed January 1991 through December 1994; total project cost was $\$ 2.8$ million, which included both labor and nonlabor dollars. The project was completed ahead of schedule and under budget. During the project, there were six significant lessons-learned. 


\section{CONTENTS}

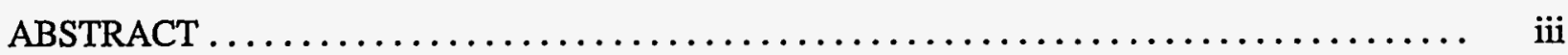

EXECUTIVE SUMMARY $\ldots \ldots \ldots \ldots \ldots \ldots \ldots \ldots \ldots \ldots \ldots \ldots \ldots \ldots \ldots \ldots \ldots \ldots \ldots, \mathrm{v}$

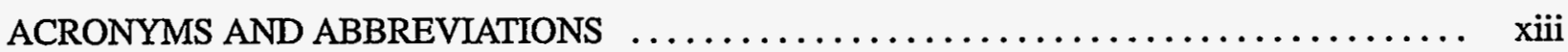

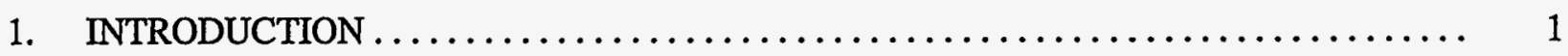

2. FACILITY DESCRIPTION BEFORE D\&D $\ldots \ldots \ldots \ldots \ldots \ldots \ldots \ldots \ldots \ldots \ldots \ldots \ldots \ldots, 2$

2.1 Physical Description $\ldots \ldots \ldots \ldots \ldots \ldots \ldots \ldots \ldots \ldots \ldots \ldots \ldots \ldots \ldots \ldots \ldots \ldots \ldots \ldots, 2$

$2.1 .1 \quad$ Building Exterior $\ldots \ldots \ldots \ldots \ldots \ldots \ldots \ldots \ldots \ldots \ldots \ldots \ldots \ldots, 2$

2.1.2 Building Interior $\ldots \ldots \ldots \ldots \ldots \ldots \ldots \ldots \ldots \ldots \ldots \ldots \ldots, \quad 2$

2.1.3 Underground Piping $\ldots \ldots \ldots \ldots \ldots \ldots \ldots \ldots \ldots \ldots \ldots \ldots \ldots, 11$

$2.2 \quad$ Radiological Condition $\ldots \ldots \ldots \ldots \ldots \ldots \ldots \ldots \ldots \ldots \ldots \ldots \ldots \ldots \ldots \ldots \ldots \ldots \ldots, 11$

2.2.1 Gross Alpha and Beta Contamination $\ldots \ldots \ldots \ldots \ldots \ldots \ldots \ldots \ldots \ldots \ldots \ldots$

2.2.2 Gamma Contamination $\ldots \ldots \ldots \ldots \ldots \ldots \ldots \ldots \ldots \ldots \ldots \ldots \ldots \ldots \ldots \ldots \ldots, 11$

2.2.3 Other Radiological Measurements $\ldots \ldots \ldots \ldots \ldots \ldots \ldots \ldots \ldots \ldots \ldots \ldots \ldots \ldots \ldots, 11$

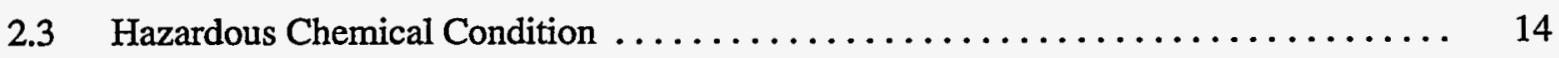

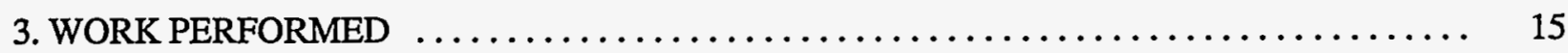

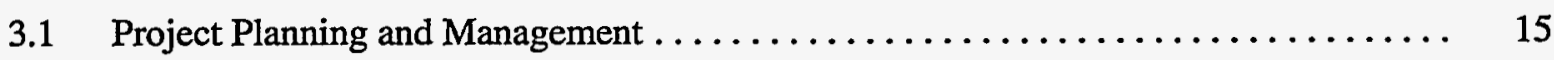

3.1.1 Preliminary Planning $\ldots \ldots \ldots \ldots \ldots \ldots \ldots \ldots \ldots \ldots \ldots \ldots \ldots, 15$

3.1.2 Final Planning $\ldots \ldots \ldots \ldots \ldots \ldots \ldots \ldots \ldots \ldots \ldots \ldots \ldots \ldots \ldots \ldots \ldots \ldots \ldots, 15$

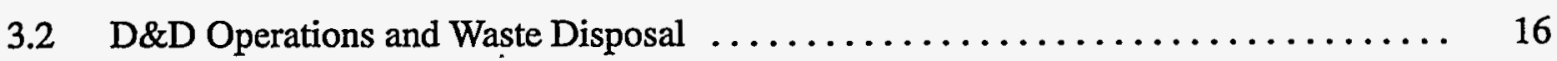

3.2.1 Site Facility Preparations $\ldots \ldots \ldots \ldots \ldots \ldots \ldots \ldots \ldots \ldots \ldots \ldots \ldots \ldots \ldots, \quad 16$

3.2.2 Removal and Disposal of Contaminated Asbestos ................ 16

3.2.3 Removal and Disposal of Contaminated Equipment $\ldots \ldots \ldots \ldots \ldots \ldots \ldots . \quad 21$

3.2.4 Removal and Disposal of Asbestos and Mercury from Room $110 \ldots \ldots \ldots .21$

3.2.5 Removal and Disposal of Uncontaminated Equipment ............. 21

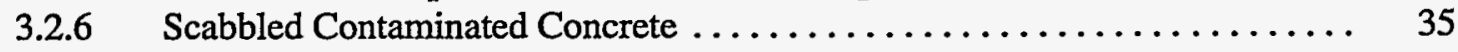

3.2.7 Removal and Disposal of Contaminated Filter Units on Roof ........... 35

3.2.8 Decontamination of Loose Contamination $\ldots \ldots \ldots \ldots \ldots \ldots \ldots \ldots . \quad 35$

3.2.9 Gridding and Survey of Building Interior $\ldots \ldots \ldots \ldots \ldots \ldots \ldots \ldots \ldots \ldots \ldots \ldots \ldots \ldots$

3.2.10 Removal and Disposal of Roofing Material .................. 41

3.2.11 Decontamination of Fixed Contamination in Building Interior .......... 41

3.2.12 Removal and Disposal of Concrete Roof Panels ................. 41

3.2.13 Re-Gridding and Re-Surveying Building Interior $\ldots \ldots \ldots \ldots \ldots \ldots \ldots, 41$

3.2.14 Decontamination of Remaining Fixed, Accessible Contaminations ....... 41

3.2.15 Survey of Building Exterior $\ldots \ldots \ldots \ldots \ldots \ldots \ldots \ldots \ldots \ldots \ldots \ldots \ldots \ldots \ldots, \quad 51$

3.2.16 Removal and Disposal of Inaccessible Contamination ............. 51 


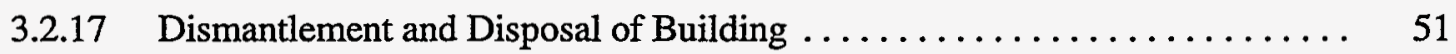

3.2.18 Removal and Disposal of Concrete Slab and Footings ............ 51

3.2.19 Excavation and Disposal of Uncontaminated Piping ............. 51

3.2.20 Excavation and Disposal of Contaminated Pipe and Associated Soil ..... 51

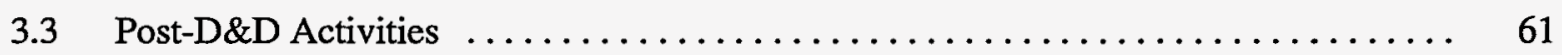

3.3.1 Preparation of Post-D\&D Characterization Plans . . . . . . . . . . 61

3.3.2 Performance of Post-D\&D Characterization ................... 61

3.3.3 Preparation of Site for Seeding (and Seeded the Area) $\ldots \ldots \ldots \ldots \ldots \ldots .61$

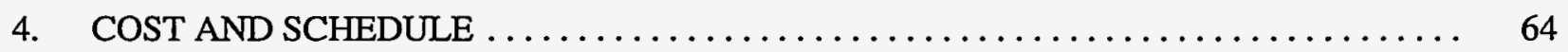

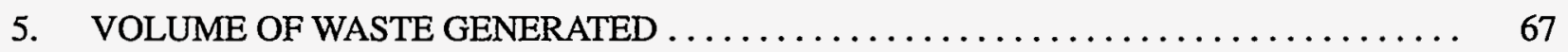

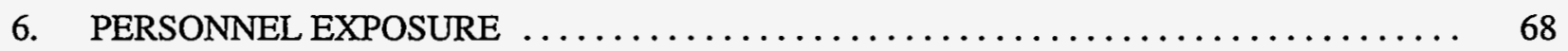

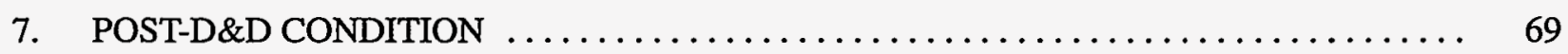

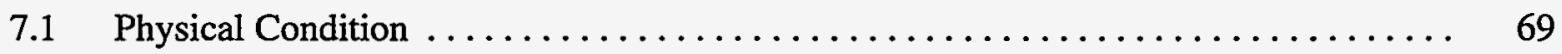

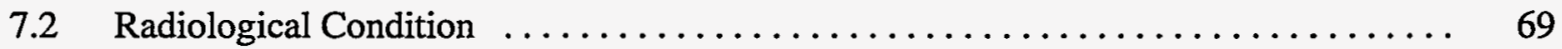

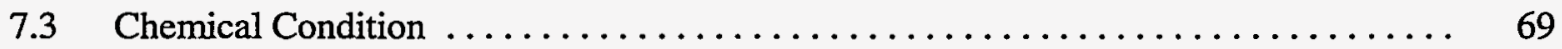

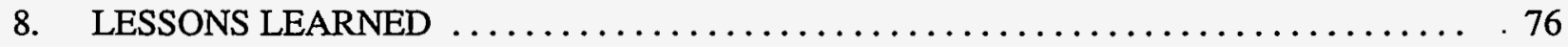

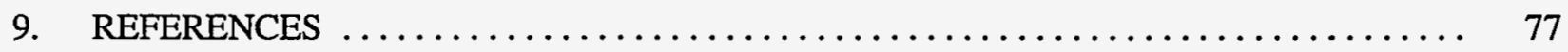

\section{FIGURES}

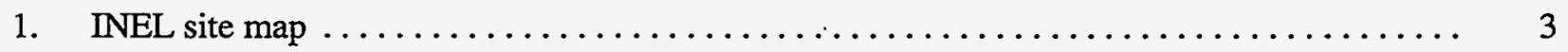

2. CFA and the relative location of CFA- 669 before $D \& D \ldots \ldots \ldots \ldots \ldots \ldots \ldots$

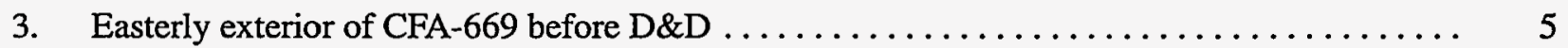

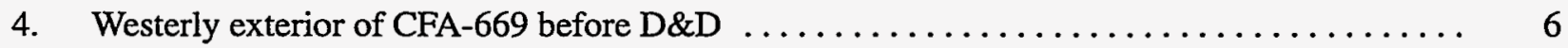

5. Southeasterly exterior of CFA- 669 before $D \& D \ldots \ldots \ldots \ldots \ldots \ldots \ldots \ldots \ldots \ldots \ldots$

6. Original floor plan of CFA- $669 \ldots \ldots \ldots \ldots \ldots \ldots \ldots \ldots \ldots \ldots \ldots \ldots \ldots \ldots \ldots$

7. Interior of Room 108 looking west. Dryers are on the left $\ldots \ldots \ldots \ldots \ldots \ldots \ldots$

8. Interior view of the boiler room. The south end of the boiler is on the left side

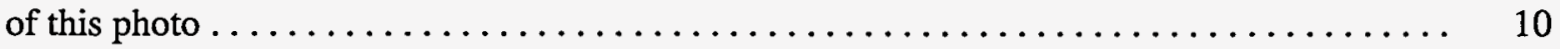

9. Aerial view of CFA- 669 looking southwest $\ldots \ldots \ldots \ldots \ldots \ldots \ldots \ldots \ldots \ldots \ldots \ldots$

10. Two sanitary sewer lines were cut and plugged. Shown here is the radioactively contaminated sewer line being plugged 
11. Asbestos abatement/shower trailer setup at entrance to Room 103 of CFA-669 ....... 19

12. Asbestos barriers constructed before the start of asbestos removal $\ldots \ldots \ldots \ldots \ldots \ldots \ldots .20$

13. Boxes of radioactively contaminated waste were temporarily stored until they could

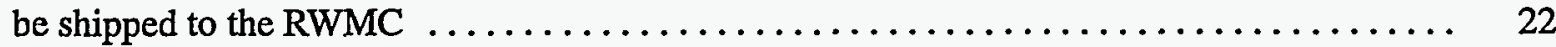

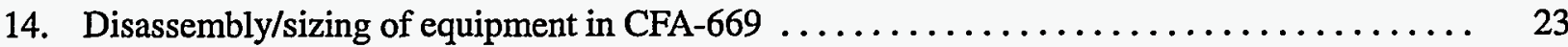

15. Sizing of radiologically contaminated equipment in CFA- $669 \ldots \ldots \ldots \ldots \ldots \ldots \ldots \ldots$

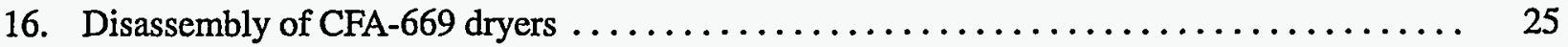

17. All electric motors were disassembled and inspected for hazardous waste before they

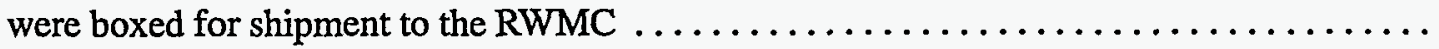

18. The Gantry crane was used to place heavy items into hot-waste boxes. A pallet dolly on each end of the box was used to move the box inside the building $\ldots \ldots \ldots \ldots \ldots \ldots$

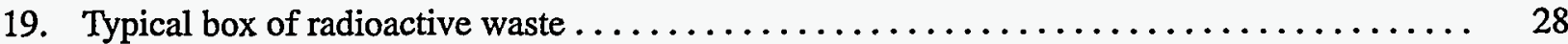

20. Asbestos abatement/shower trailer was set up at entrance to Room 110, the boiler room ..... 29

21. Room 110 (boiler room) after removal of asbestos $\ldots \ldots \ldots \ldots \ldots \ldots \ldots \ldots \ldots \ldots \ldots$

22. CFA- 669 boiler being rigged for hoisting $\ldots \ldots \ldots \ldots \ldots \ldots \ldots \ldots \ldots \ldots \ldots \ldots \ldots \ldots \ldots \ldots$

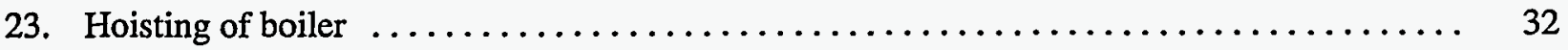

24. Placing the boiler on a flatbed trailer for shipment to CFA excess yard $\ldots \ldots \ldots \ldots \ldots$

25. A localized spot of radiological contamination was detected on the concrete floor beneath

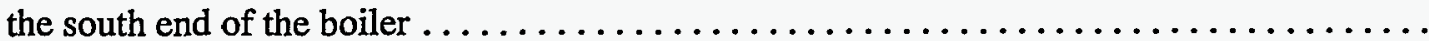

26. Room 109 after concrete scabbling. The portable cubicle was used to control airborne

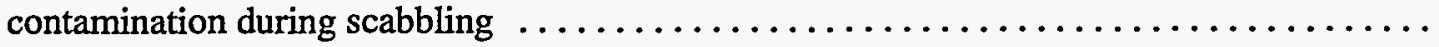

27. Liquid waste drain trench after scabbling. Decontamination of the trench could not be

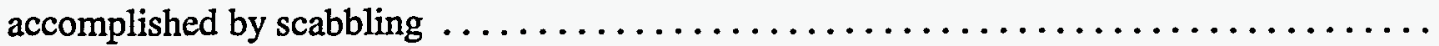

28. The trench in Room 108 was covered with steel plate and sealed with construction

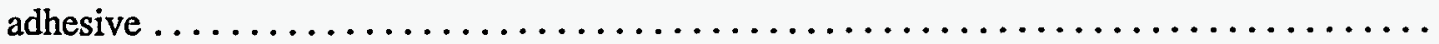

29. Five special boxes were built and used to contain contaminated filter units from the roof of CFA-669

30. Loose contamination was removed from the interior of CFA- 669 by brushing and

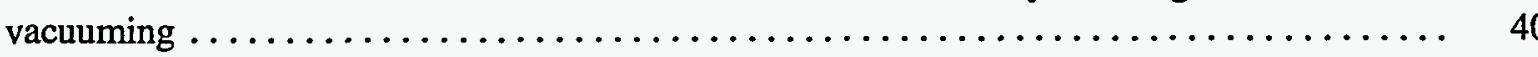

31. Surveying for fixed contamination $\ldots \ldots \ldots \ldots \ldots \ldots \ldots \ldots \ldots \ldots \ldots \ldots \ldots \ldots \ldots \ldots \ldots \ldots \ldots$

32. Fall-protection rail was constructed before the roof was removed $\ldots \ldots \ldots \ldots \ldots \ldots$ 
33. Removal of roofing material from CFA-669 $\ldots \ldots \ldots \ldots \ldots \ldots \ldots \ldots \ldots \ldots \ldots \ldots$

34. Contaminated roofing material was boxed for disposal at the RWMC $\ldots \ldots \ldots \ldots$

35. CFA-669 roof panels after roofing material was removed $\ldots \ldots \ldots \ldots \ldots \ldots \ldots \ldots \ldots$

36. Roof panels were lowered to the ground for radiological surveying $\ldots \ldots \ldots \ldots \ldots \ldots$

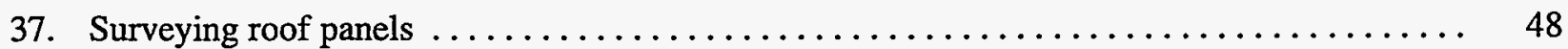

38. Roof panels were loaded onto a truck to be transported to the CFA landfill for disposal .... 49

39. Instrument used to perform the final survey of the floor of CFA- $669 \ldots \ldots \ldots \ldots \ldots$

40. Dismantling interior walls to segregate concrete blocks containing internal

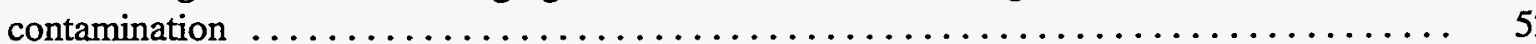

41. Concrete processor demolishing uncontaminated concrete walls to access bottom row of

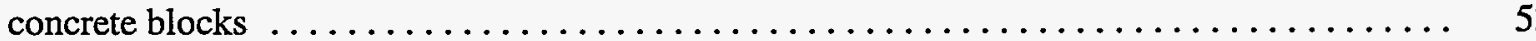

42. The bottom row of concrete blocks was removed by hand and surveyed for inaccessible

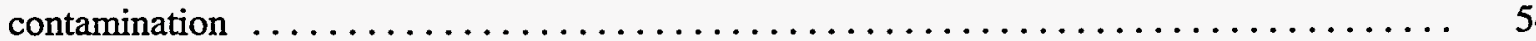

43. Contaminated soil being removed from beneath the concrete trench in Room $108 \ldots \ldots \ldots .55$

44. Wooden roof beams being placed on ground for surveying $\ldots \ldots \ldots \ldots \ldots \ldots \ldots \ldots$

45. Tractor-mounted concrete shear shown removing concrete footing $\ldots \ldots \ldots \ldots \ldots \ldots \ldots$

46. The water valve remaining after removal of the pipe section between the valve and

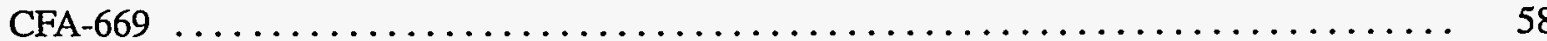

47. Contaminated liquid waste drain line from CFA $-669 \ldots \ldots \ldots \ldots \ldots \ldots \ldots \ldots \ldots$

48. Contaminated soil beneath and adjacent to the 8 -in. concrete drain pipe is being removed

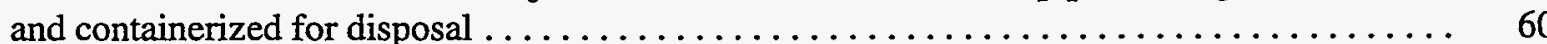

49. Topsoil was hauled to the CFA- 669 site and graded in preparation for hydroseeding $\ldots \ldots \ldots 62$

50. Following grading of the CFA- 669 site, the area was fertilized and hydroseeded $\ldots \ldots \ldots 63$

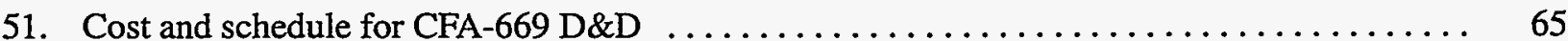

52. A comparison of CFA- 669 "before" and "after" completion of D\&D . . . . . . . . . 70 TABLES

1. General body field (GBF) and contact measurements in rooms and on roof of CFA-669

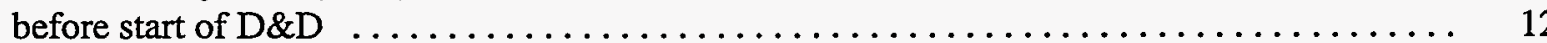

2. Pre-D\&D radiological survey results of beta-gamma contamination in CFA-669 ........ 13 


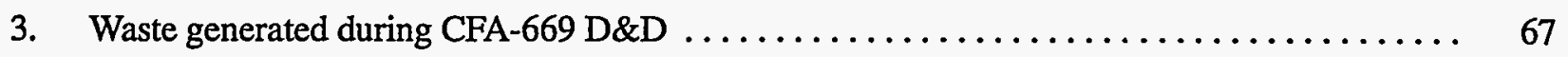

4. Recycled items and material from CFA-669 D\&D ..................... 67

5. Results of Phase I gamma spectrum analyses $\ldots \ldots \ldots \ldots \ldots \ldots \ldots \ldots \ldots \ldots \ldots \ldots$

6. Results of Phase I strontium-90 (Sr-90) and alpha spectrum analyses (pCi/g) $\ldots \ldots \ldots \ldots$

7. Results of Phase $I I$ gamma spectrum analysis $\ldots \ldots \ldots \ldots \ldots \ldots \ldots \ldots \ldots \ldots \ldots \ldots$

8. Results of Phase II Sr-90 and alpha spectrum analyses $(\mathrm{pCi} / \mathrm{g}) \ldots \ldots \ldots \ldots \ldots \ldots \ldots$ 


\section{ACRONYMS AND ABBREVIATIONS}

\begin{tabular}{|c|c|c|c|}
\hline $\mathrm{ACM}$ & asbestos-containing material & mrem & millirem \\
\hline $\mathrm{Am}$ & americium & $\mathrm{Nb}$ & niobium \\
\hline ASAP & $\begin{array}{l}\text { abbreviated sampling and analysis } \\
\text { plan }\end{array}$ & NEPA & National Environmental Policy Act \\
\hline CFA & Central Facilities Area & ORR & operational readiness review \\
\hline $\mathrm{Cm}$ & cadmium & OSHA & Occupational Safety and Health Act \\
\hline Co & cobalt & PCBs & polychlorinated biphenyls \\
\hline cpm & counts per minute & $\mathrm{pCi}$ & picocurie \\
\hline Cs & cesium & PPE & personal protective equipment \\
\hline $\mathrm{CX}$ & categorical exclusion & $\mathrm{Pu}$ & plutonium \\
\hline$D \& D$ & decontamination and dismantlement & RESRAD & residual radioactivity computer code \\
\hline DOE-ID & $\begin{array}{l}\text { U.S. Department of Energy Idaho } \\
\text { Operations Office }\end{array}$ & RMA & radiological material area \\
\hline dpm & disintegrations per minute & RWMC & $\begin{array}{l}\text { Radioactive Waste Management } \\
\text { Complex }\end{array}$ \\
\hline $\mathrm{EC}$ & environmental checklist & SAR & Safety Analysis Report \\
\hline Eu & europium & $\mathrm{Sb}$ & antimony \\
\hline g & gram & $\mathrm{Sr}$ & strontium \\
\hline HEPA & $\begin{array}{l}\text { general body field } \\
\text { high-efficiency particulate air }\end{array}$ & TCLP & $\begin{array}{l}\text { Toxicity Characteristic Leaching } \\
\text { Procedure }\end{array}$ \\
\hline $\mathrm{Hg}$ & mercury & Th & thorium \\
\hline HSP & Health and Safety Plan & TLDs & thermoluminescent dosimeters \\
\hline $\mathrm{HV}$ & heating and ventilation & $\mathrm{U}$ & uranium \\
\hline HWSF & Hazardous Waste Storage Facility & VOA & volatile organic analysis \\
\hline INEL & $\begin{array}{l}\text { Idaho National Engineering } \\
\text { Laboratory }\end{array}$ & WERF & $\begin{array}{l}\text { Waste Experimental Reduction } \\
\text { Facility }\end{array}$ \\
\hline
\end{tabular}




\section{FINAL REPORT \\ DECONTAMINATION AND DISMANTLEMENT \\ OF THE OLD HOT LAUNDRY, CFA-669}

\section{INTRODUCTION}

This final report describes the tasks performed to decontaminate and dismantle the old hot laundry, CFA-669, located at the Idaho National Engineering Laboratory (INEL) Central Facilities Area (CFA). This final report also describes the facility and site both before and after decontamination and dismantlement (D\&D) and identifies six significant lessons learned, project cost and duration, and waste volume generated.
Project objectives were to prevent future environmental contamination, possible public or INEL personnel exposure to radiation or hazardous materials, and to release the site for unrestricted use. These objectives were met by removing all hazardous and radiologically contaminated material from the facility, removing the building, foundation, and underground piping, and restoring the site to its original condition. 


\section{FACILITY DESCRIPTION BEFORE D\&D}

The CFA-669 hot laundry was located at the INEL CFA. The location of the INEL within the State of Idaho and the location of the CFA within the INEL are shown in Figure 1. The relative location of CFA-669 within the CFA is shown in Figure 2.

\subsection{Physical Description}

2.1.1 Building Exterior. CFA-669 was a single-story structure constructed of concrete block and a concrete slab floor. The original exterior, viewed from several vantage points, is shown in Figures 3 through 5 . The highefficiency particulate air (HEPA) filter system and the heating and ventilation (HV) system were located on the roof of the building. There were four roof runoff drain pipes. Three of the roof drain pipes were located on the north side of the building; the fourth was located on the east side. A 15,000-gal fuel oil tank, originally buried underground northwest of the boiler room, was removed under the direction of the EG\&G Idaho Tank Management program on October 22, 1990. The surrounding soil was analyzed in 1990 and determined not to be contaminated from the contents (\#2 diesel fuel) of the tank.

CFA-669 was constructed in 1950 to serve as the "hot" and "cold" laundry for INEL site contractors. In the mid-1970s, a new laundry facility was proposed and subsequently built because CFA-669 did not comply with required standards. The use of CFA-669 was discontinued in 1981 after the boiler exploded.

2.1.2 Building Interior. CFA-669 had nearly $4500 \mathrm{ft}^{2}$ of floor space. The original plan is shown in Figure 6.

- Rooms 101, 102, and 103. Room 101 was used as a lunch area. Room 102 was the main entry to the laundry room from the outside. Room 103 contained a hot-water heater. These rooms had no traps, floor drains, or pipe cleanouts.
- Rooms 104 and 105. These rooms were used as the men's and women's restrooms, respectively. Each room housed showers and contained floor and shower drains and sink traps.

- Room 106. This room was a storage area and contained no traps, cleanouts, or drains. There were some wood shelves in the room.

- Room 107. This room served as the shipping and receiving area and had no traps, cleanouts, or drains. The room opened into a hallway where a recessed scale in the floor was used to weigh laundry bundles.

- Room 108. This was the main laundry area. The room housed five dryers, two washers, and an extractor. The extractor removed excess water from laundry using centrifugal force. The main HV system was suspended from the ceiling. A drain trench was located near the washers. The drain pipes that led from the building were beneath the floor. Figure 7 is a photograph of Room 108 showing washers and dryers before the start of D\&D.

- Room 109. This room was used as a sorting and folding area. There were no drains, traps, or cleanouts in this area.

- Room 110. This was the boiler room. The boiler and assorted piping were in the room. The boiler was damaged from an earlier explosion. A drain trench was located in the room. A chimney cleanout was located on the outside of the north wall. An interior view of the boiler room before the start of $D \& D$ is shown in Figure 8.

- Room 111. This was a small room that contained a drinking fountain and a cleanout drain next to the fountain. 
ARA = Auxillary Reactor Area

CFA $=$ Conlral Facility Area

EQR 1 = Experimental Breeder Resctor 1 (Historical Monument)

ICPP = Idaho Chemical Processing Plant

IET = Initial Engineering Test

LOFT $=$ Loss-ol-Fuid Test

NRF $=$ Naval Reactor Facility

PEF/SPERT = Power Burs! Facility/Special Power Excursion Reactor Test

RWMC = Radioactive Waste Management Complex

SMC = Spocial Marulacturing Capability

STF = Safory Training Faciliay

TAA $=$ Tost Reactor Area

TSF $=$ Technical Support Facility

WRATF $=$ Water Reactor Reseerch Test Facility

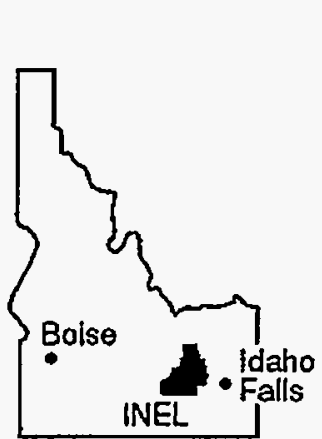

To Arco illity 


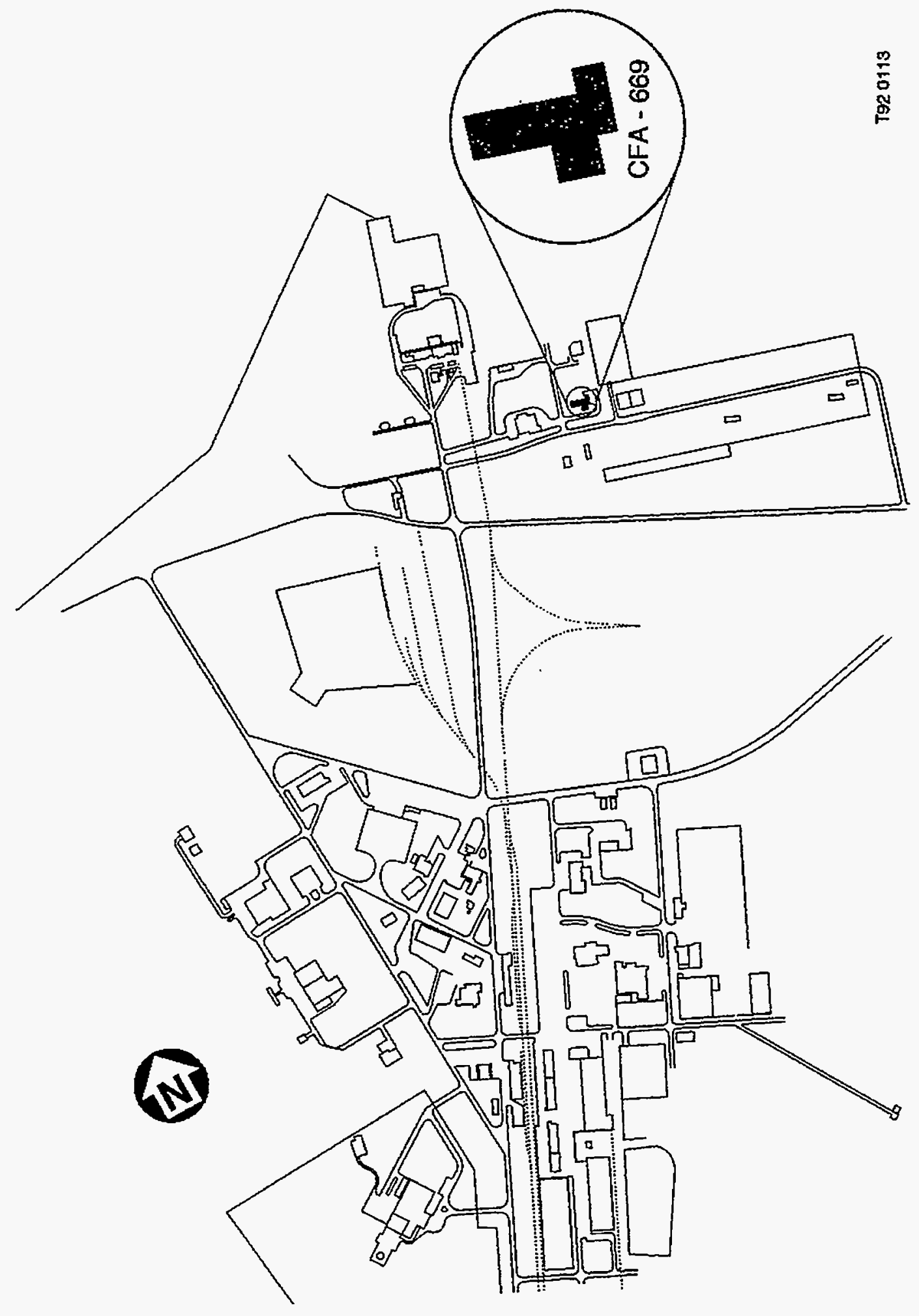

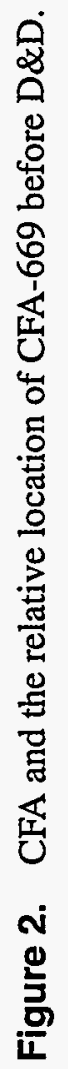




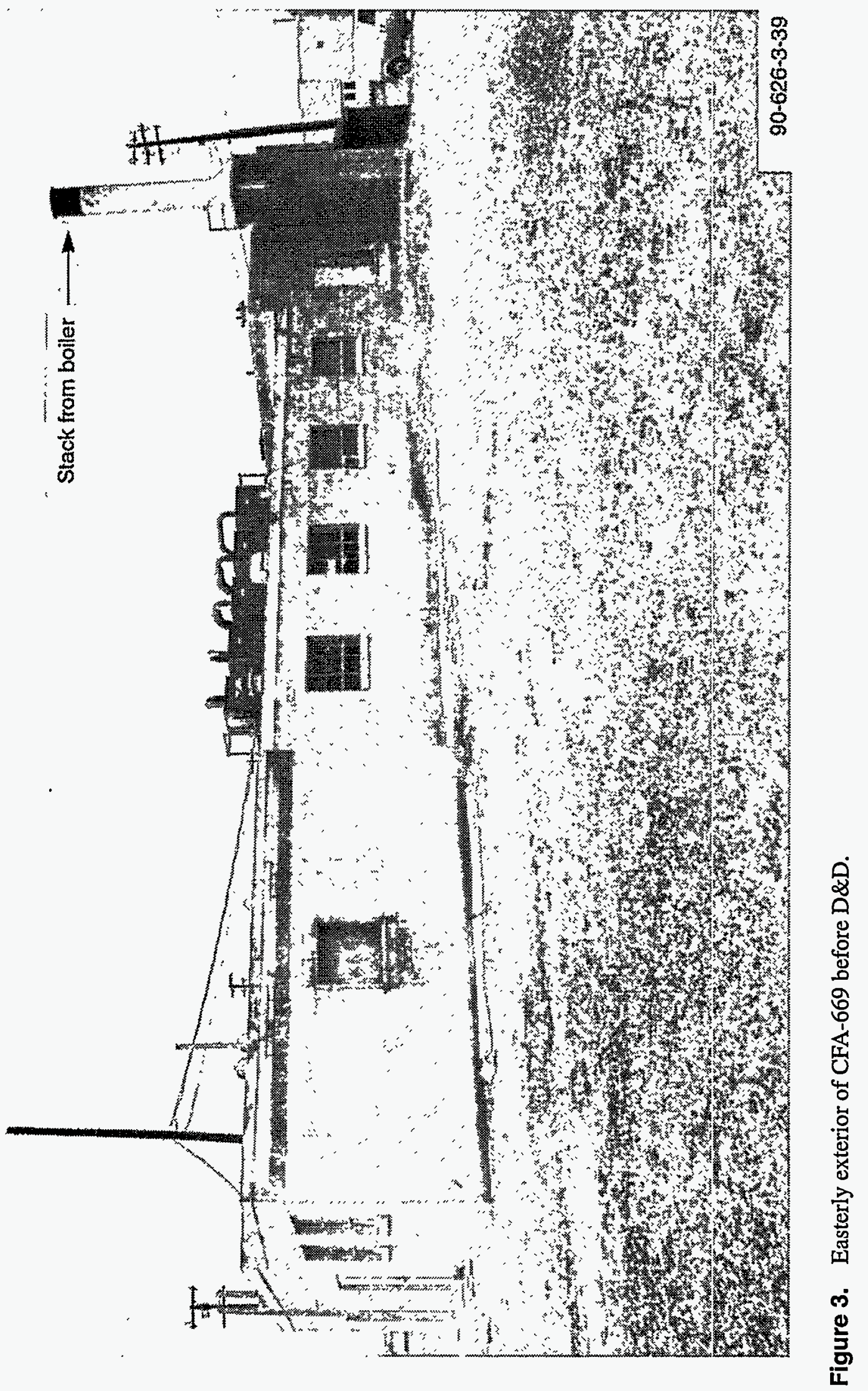



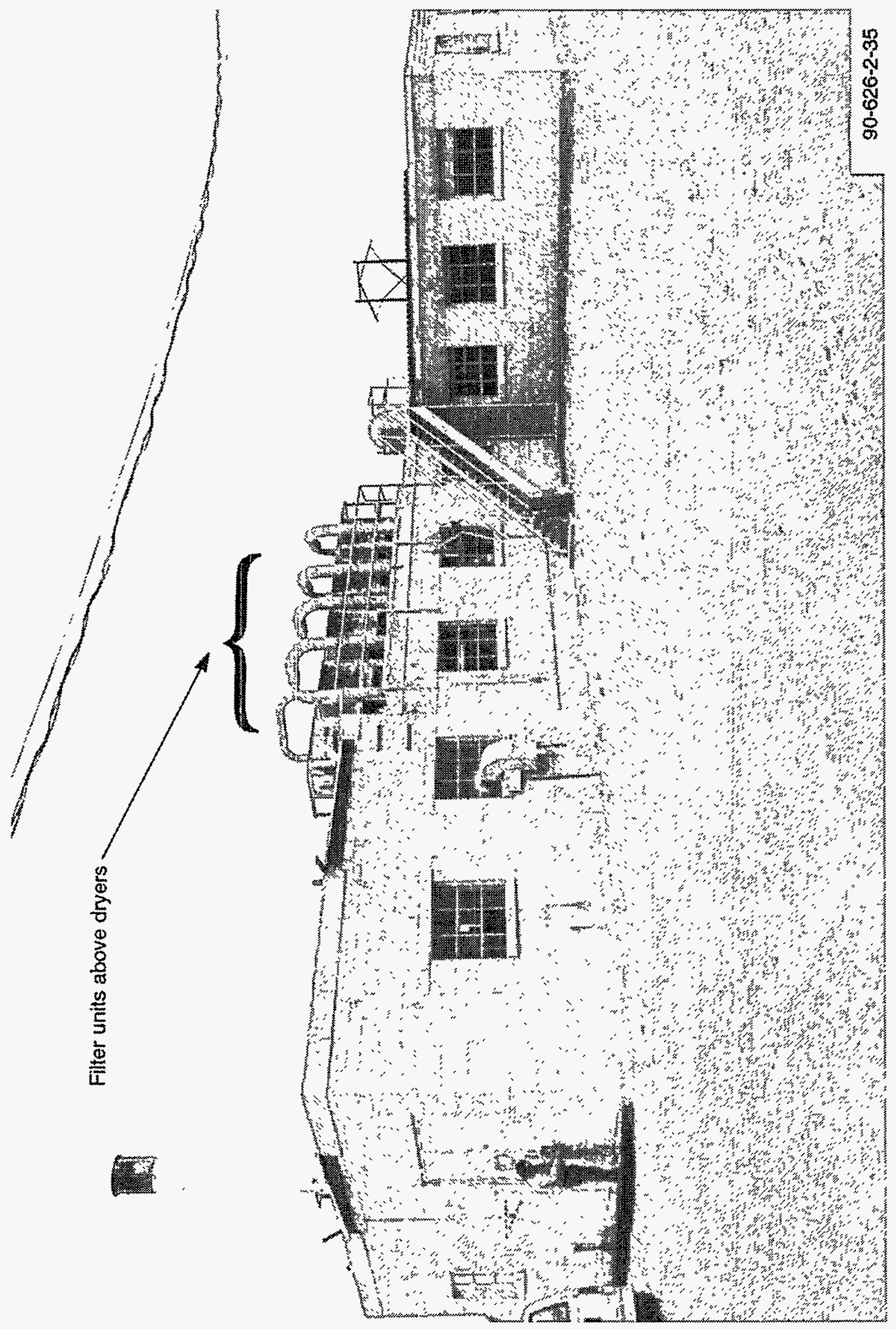

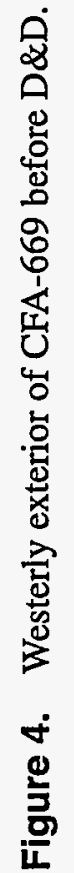




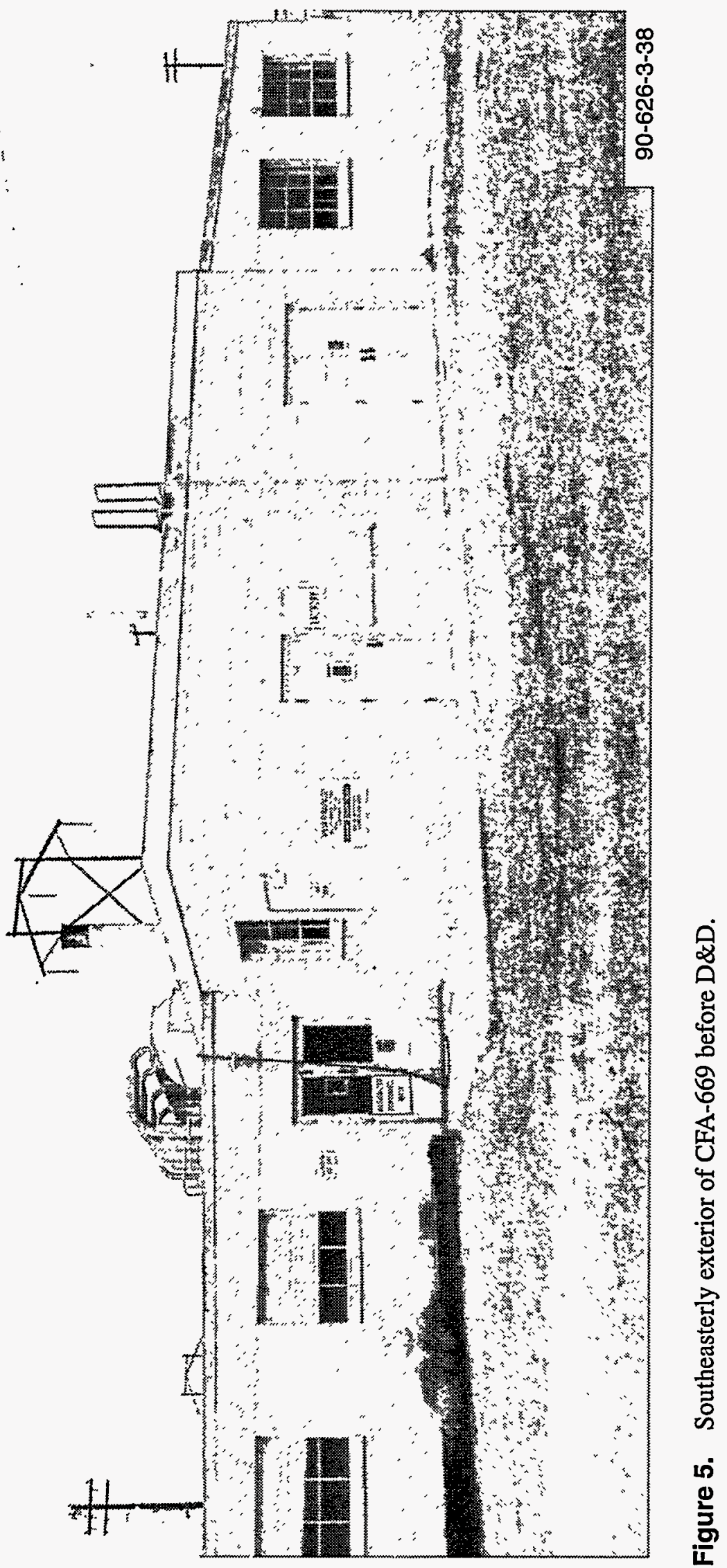




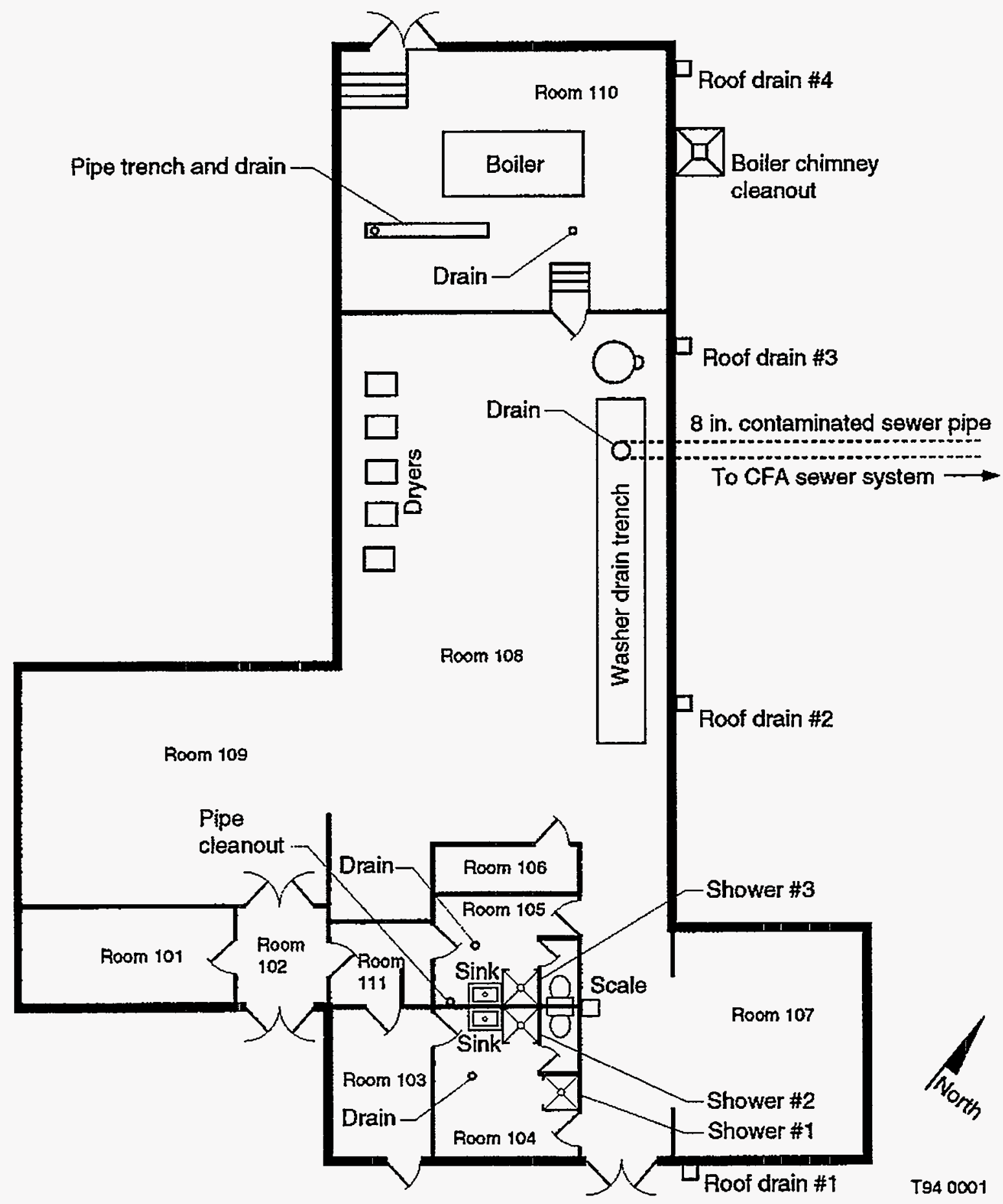

Figure 6. Original floor plan of CFA-669. 


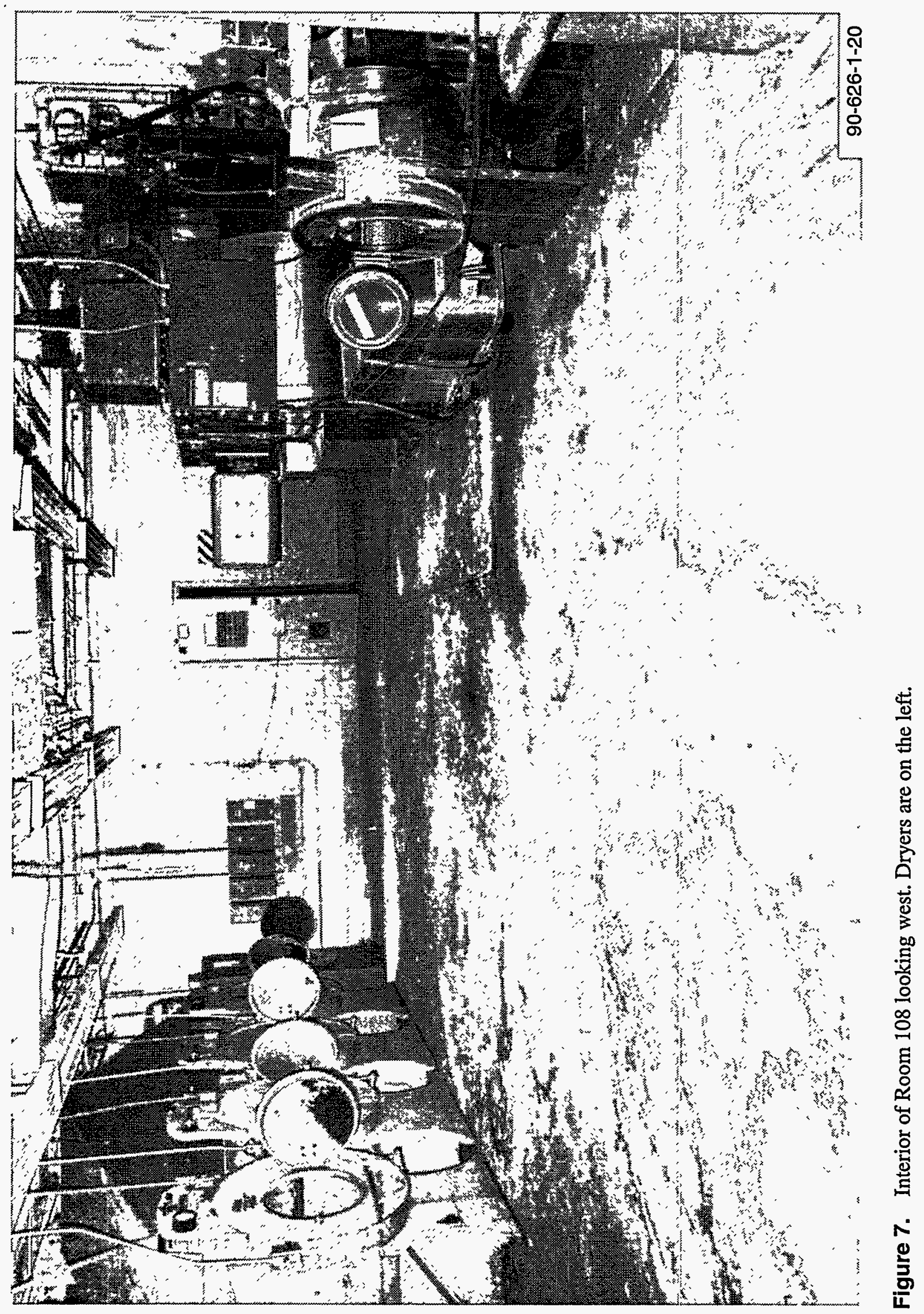




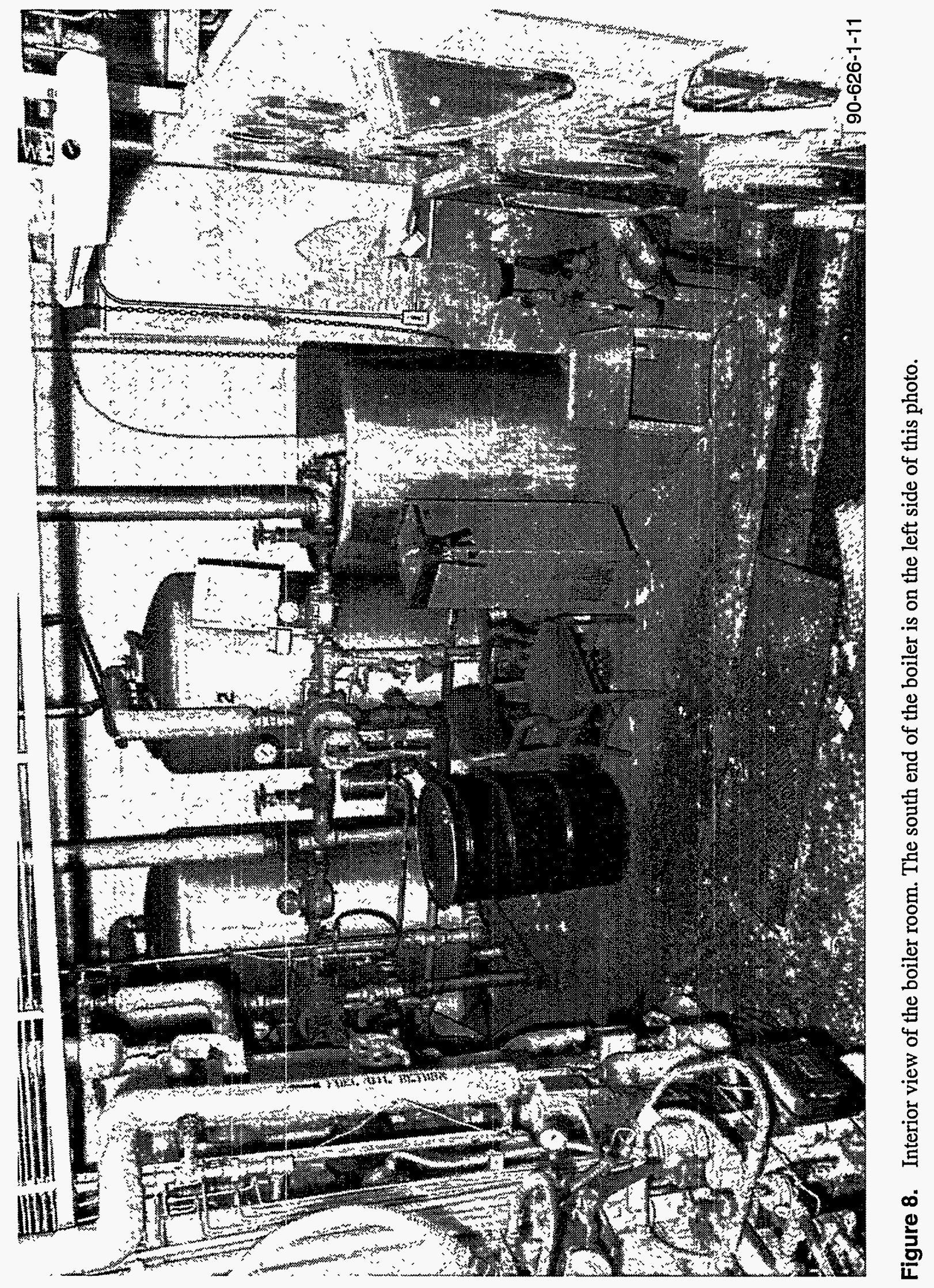


2.1.3 Underground Piping. Underground piping consisted of the following:

- 8-in. concrete pipe that drained the concrete trench in Room 108. This radiologically contaminated pipe exited the building on the north side.

- 8-in. concrete sanitary sewer pipe that exited the building near the southeast corner.

- 4-in. water line that supplied the building from the main water line on the northwest side of CFA- 669 .

- A 2-in. steam line that exited the boiler room on the north wall and connected to a steam line in a manhole about $75 \mathrm{ft}$ north of CFA-669. The steam line was not insulated with asbestos-containing material.

\subsection{Radiological Condition}

The pre-D\&D radiological characterization of CFA-669 is described and reported in Reference 1 ; however, the results are summarized in the following sections to generally indicate the extent and levels of radiological contamination in CFA- 669 before D\&D. This section also gives the radiological condition of areas of the CFA-669 facility that were not accessible during pre-D\&D characterization. The post-D\&D radiological condition is given in Section 7.

\subsubsection{Gross Alpha and Beta Contamina-} tion. Gross alpha concentrations in the 29 grab samples ranged from 6 to $310 \mathrm{pCi} / \mathrm{g}$. The locations where the 29 grab samples were collected are given in Reference 1. Gross beta measurements ranged from 6 to $15,000 \mathrm{pCi} / \mathrm{g}$. The highest concentrations of alpha and beta contamination were measured in samples taken from Room 108. In Room 108, gross alpha measurements ranged from 13 to $310 \mathrm{pCi} / \mathrm{g}$ and gross beta measurements ranged from 310 to $15,000 \mathrm{pCi} / \mathrm{g}$.

2.2.2 Gamma Contamination. The grab samples were analyzed by gamma spectrometry for specific gamma-emitting radionuclides. Radionuclides identified in the samples were cobalt (Co)-60, cesium (Cs)-137, antimony (Sb)-125, europium (Eu)-152, Eu-154, and niobium (Nb)-94. The highest radionuclide activity was measured in samples from Room 108. The sample from the extractor drain pipe measured Co-60 activity of $10,200 \mathrm{pCi} / \mathrm{g}, \mathrm{Cs}-137$ activity of $452 \mathrm{pCi} / \mathrm{g}$, and Nb-94 activity of $301 \mathrm{pCi} / \mathrm{g}$. Radionuclides of Co-60 (up to $8,000 \mathrm{pCi} / \mathrm{g}$ ) and Cs-137 (up to $398 \mathrm{pCi} / \mathrm{g}$ ) were measured in the dryer cleanouts.

\subsubsection{Other Radiologicál Measurements.} Smears, wipes, and direct scans were performed to further characterize the level of removable and fixed radioactive contamination in CFA-669.

2.2.3.1 Building Roof. The beta-gamma radiation field in the HEPA filter system on the roof at the west end of the building measured 300-2,000 counts per minute (cpm) above background (removable and fixed). In addition, fixed contamination was discovered in the roofing material during its removal. This contamination was up to several hundred cpm beta-gamma, generally imbedded in the roofing material.

2.2.3.2 Building Interior. The pre-D\&D survey results are summarized in Table 1.

All smears collected in CFA- 669 before D\&D measured less than 200 disintegrations per minute (dpm)/100 $\mathrm{cm}^{2}$ beta-gamma and less than $20 \mathrm{dpm} / 100 \mathrm{~cm}^{2}$ alpha above background. Wipes of $\mathrm{HV}$ vents indicated radiological contamination of vents in Rooms 101, 103, 104, 107, and 108. Floor wipes indicated contamination in Rooms 107, 108, and 109. Floor wipes in the other rooms indicated no radioactive contamination. However, smears collected on the top surface of pipes and ledges during $D \& D$ revealed removable contamination above $200 \mathrm{dpm} / 100 \mathrm{~cm}^{2}$ betagamma in all rooms except the boiler room.

The pre-D\&D results of the wipes and contact radiation measurements are summarized in Table 2. Contact radiation measurements of the floor surface in Rooms 107 and 108 revealed 
Table 1. General body field (GBF) and contact measurements in rooms and on roof of CFA-669 before start of D\&D.

\begin{tabular}{|c|c|}
\hline Area & Beta-gamma measurements \\
\hline Roof & $<0.1 \mathrm{mrem} / \mathrm{h}(\mathrm{GBF})$ \\
\hline Room 101 & $<0.1 \mathrm{mrem} / \mathrm{h}(\mathrm{GBF})$ \\
\hline Room 102 & $<0.1 \mathrm{mrem} / \mathrm{h}(\mathrm{GBF})$ \\
\hline Room 103 & $<0.1 \mathrm{mrem} / \mathrm{h}(\mathrm{GBF})$ \\
\hline Room 104 & $<0.1 \mathrm{mrem} / \mathrm{h}(\mathrm{GBF})$ \\
\hline Room 105 & $<0.1 \mathrm{mrem} / \mathrm{h}(\mathrm{GBF})$ \\
\hline Room 106 & $<0.1 \mathrm{mrem} / \mathrm{h}(\mathrm{GBF})$ \\
\hline Room 107 & $<0.1 \mathrm{mrem} / \mathrm{h}(\mathrm{GBF})$ \\
\hline \multirow[t]{9}{*}{ Room 108} & Trench-southeast end \\
\hline & $\begin{array}{l}10 \mathrm{mrem} / \mathrm{h} \text { at contact; } 5 \mathrm{mrem} / \mathrm{h} \text { at } 3 \mathrm{ft} \\
\text { Trench-northwest end }\end{array}$ \\
\hline & $\begin{array}{l}100 \mathrm{mrem} / \mathrm{h} \text { at contact; } 10 \mathrm{mrem} / \mathrm{h} \text { at } 3 \mathrm{ft} \\
\text { Drain-north corner of room }\end{array}$ \\
\hline & $\begin{array}{l}3 \mathrm{mrem} / \mathrm{h} \text { at bottom of hole; }<0.5 \mathrm{mrem} \text { at } 3 \mathrm{ft} \\
\text { Inside dryer } 5-<0.1 \mathrm{mrem} / \mathrm{h} \text { at contact }\end{array}$ \\
\hline & $\begin{array}{l}<0.1 \mathrm{mrem} / \mathrm{h} \text { at } 3 \mathrm{ft} \\
\text { Inside dryer } 4-0.2 \mathrm{mrem} / \mathrm{h} \text { at contact }\end{array}$ \\
\hline & $\begin{array}{l}<0.1 \mathrm{mrem} / \mathrm{h} \text { at } 3 \mathrm{ft} \\
\text { Inside dryer } 3<0.1 \mathrm{mrem} / \mathrm{h} \text { at contact }\end{array}$ \\
\hline & $\begin{array}{l}<0.1 \mathrm{mrem} / \mathrm{h} \text { at } 3 \mathrm{ft} \\
\text { Inside dryer } 2-5 \mathrm{mrem} / \mathrm{h} \text { at contact }\end{array}$ \\
\hline & $\begin{array}{l}<0.1 \mathrm{mrem} / \mathrm{h} \text { at } 3 \mathrm{ft} \\
\text { Inside dryer } 1-4 \mathrm{mrem} / \mathrm{h} \text { at contact }\end{array}$ \\
\hline & $\begin{array}{l}<0.1 \mathrm{mrem} / \mathrm{h} \text { at } 3 \mathrm{ft} \\
\text { Wall behind washers-approximately } 5 \mathrm{mrem} / \mathrm{h} \\
\text { Wall behind dryers- }<0.5 \mathrm{mrem} / \mathrm{h} \\
\text { In middle of room- }<0.5 \mathrm{mrem} / \mathrm{h}(\mathrm{GBF})\end{array}$ \\
\hline Room 109 & $<0.1 \mathrm{mrem} / \mathrm{h}(\mathrm{GBF})$ \\
\hline Room 110 & $<0.1 \mathrm{mrem} / \mathrm{h}(\mathrm{GBF})$ \\
\hline Room 111 & $<0.1 \mathrm{mrem} / \mathrm{h}(\mathrm{GBF})$ \\
\hline
\end{tabular}

localized areas of beta-gamma contamination ranging from 1,000 to $46,000 \mathrm{cpm}$ above background beta-gamma. During $\mathrm{D} \& \mathrm{D}$, an area in the concrete trench in Room 108 measured $50 \mathrm{mrem} / \mathrm{h}$ beta-gamma at contact.

2.2.3.3 Soil. Eight soil samples were collected at four locations outside CFA-669 near the roof runoff drain pipes and analyzed for gross alpha, beta, and gamma spectrum. A surface sam- ple and subsurface sample at a depth of $2 \mathrm{ft}$ were collected at each of the four locations.

The gamma-emitting radionuclides identified were Cs-137 and Co-60. The highest specific activity for Cs-137 and Co-60 in all the soil samples was $2.9 \mathrm{pCi} / \mathrm{g}$ and $2.7 \mathrm{pCi} / \mathrm{g}$, respectively, and was detected in surface samples.

The highest concentration of gross alpha detected in the soil samples was $55 \mathrm{pCi} / \mathrm{g}$ in a 
subsurface sample. The highest gross alpha concentration detected in a surface soil sample was $53 \mathrm{pCi} / \mathrm{g}$.

The highest concentration of gross beta in the pre-D\&D soil samples was $34 \mathrm{pCi} / \mathrm{g}$. During excavation of the 8-in. concrete pipe that drained liquid waste from Room 108, the soil beneath the pipe was found to be contaminated to depths down to $2 \mathrm{ft}$.

2.2.3.4 Underground Piping. The underground piping was not characterized before the start of D\&D. During D\&D, the piping was found to be uncontaminated, except for the 8-in. concrete pipe that drained liquid waste from Room 108. The interior of this pipe measured up to $40 \mathrm{mrem} / \mathrm{h}$ beta-gamma when the pipe was cut and plugged in December 1992.

\subsection{Hazardous Chemical Condition}

The pre-D\&D chemical characterization of CFA-669 is described and reported in Reference 1. A summary of the characterization results is given in this section. During $\mathrm{D} \& \mathrm{D}$, representative samples of radioactive waste were sampled and analyzed for Toxicity Characteristic Leaching Procedure (TCLP) metals. The results indicated that there was no mixed waste. The hazardous chemical condition of the site after D\&D is reported in Section 7.

Mercury $(\mathrm{Hg})$ concentrations of 163 and $532 \mu \mathrm{g} / \mathrm{L}$ were measured in the pipe cleanout and pipe trench in Room 110, respectively. The $\mathrm{Hg}$ measurements were flagged to indicate the spiked sample recovery and that the duplicate analyses were not within control limits. The maximum allowable TCLP concentration for $\mathrm{Hg}$ is $200 \mu \mathrm{g} / \mathrm{L}$ $(0.2 \mathrm{mg} / \mathrm{L})$. More than half the air samples taken in Room 110 indicated $\mathrm{Hg}$ levels greater than the Occupational Safety and Health Act (OSHA) exposure limit of $0.05 \mathrm{mg} / \mathrm{m}^{3}$. During D\&D, mercury-contaminated debris was removed from the boiler room and disposed of as hazardous waste.

Asbestos was identified in the building and roof. All equipment and material in the boiler room (Room 110) were covered with a fine, asbestosladen dust generated by the boiler explosion. The dust and equipment in Room 110 were not radioactively contaminated except for a few localized spots detected during D\&D. A roof material sample indicated that two of the three layers of roofing material contained asbestos. The roofing material (except Room 110) was disposed of as radioactively contaminated asbestos-containing material (ACM). 


\section{WORK PERFORMED}

This section describes the work performed during this project, from initial planning through post-D\&D characterization.

\subsection{Project Planning and Management}

The EG\&G Idaho, Inc., D\&D Projects Unit planned and managed this D\&D project.

\subsubsection{Preliminary Planning.}

- $\quad$ Prepared pre-D\&D Abbreviated Sampling and Analysis Plan (ASAP), Reference 2. The ASAP was based on history and process knowledge of CFA-669 and was finalized and issued in March 1991.

- Performed pre-D\&D characterization. The pre-D\&D characterization consisted of direct radiation measurements and collection and analyses of samples collected at CFA-669. The pre-D\&D characterization was performed in accordance with the pre-D\&D ASAP and was completed in September 1991.

- Prepared the Characterization and Decision Analysis Report, Reference 1.

The results of the pre-D\&D characterization were reported in the Characterization and Decision Analysis Report. In addition, a detailed decision analysis was performed to consider three D\&D alternatives. Those alternatives are listed below:

- Do nothing. Continue surveillance and maintenance of the CFA-669 Facility.

- Partial dismantlement and renovation. Decontaminate, repair, and release the facility for unrestricted use.

- Total dismantlement. Decontaminate and dismantle CFA-669, excavate underground piping, remove contaminated soil, and restore the area to its original condition.

To protect the public and INEL personnel, the main criterion in selecting an alternative was removal of radiological and hazardous waste.

Factors considered during the decision process were:

- $\quad$ Reuse of facility and materials

- $\quad$ Cost and schedule

- Volumes of waste

- Hazards to D\&ED workers

- Short-term impact on other INEL personnel and operations

- Long-term impact on public safety

- Advantages and disadvantages of each alternative.

After considering the above factors, the preferred D\&D alternative was total dismantlement. This alternative was selected after obtaining U.S. Department of Energy Idaho Operations Office (DOE-ID) concurrence.

3.1.2 Final Planning. This section describes the final planning process following the decision to totally dismantle CFA-669.

- $\quad$ Prepared the D\&D plan, Reference 3. The D\&D plan described tasks and specified requirements to remove radiological and hazardous contamination, demolish the building, excavate underground piping, and restore the area to its original condition. The D\&D plan was first issued in September 1992. Revision 1 was issued in November 1992 to resolve findings during the Operational Readiness Review (ORR) conducted in October 1992.

- $\quad$ Prepared the Safety Analysis Report (SAR), Reference 4 . The SAR was prepared to 
assess the environmental, safety, and health hazards associated with the D\&D of CFA-669. The SAR was issued September 1992; Revision 1 was issued in February 1993 to clarify operational safety requirements.

- Prepared the Health and Safety Plan (HSP), Reference 5. The HSP was prepared to meet OSHA requirements in 29 CFR 1910.120, "Hazardous Waste Operations and Emergency Response." The HSP established the procedures and requirements necessary to minimize health and safety risks to persons performing D\&D of CFA-669.

Revision 0 of the HSP was issued May 1992. Revision 1 was prepared and issued November 1992 before the start of D\&D operations. Revision 1 was required in order to resolve October 1992 ORR findings. Revision 2 was issued November 1993 to clarify health and safety requirements.

- Prepared National Environmental Policy Act (NEPA) documentation. In compliance with NEPA requirements, an Environmental Checklist (EC), Form ID F 5440.1a, covering CFA-669 D\&D, was prepared and submitted to the EG\&G Idaho Environmental Assessment Unit. This EC was logged in as No. CFA-92-001, and it was determined by information provided within the EC that a Categorical Exclusion (CX) would be required under the new rule, 10 CFR 1021, which was finalized in June 1992.

The Environmental Assessment Unit prepared a CX determination and submitted it to DOE-ID in May 1992. DOE-ID approved the CX determination on July $21,1992$.

\subsection{D\&D Operations and Waste Disposal}

This section describes D\&D operations, from site facility preparation through excavation of the foundation and underground piping.
3.2.1 Site Facility Preparations. Prior to the start of interior decontamination, the site and facility were prepared for D\&D. Site preparation consisted of the following tasks:

- Erected an exclusion/safety fence around the project boundary. This 48 -in.-high orange plastic fence is shown in Figure 9 (This aerial photo was taken after the start of D\&D). "Danger" and "Keep Out" signs were installed on the fence prior to start of D\&D operations.

- Installed electrical power to the project including power pole, transformer, and electrical circuit breakers and outlet connectors.

- Isolated the building. This was accomplished by excavating, cutting, and plugging the two sanitary sewer lines, water line, and steam line. Figure 10 shows the plugging of the contaminated sewer line using an inflatable rubber plug.

- Installed drain plugs in all building drains.

- Locked and sealed door between Rooms 108 and 110 to prevent spread of contamination into Room 110.

- Installed an asbestos-abatement/shower trailer at the entrance to Room 103 and construction of an enclosure between the trailer and Room 103 (Figure 11).

- Installed zone partitions and asbestos barriers inside the building (Figure 12).

- Set up a radiological contamination exclusion zone with step-off pad in Room 103.

- Installed six electrical heaters inside CFA-669.

- Set up a project office trailer at the CFA-669 site (Figure 9).

3.2.2 Removal and Disposal of Contaminated Asbestos. The radiologically contaminated, asbestos-insulated piping in all the 


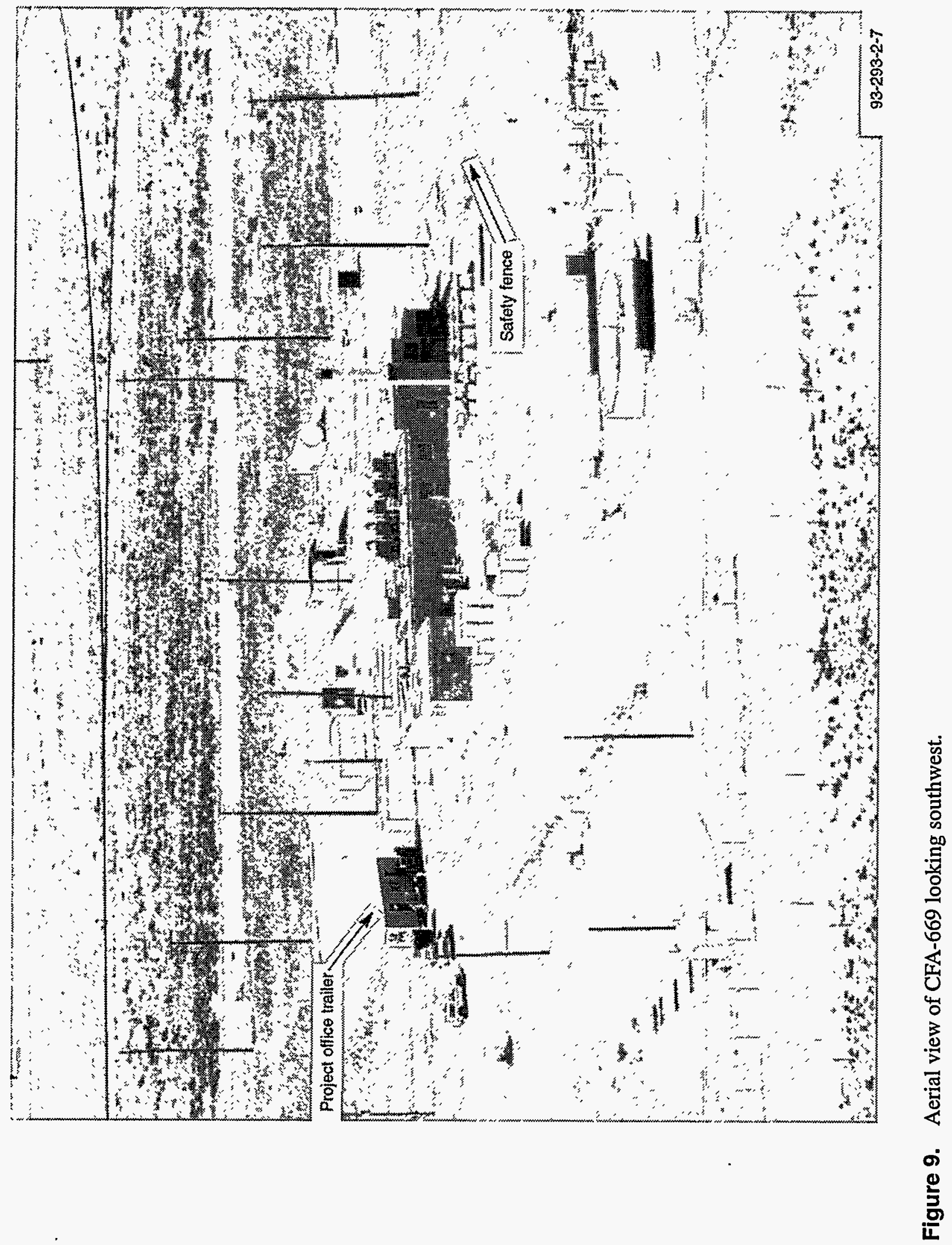




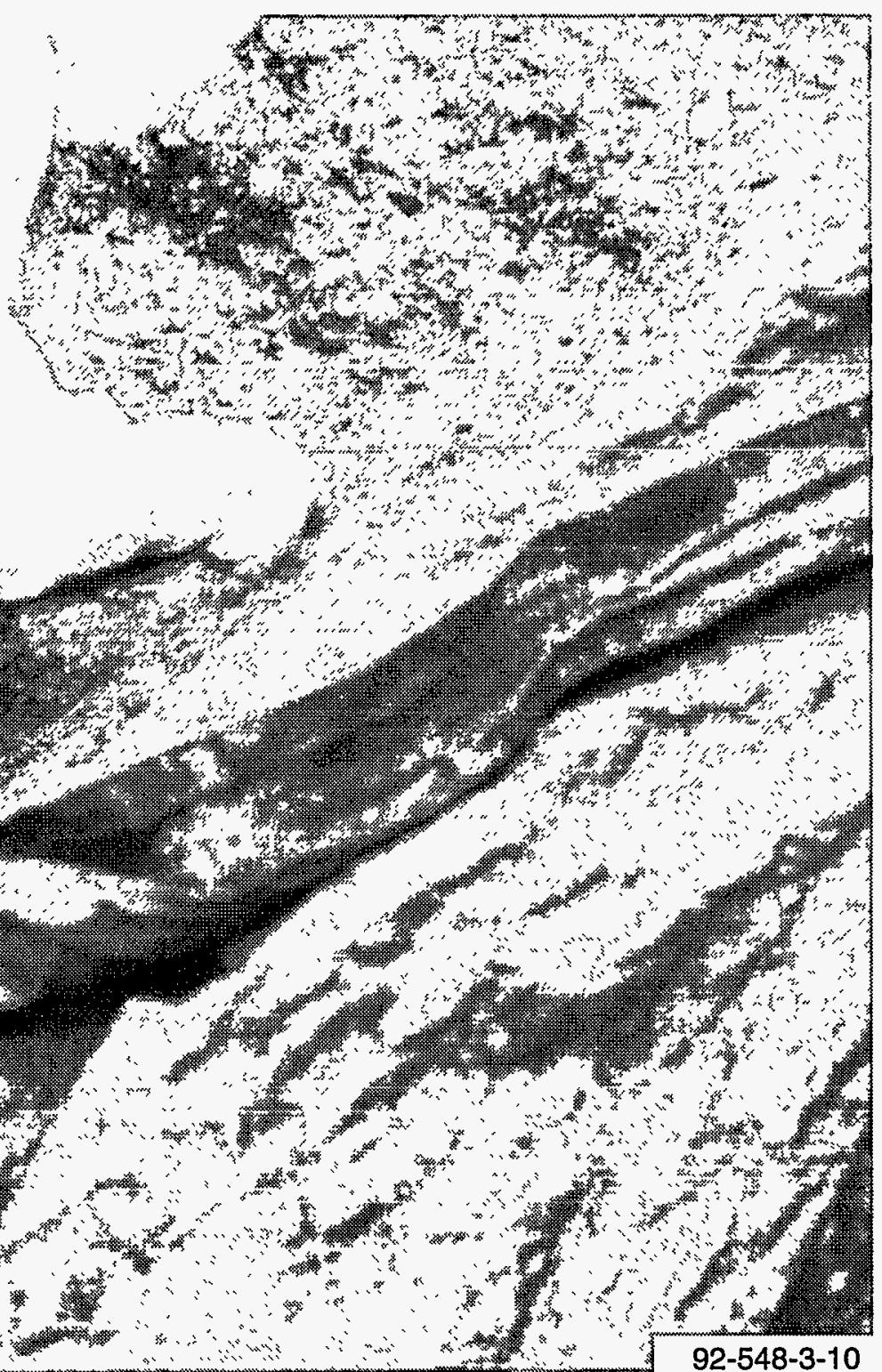

Figure 10. Two sanitary sewer lines were cut and plugged. Shown here is the radioactively contaminated sewer line being plugged. 


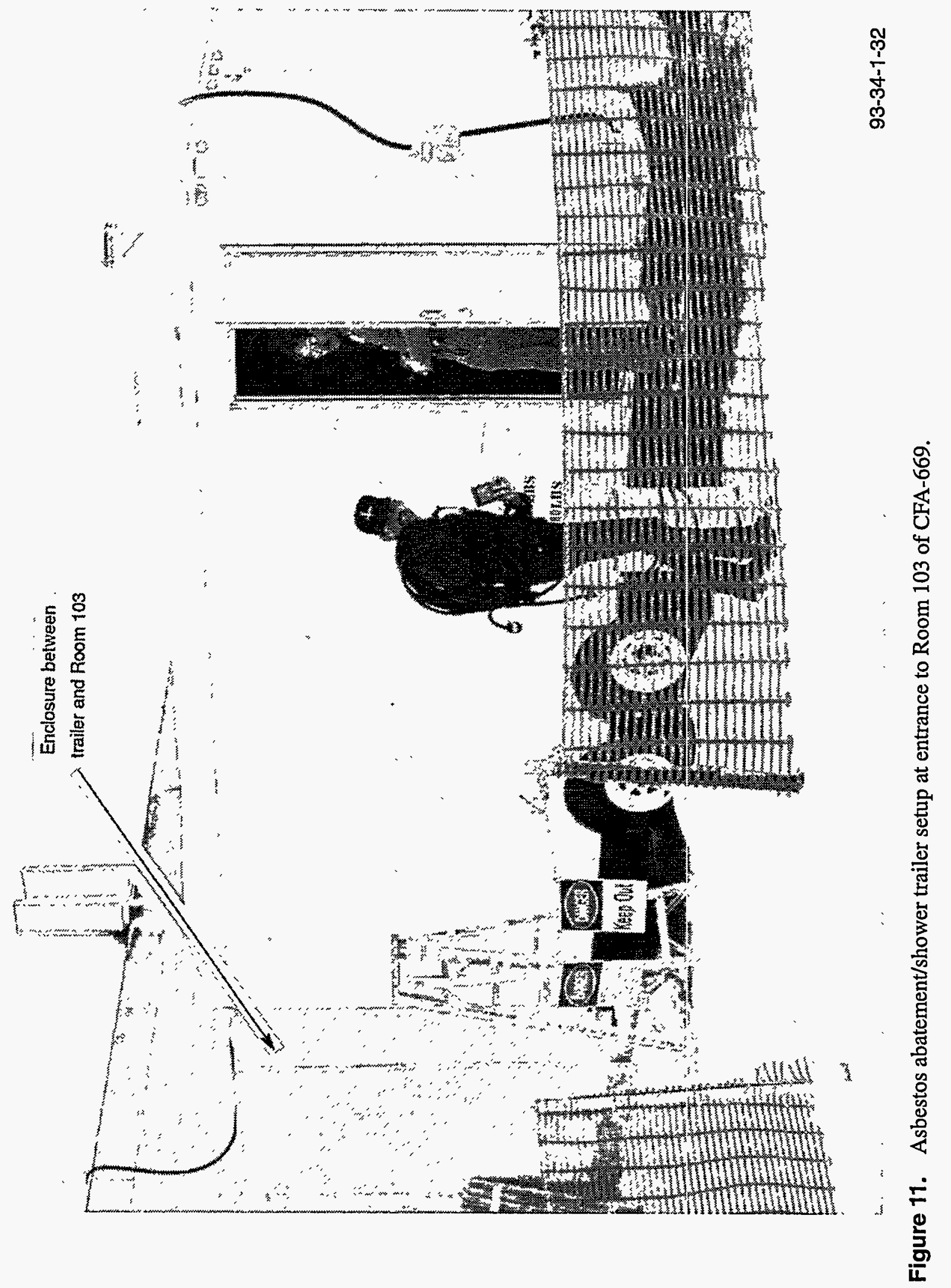




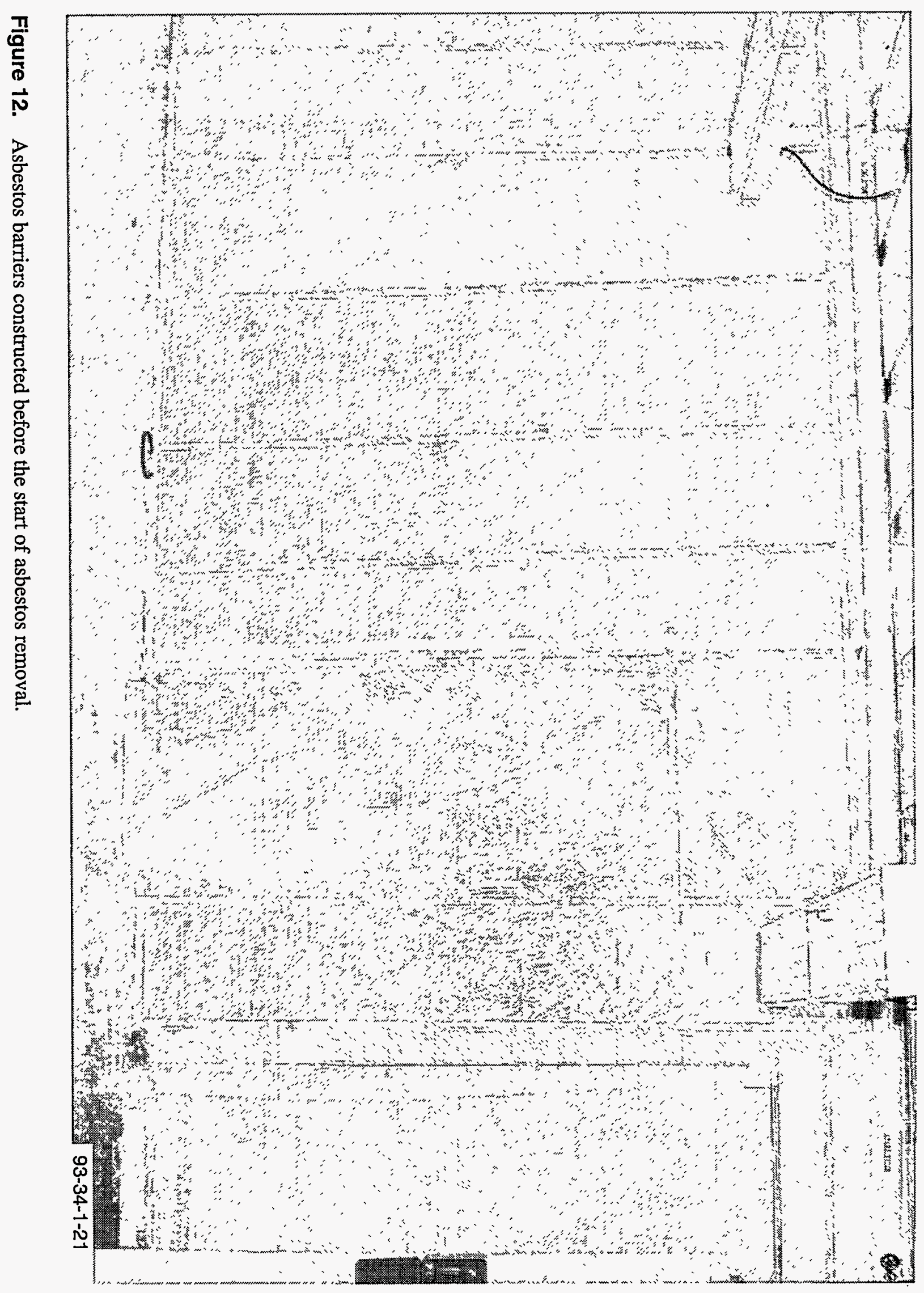


rooms (except the boiler room) was removed, bagged, and placed in 4- $\times 4-\times 8$-ft boxes for disposal at the RWMC. Removal of asbestos in the boiler room is discussed in Section 3.2.4. Boxes of radioactive waste were accumulated in a radiological material area (RMA) outside CFA-669 until shipment to the RWMC could be coordinated and approval-to-ship obtained from RWMC management (Figure 13). Boxes were moved into and out of the building using pallet dollies.

\subsubsection{Removal and Disposal of Contami-} nated Equipment. Most equipment inside CFA-669, except equipment in the boiler room, was radioactively contaminated. The contaminated equipment included washers, dryers, piping, $\mathrm{HV}$ ducting and components, electrical motors, conduits, electrical conductors, building fixtures, and other building components that could not be decontaminated and released as uncontaminated.

The contaminated equipment was sized using nibblers, saws, shears, or plasma-arc torch. Plasma-arc torch cutting was used only to size steel components that were too massive to cut mechanically. Figures 14 through 19 show removing, sizing, and boxing of contaminated equipment.

\subsubsection{Removal and Disposal of Asbestos and Mercury from Room 110 The asbestos-} abatement/shower trailer was moved from the entrance to Room 103 and installed at the entrance to Room 110, the boiler room (Figure 20).

Room 110 contained an asbestos-insulated boiler as well as large amounts of asbestosinsulated piping. The room also contained mercury-contaminated debris on the floor and in the drain trench.

The first task was to remove the mercurycontaminated debris to reduce the airborne concentration to levels that would allow using air-purifying respirators rather than air-supplied respirators.
Following removal of mercury-contaminated debris, the asbestos was removed, bagged, and placed in boxes for disposal at the CFA landfill. Figure 21 is a view of Room 110 following removal of the asbestos.

The equipment and components in Room 110 were-uncontaminated, and the disposal of those items is discussed in Section 3.2.5.

\subsubsection{Removal and Disposal of Uncontam-} inated Equipment. Uncontaminated equipment in CFA-669, including equipment and components from Room 110, was removed and excessed for reuse or disposed of at the CFA landfill. The uncontaminated equipment was removed after the asbestos and radioactively contaminated equipment were taken from the building. The uncontaminated equipment in the main laundry building consisted of bathroom fixtures, some shelving, and a few electrical motors used in the HV system. The uncontaminated equipment and components in Room 110 consisted of the boiler, tanks, vessels, and ductwork from the boiler to the exhaust stack. The boiler and tanks were surveyed, released, and excessed for reuse or recycling.

Two options were evaluated for the removal of the 17-ton boiler from Room 110. One option was to size the boiler in place using a torch; the other was to hoist the boiler intact and place it on a flatbed trailer. Because of the significant cost savings, hoisting and excessing the boiler as a single unit were selected and performed. The process of hoisting the boiler from Room 110 and placing it on the flatbed trailer is shown in Figures 22 through 24.

When the boiler was jacked up and placed on cribbing for rigging, a localized spot of radioactive contamination was discovered on the floor beneath the south end of the boiler (Figure 25). The boiler, however, was uncontaminated, as determined by a complete survey of all external surfaces and accessible internal surfaces. The radiological survey results were documented with survey maps of the boiler. 


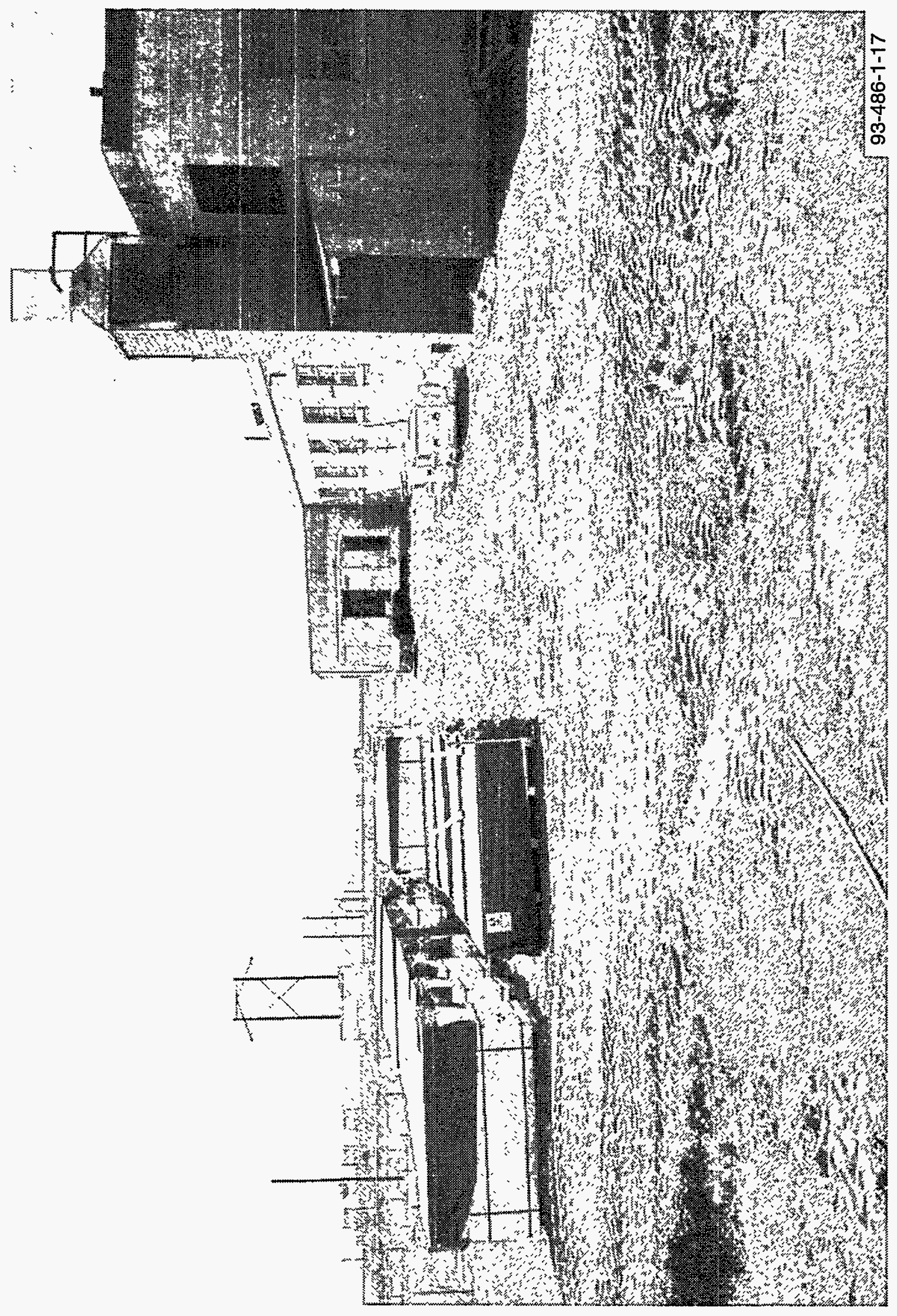

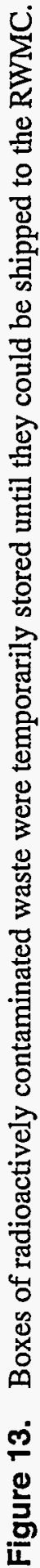




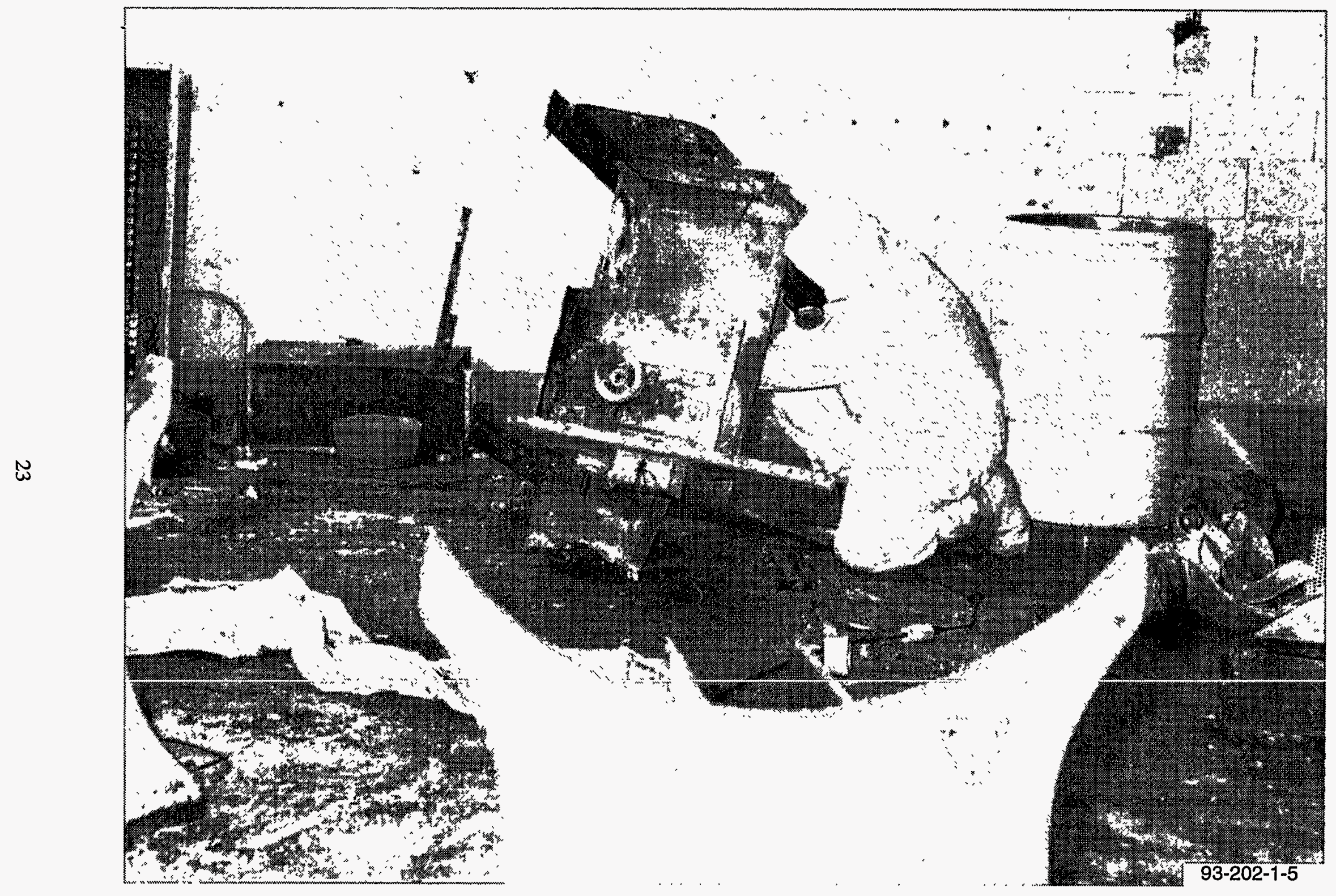

Figure 14. Disassembly/sizing of equipment in CFA-669. 


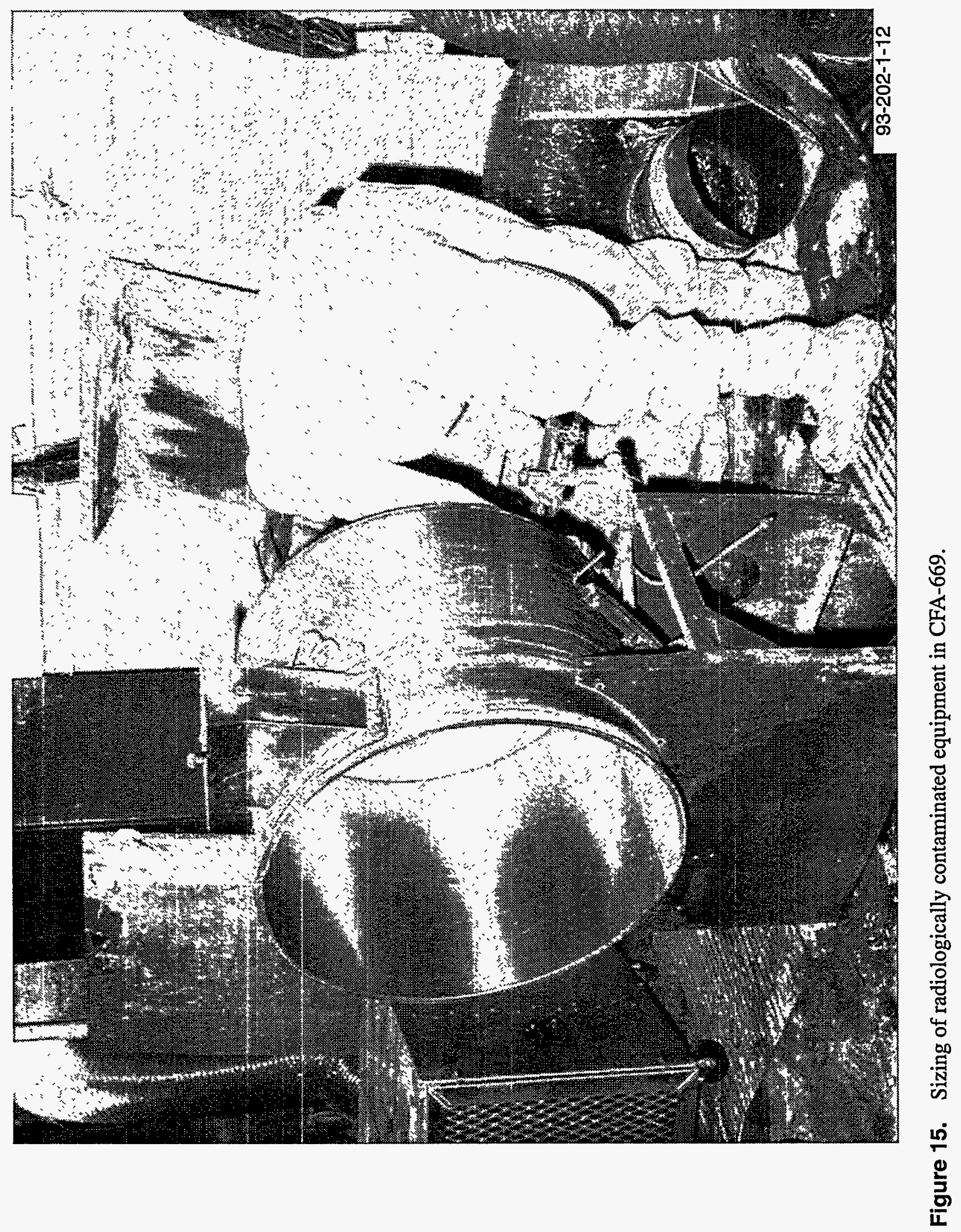




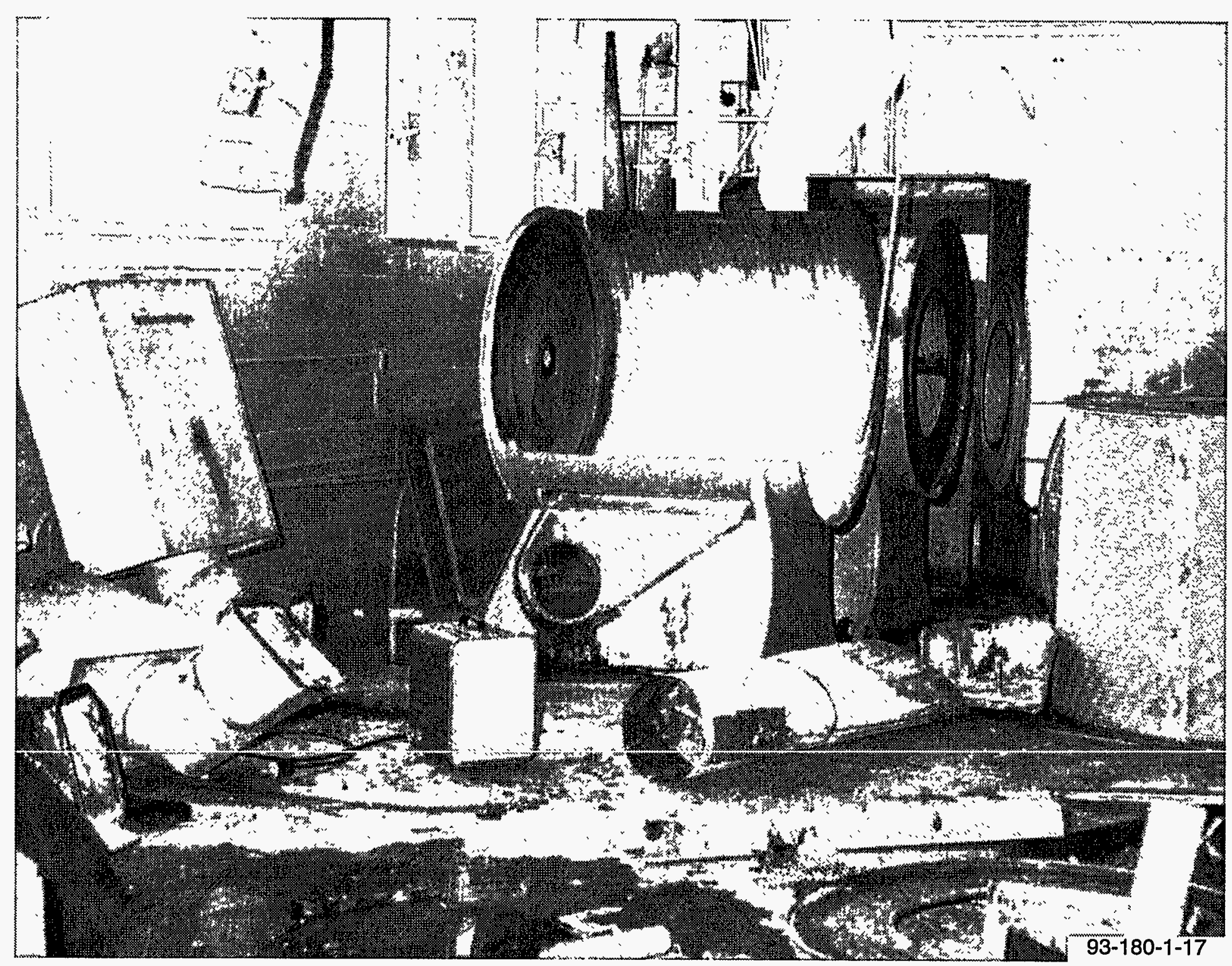

Figure 16. Disassembly of CFA-669 dryers. 


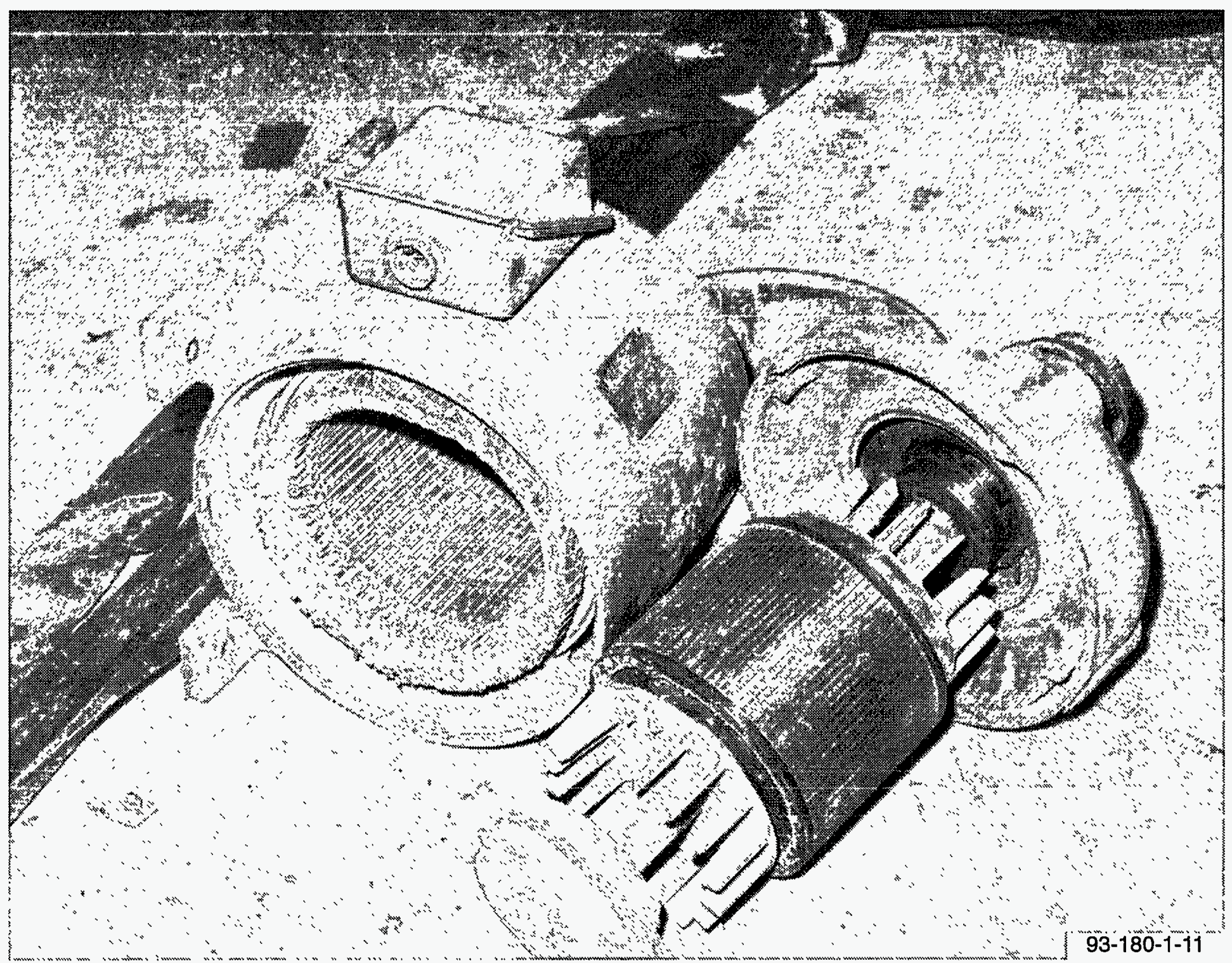

Figure 17. All electric motors were disassembled and inspected for hazardous waste before they were boxed for shipment to the RWMC. 


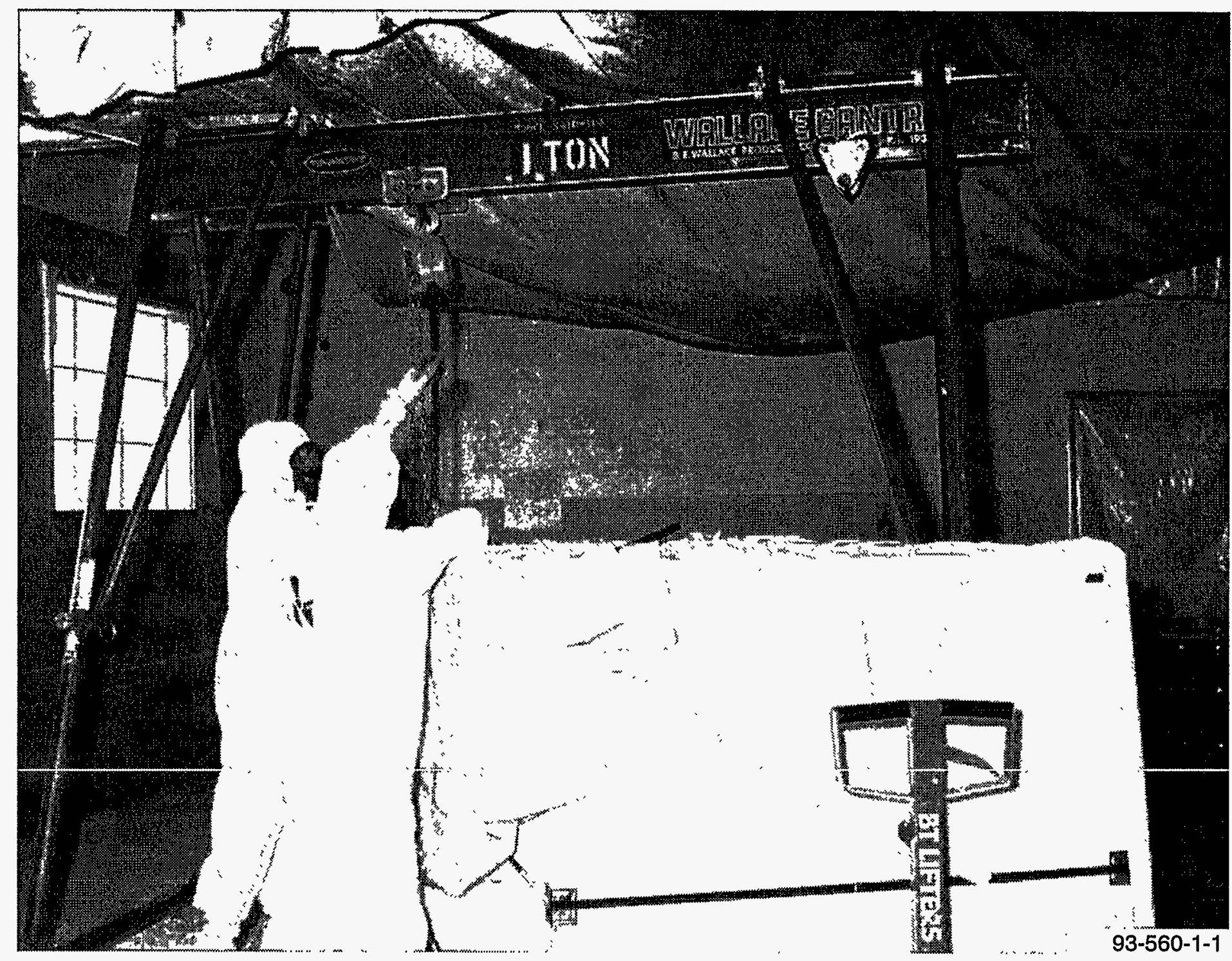

Figure 18. The Gantry crane was used to place heavy items into hot-waste boxes. A pallet dolly on each end of the box was used to move the box inside the building. 







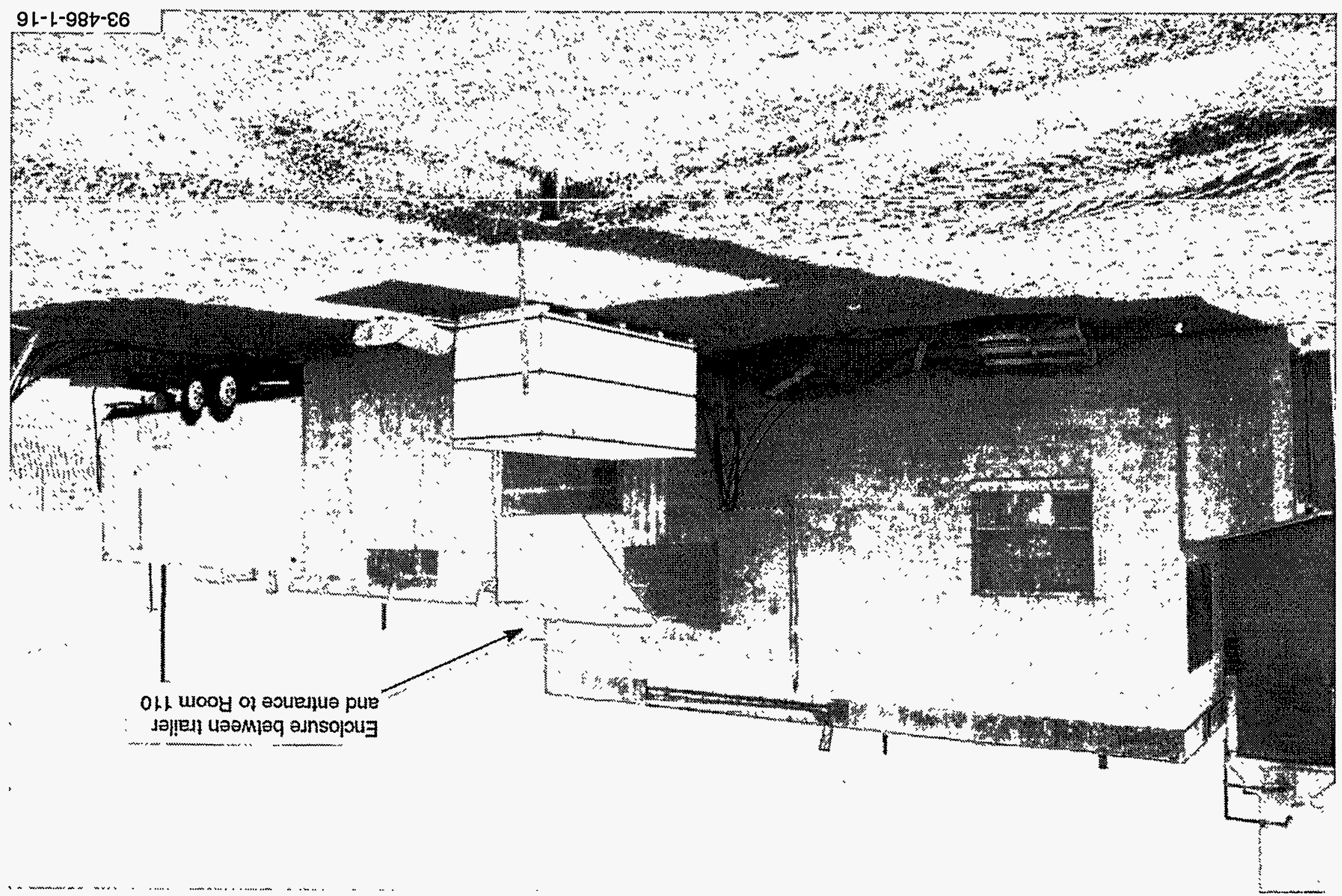




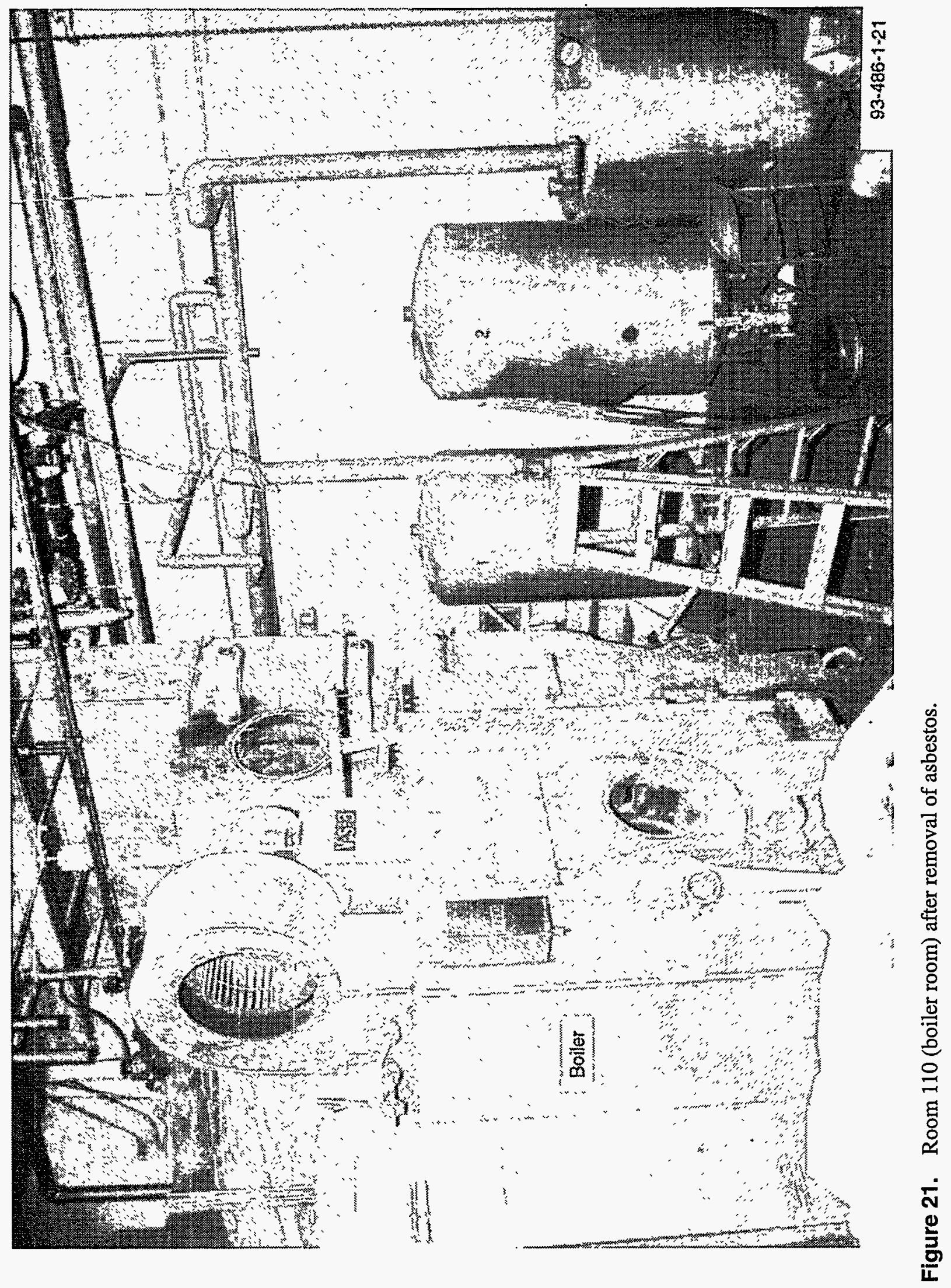




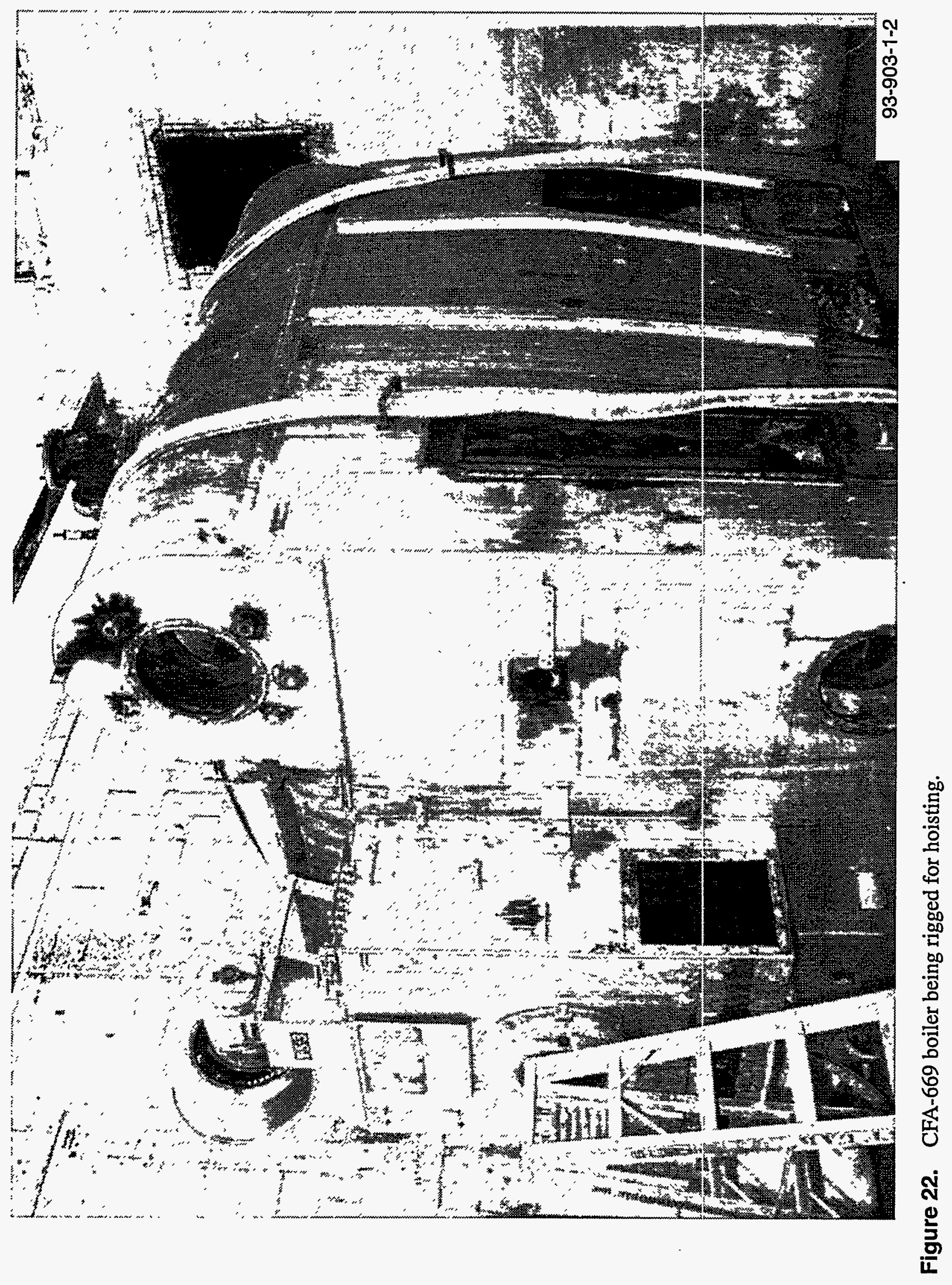




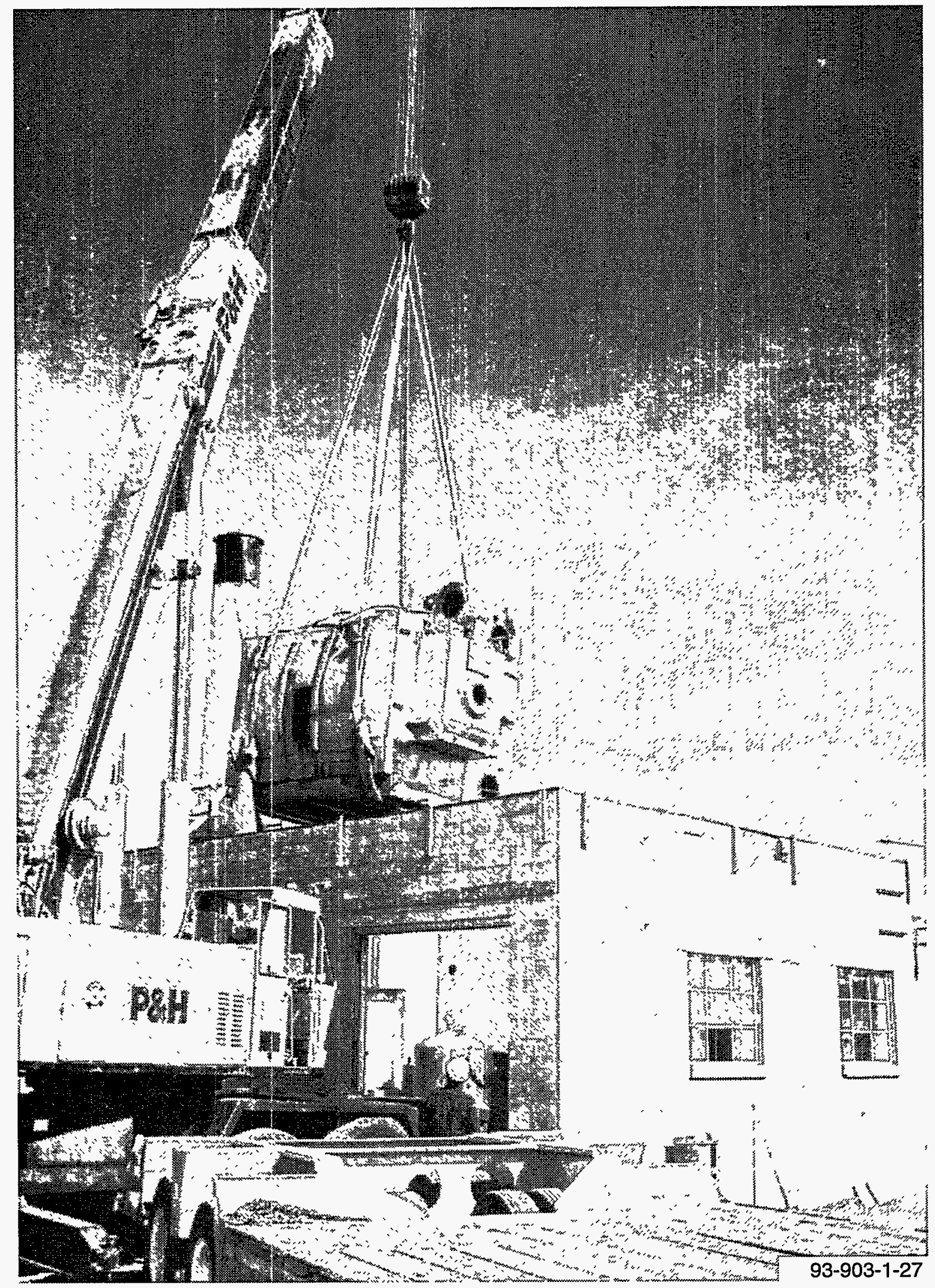

Figure 23. Hoisting of boiler. 


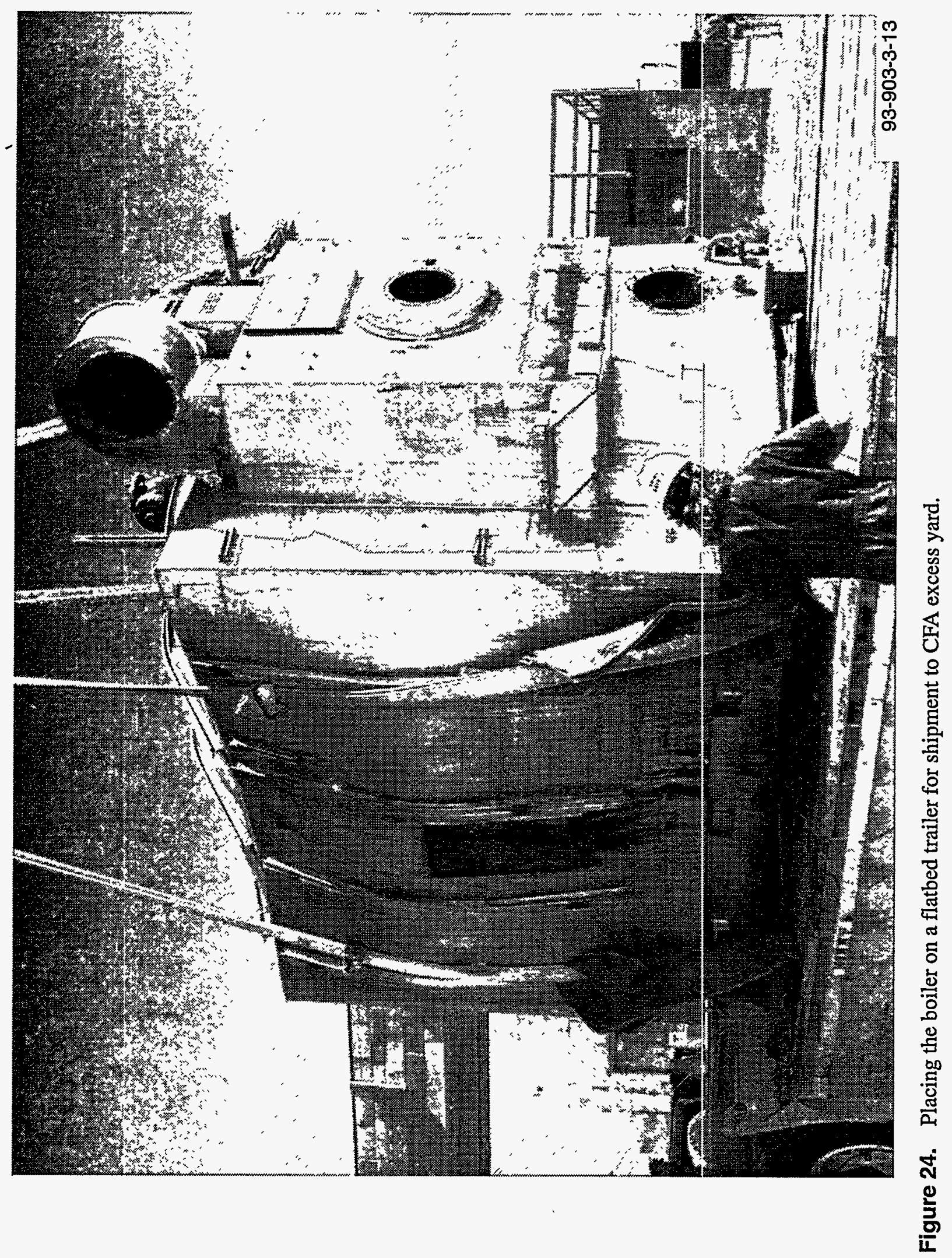




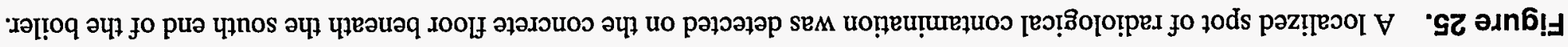

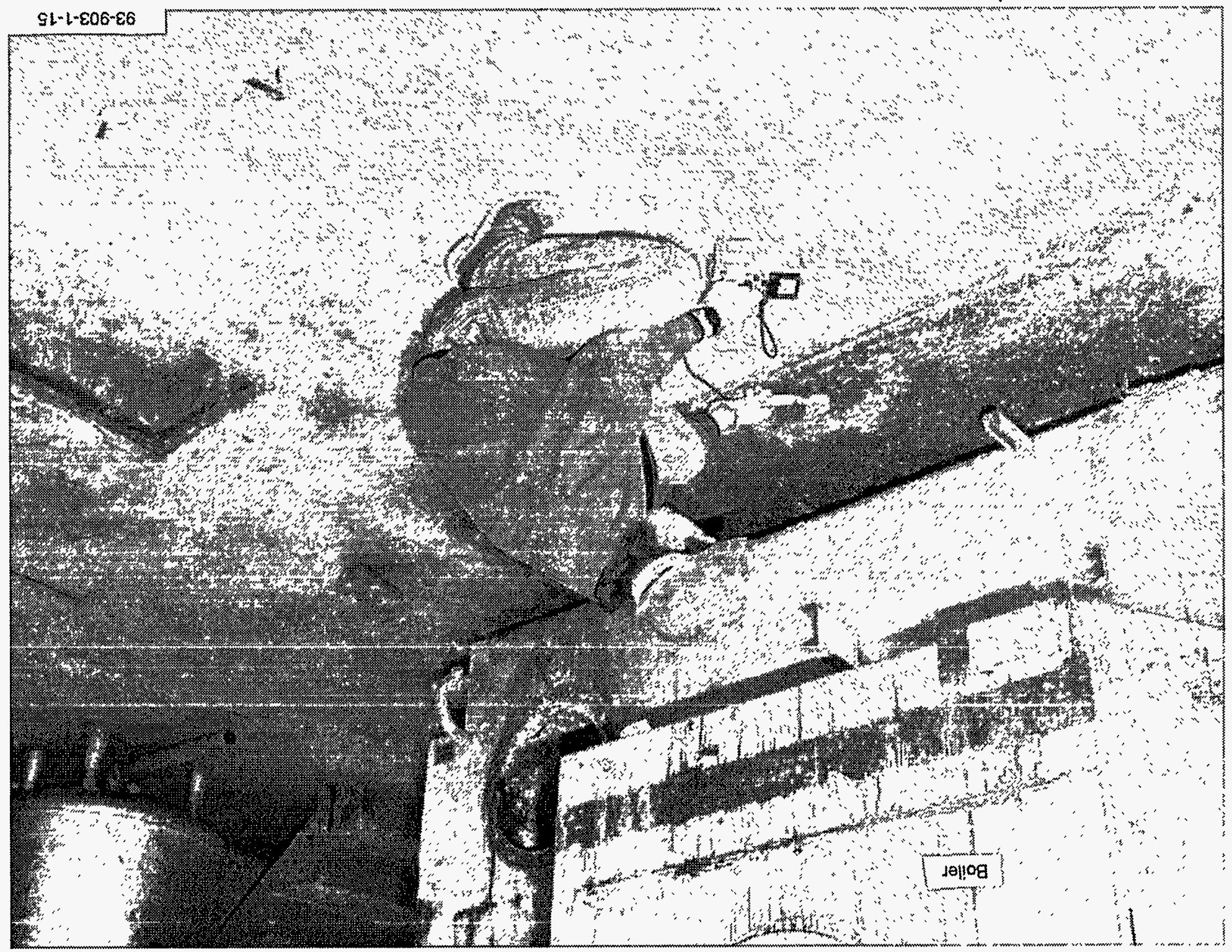


Before the boiler was released for reuse or recycling, internal samples were collected and analyzed for TCLP chromium. The analytical results were negative.

\subsubsection{Scabbled Contaminated Concrete.} The contaminated concrete floor and walls were scabbled after all the equipment and components were removed from inside the entire building. To minimize generation of dust during scabbling, the floor scabbler was equipped with a skirt and vacuum system. In addition, floor scabbling was performed inside an enclosure (Figure 26). Negative pressure was maintained inside the portable enclosure using an air mover equipped with HEPA filters. The concrete dust and chips generated during scabbling were bagged, boxed, and shipped to the RWMC for disposal.

The concrete drain trench in Room 108 was scabbled and chipped to depths of 4 in., but decontamination by scabbling was unsuccessful. The trench after scabbling is shown in Figure 27. Because of the depth of contaminant penetration in the trench, the decision was made to delay the removal/decontamination of the entire trench until the building was demolished. As an interim safety measure and to prevent contamination spread, the concrete drain trench in Room 108 was covered with steel plates and sealed with construction adhesive (Figure 28).

In order to reduce the radiation from the fixed contamination in the concrete floors, scabbling was performed first in Room 108, the room with the most contamination. Scabbling was then performed on contaminated areas in other rooms as indicated by surveys.

\subsubsection{Removal and Disposal of Contami- nated Filter Units on Roof. The contaminated filter units on the roof (see Figure 4) were discon- nected from the dryer exhaust ducting, lowered to the ground, and placed in special boxes for sizing at the WERF.}

Decontamination of the filter units was not attempted because of general internal contamination.
Sizing at the CFA-669 site was not attempted because of the cost savings in performing the sizing at WERF.

Five nonstandard boxes, $5 \times 5 \times 7 \mathrm{ft}$, were constructed in accordance with WERF specifications to contain and ship the filter units to WERF (Figure 29).

The removal of the filter units from the roof used the existing safety rail at the roof edge, thus allowing performance of this elevated work without constructing a new fall-protection system.

3.2.8 Decontamination of Loose Contamination. Loose contamination in the building interior was removed by vacuuming.

The vacuuming was accompanied by wire brushing to remove loose paint and scale. The vacuum fines were sampled and analyzed for TCLP metals. Analysis results were negative.

Following removal of loose contamination, the building interior was smeared, the smears counted, and the building verified free of loose contamination. A photo of the removal of loose contamination is shown in Figure 30.

This decontamination effort eliminated the potential for airborne contamination and allowed subsequent gridding and survey of the building interior without using personal protective equipment (PPE).

\subsubsection{Gridding and Survey of Building} Interior. The building interior, except for Room 110, was gridded and surveyed in accordance with the Radiological Survey Plan for the CFA-669 Hot Laundry (Reference 6). Room 110 was not included in the survey effort because no radiological contamination had been detected within its confines.

The walls, floors, and ceilings were gridded into $1-\mathrm{m} \times 1-\mathrm{m}$ grid squares and numbered according to the numbering system specified in Reference 6. 


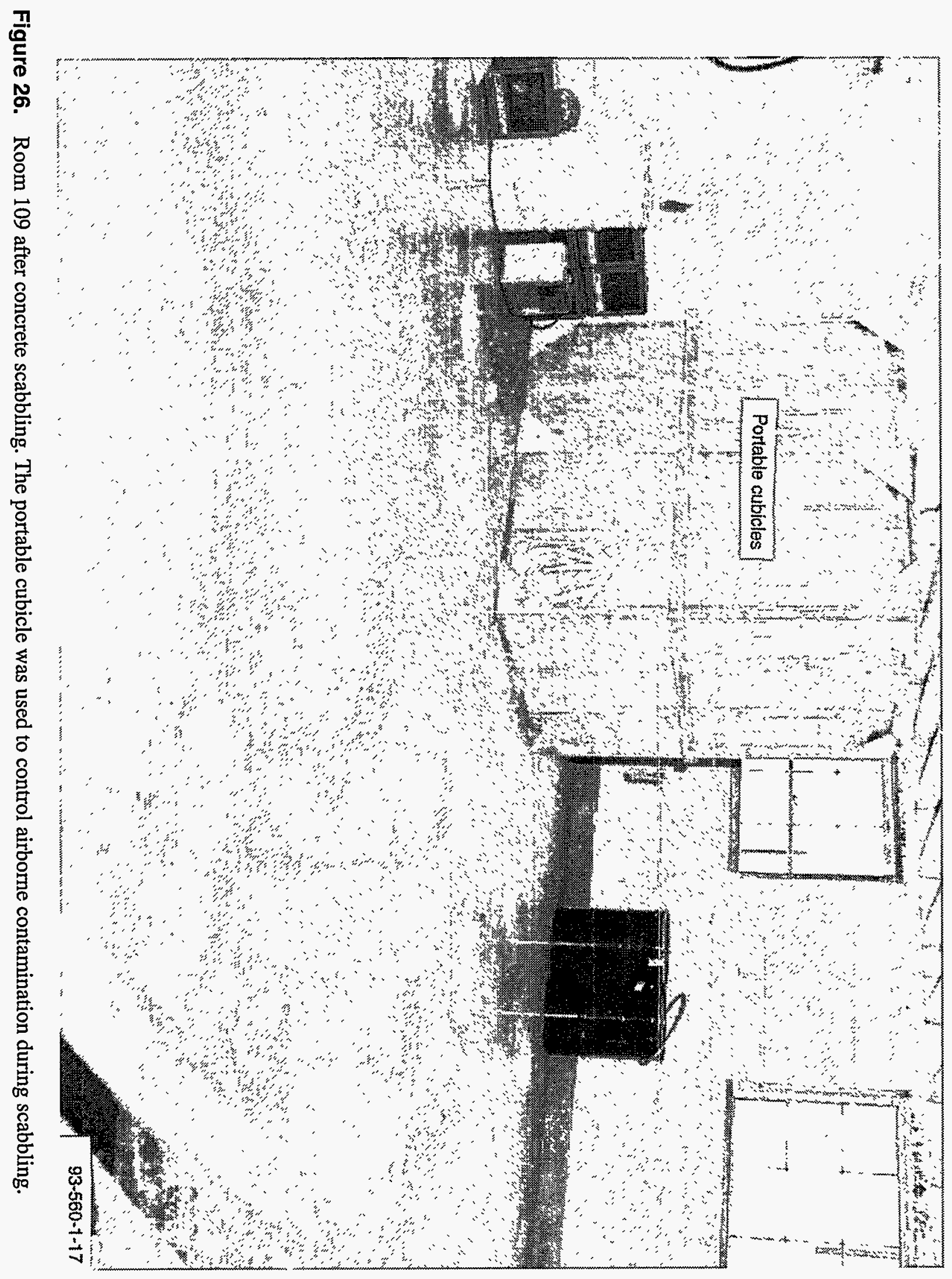




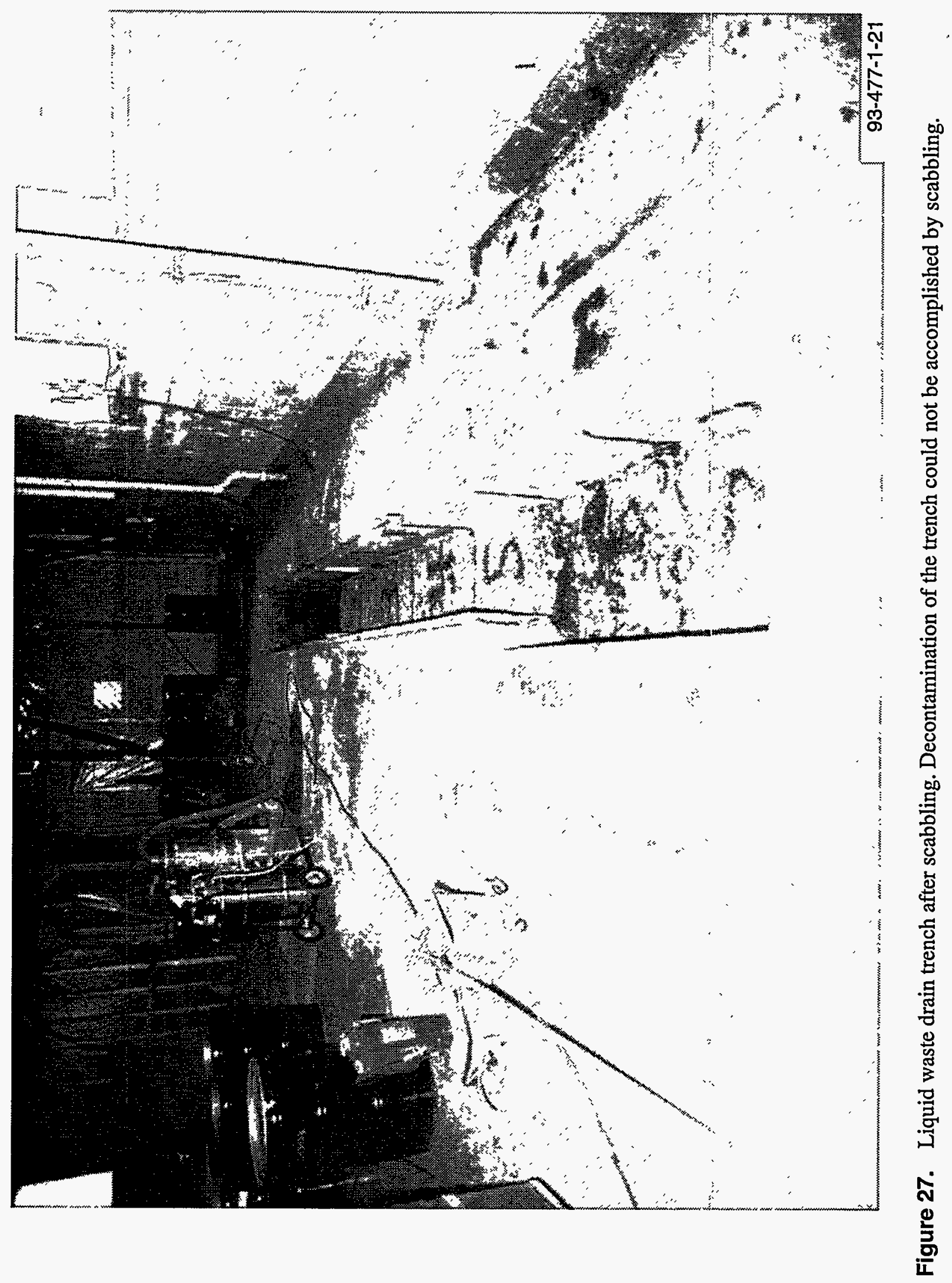




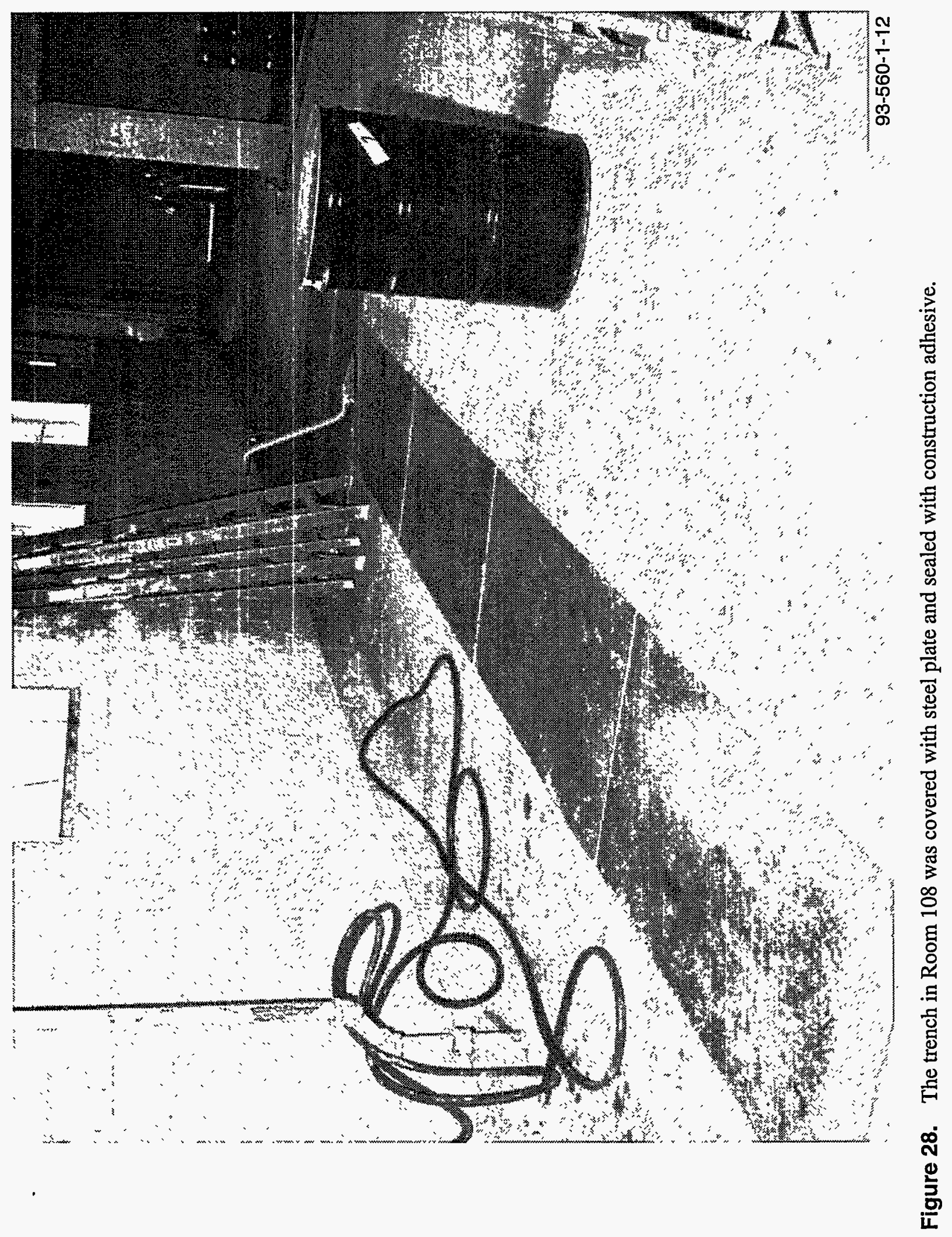




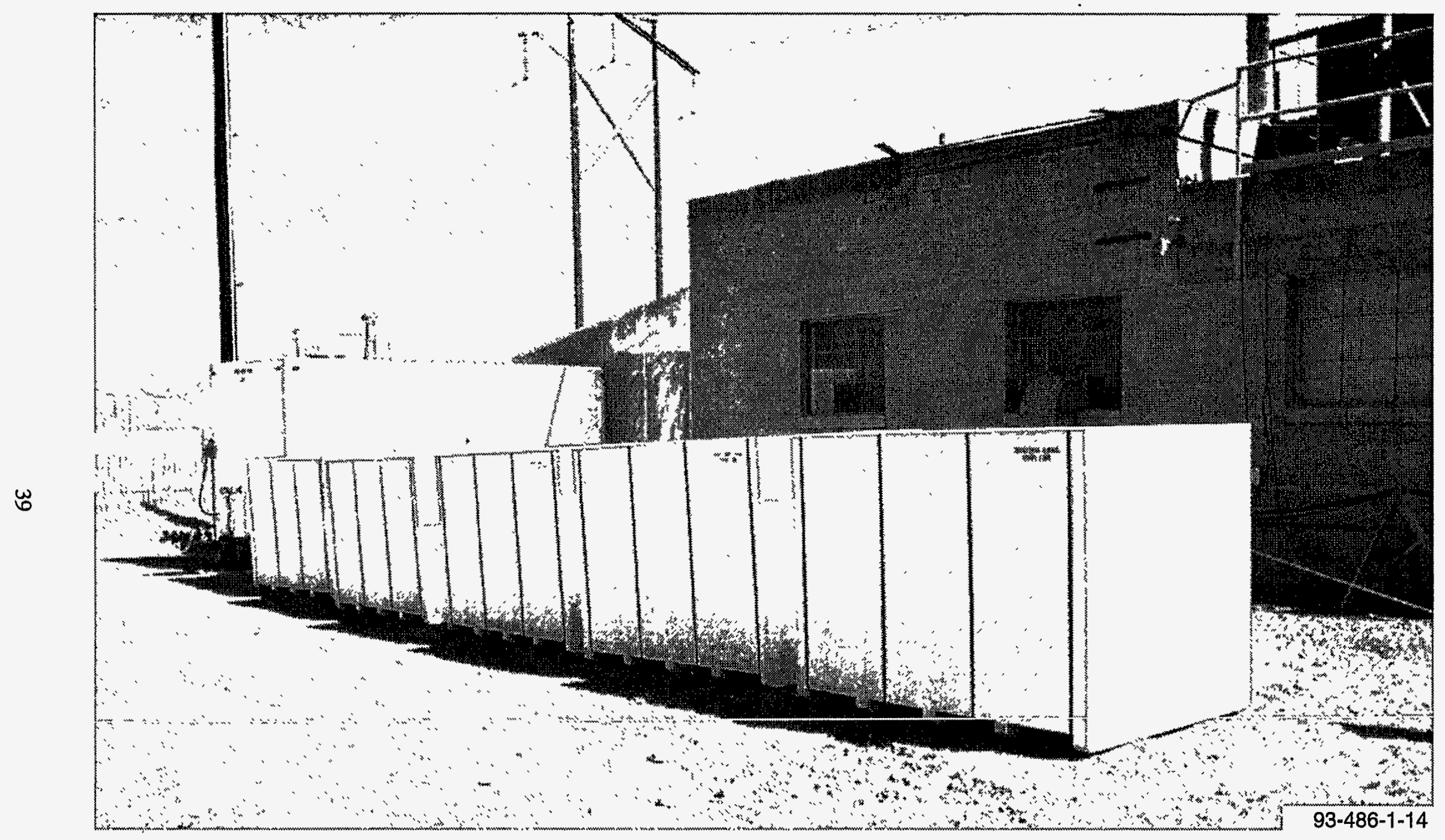

Figure 29. Five special boxes were built and used to contain contaminated filter units from the roof of CFA-669. 


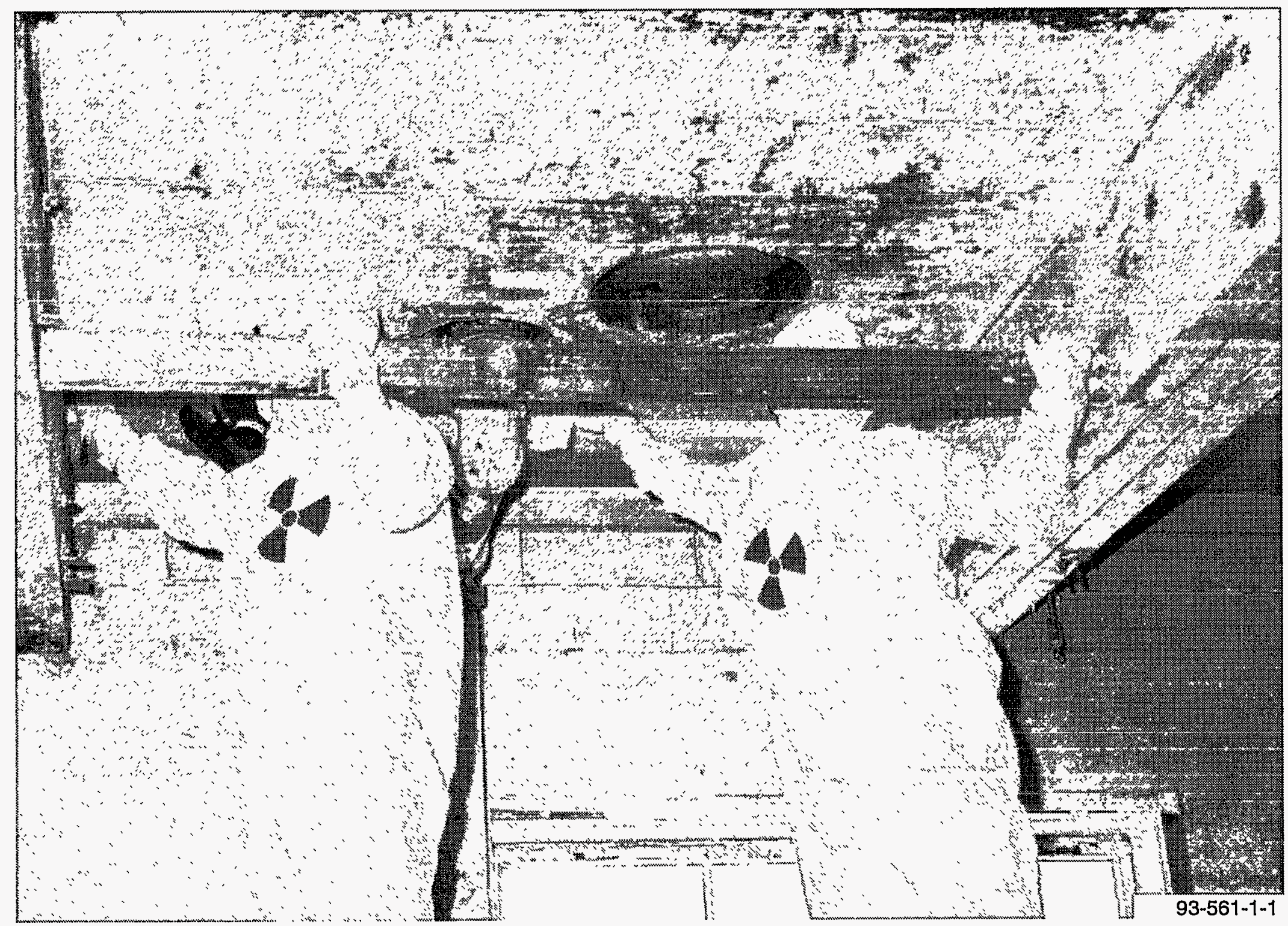

Figure 30. Loose contamination was removed from the interior of CFA:669 by brushing and vacuuming. 
The fixed radiological contamination survey, as specified in Reference 6, included beta/gamma and alpha. The survey was performed grid by grid using hand-held instruments (Figure 31).

The purpose of gridding and surveying was to identify low-level fixed contamination not detected during the scabbling activity described in Section 3.2.6.

During the survey, any detected fixed contamination was appropriately marked for subsequent removal.

\subsubsection{Removal and Disposal of Roofing} Material. The roof of CFA- 669 consisted of concrete panels covered by Celetex, several layers of asbestos-containing tar paper, and gravel roofing material.

The roofing material on the concrete roof panels was removed and disposed of as either radioactive asbestos waste at the RWMC or uncontaminated asbestos waste at the CFA landfill. Radioactively contaminated roofing material was identified by radiological surveys of the roof.

Before the roofing material was removed, a fall-protection rail was constructed around the roof perimeter (Figure 32).

Figures 33 and 34 show the removal and boxing of contaminated roofing material.

\subsubsection{Decontamination of Fixed Contami-} nation in Building Interior. This decontamination effort removed fixed contamination in the building (identified during the survey described in Section 3.2.9). In addition, any loose contamination resulting from removal of roofing material and from seams between the concrete panels was removed.

Decontamination was performed by first vacuuming any loose material, then by additional scabbling and chipping of the grid squares identified during the radiological survey.
Using field instruments during decontamination, workers verified that each area previously identified as contaminated was uncontaminated before work moved to another designated contamination area.

Inaccessible, fixed-contamination areas, such as the interior of some concrete blocks and the concrete trench in Room 108, were not decontaminated during this effort. Removal of inaccessible contamination was delayed and is discussed later.

\subsubsection{Removal and Disposal of Concrete} Roof Panels. The concrete roof panels were lowered to the ground, radiologically surveyed, and disposed of in the CFA landfill. A few concrete panels required decontamination of localized spots of radiological contamination. Figures 35 through 38 show removal, survey, and disposal of the concrete roof panels.

\subsubsection{Re-Gridding and Re-Surveying Building Interior. The building interior was} re-gridded and re-surveyed to assess the effectiveness of the previous decontamination effort to remove fixed, accessible contamination. Only a few localized spots of contamination were detected. These spots were identified for subsequent removal. Existing grid lines were used where visible. Where not, new grid lines were established. Figure 39 shows the detector used to survey the floors. This detector is a special instrument containing an Eberline Model RM-14S for the electronics and a Ludlum Model 43.37 detector. The instrument identified areas containing alpha, beta, or gamma contamination above background. Following decontamination of identified areas, each area was verified releasable using a calibrated hand-held instrument.

\subsubsection{Decontamination of Remaining} Fixed, Accessible Contaminations. Localized spots of remaining fixed contamination identified during the last iteration of surveying were removed by chipping the surface and vacuuming the loose particles. This final decontamination effort rendered the building interior free of contamination except for those areas where contamination was inaccessible. 


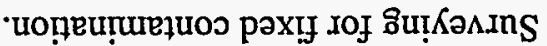

• เ

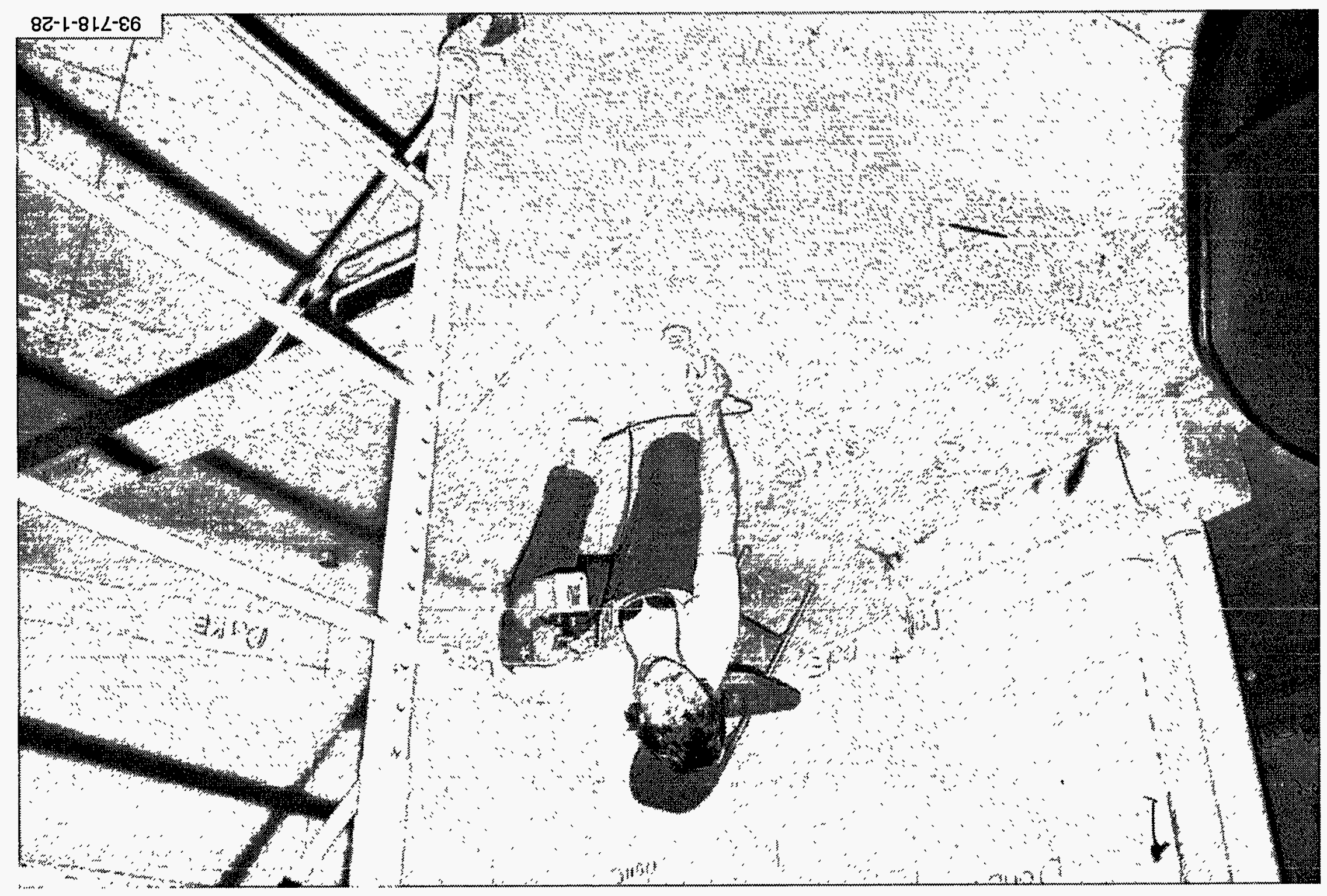




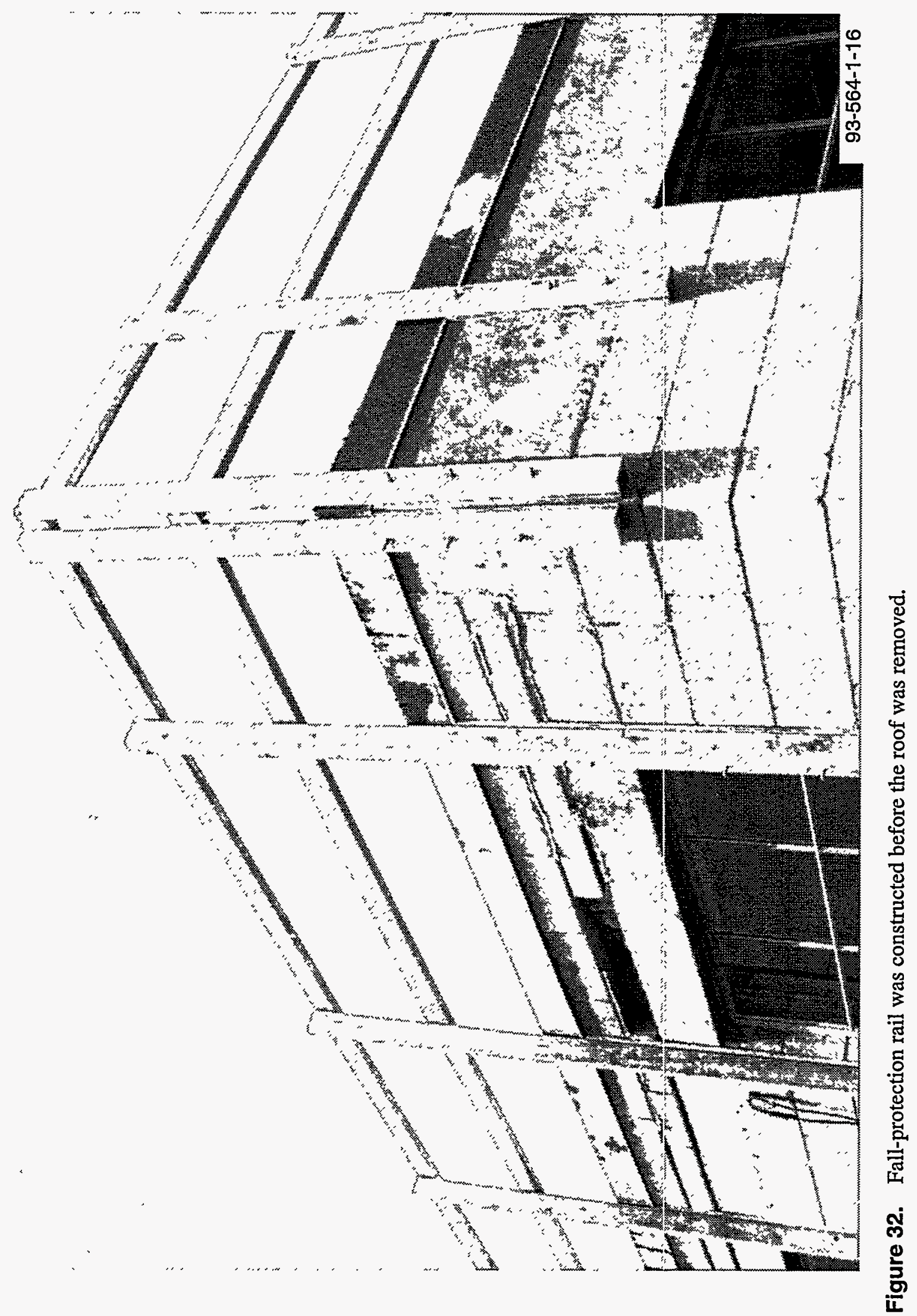




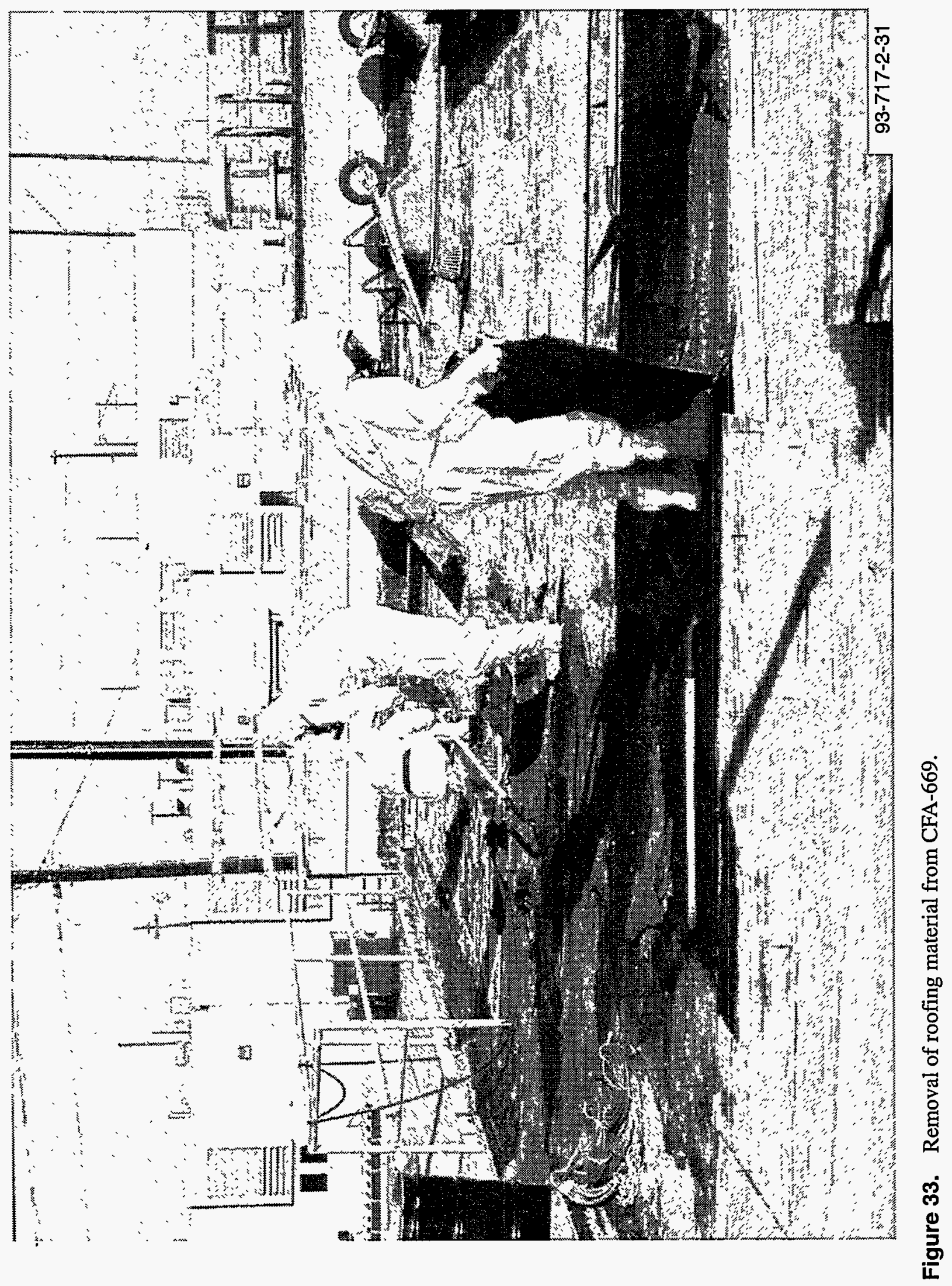




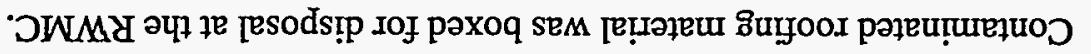

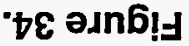

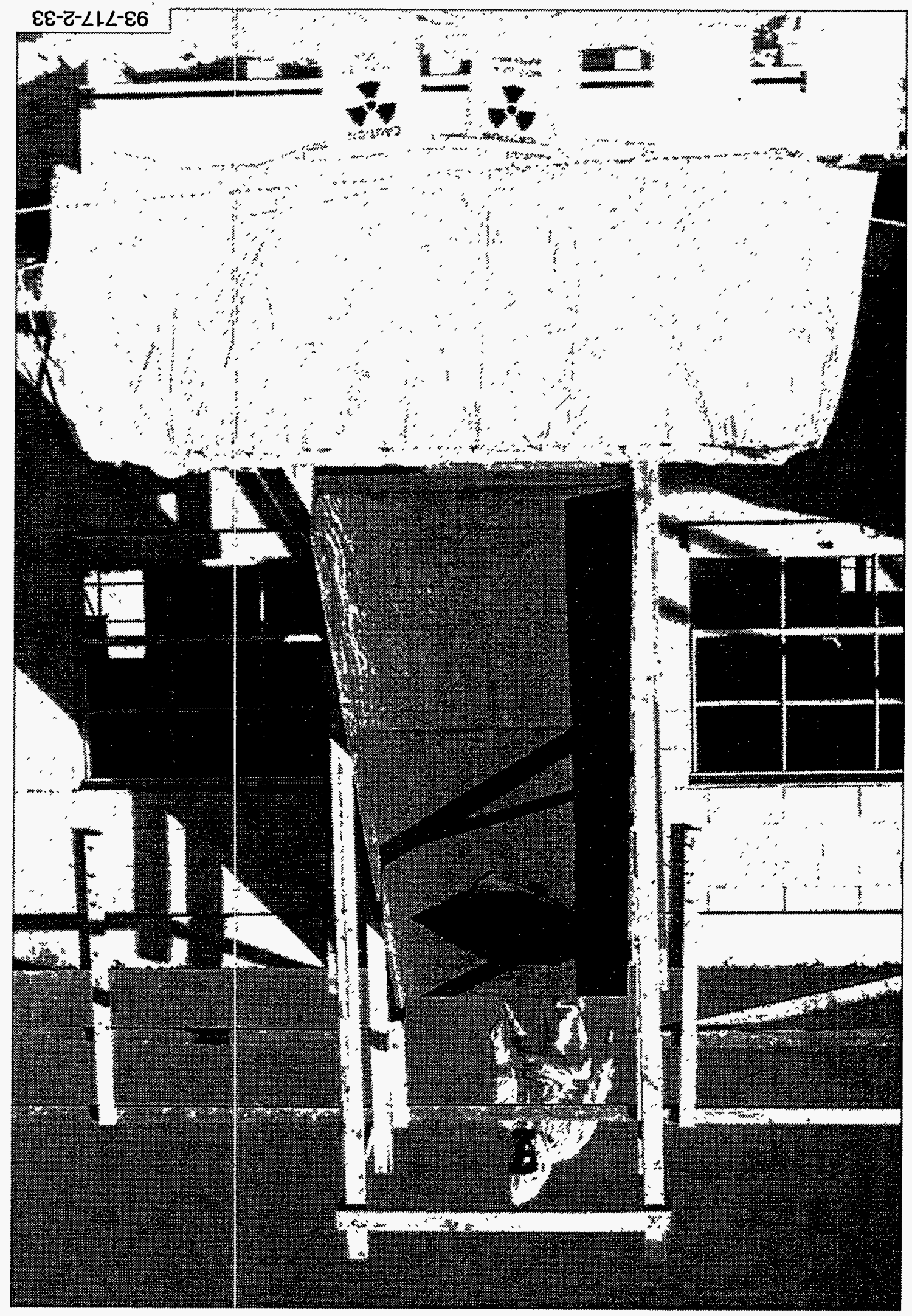




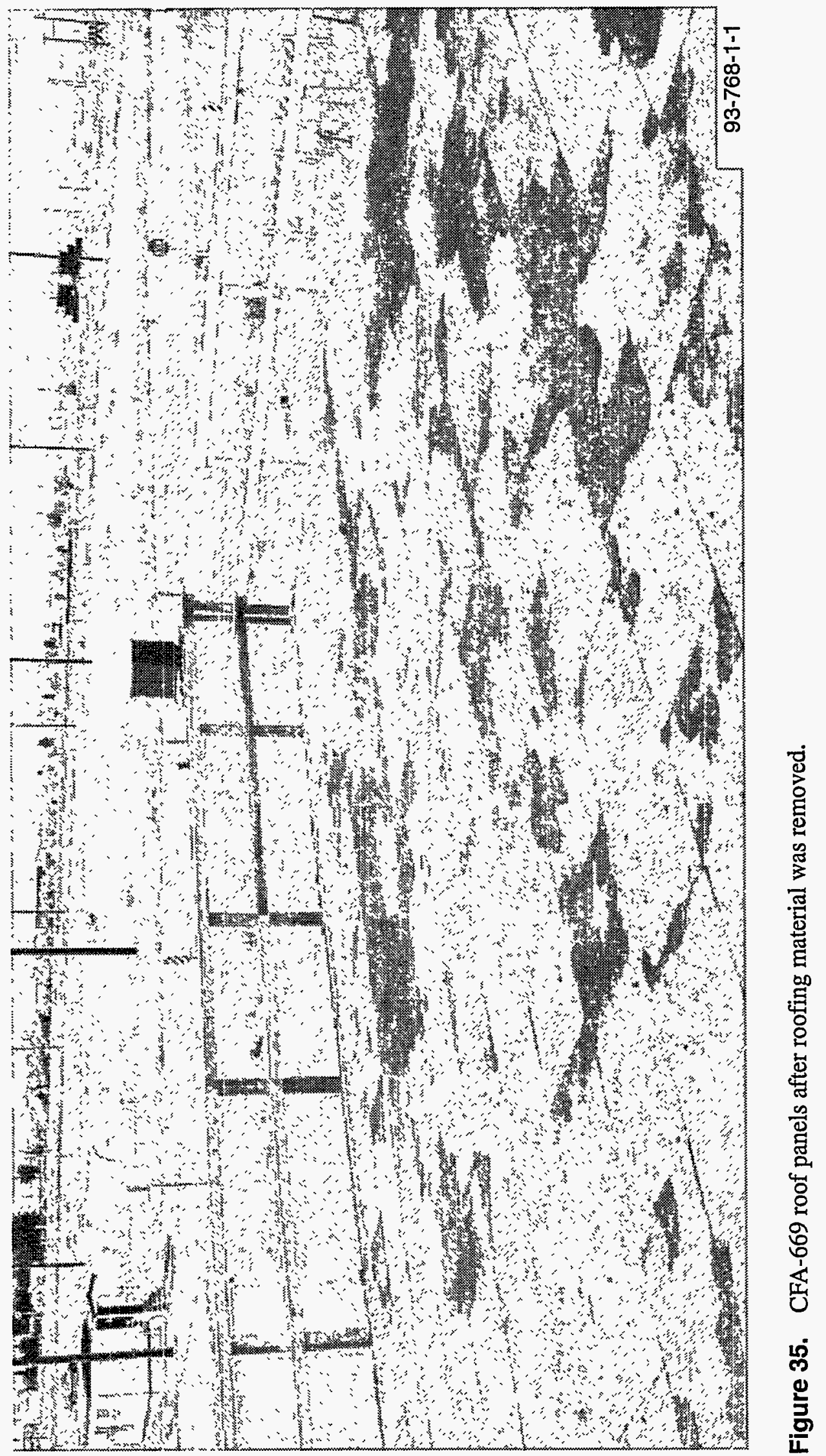




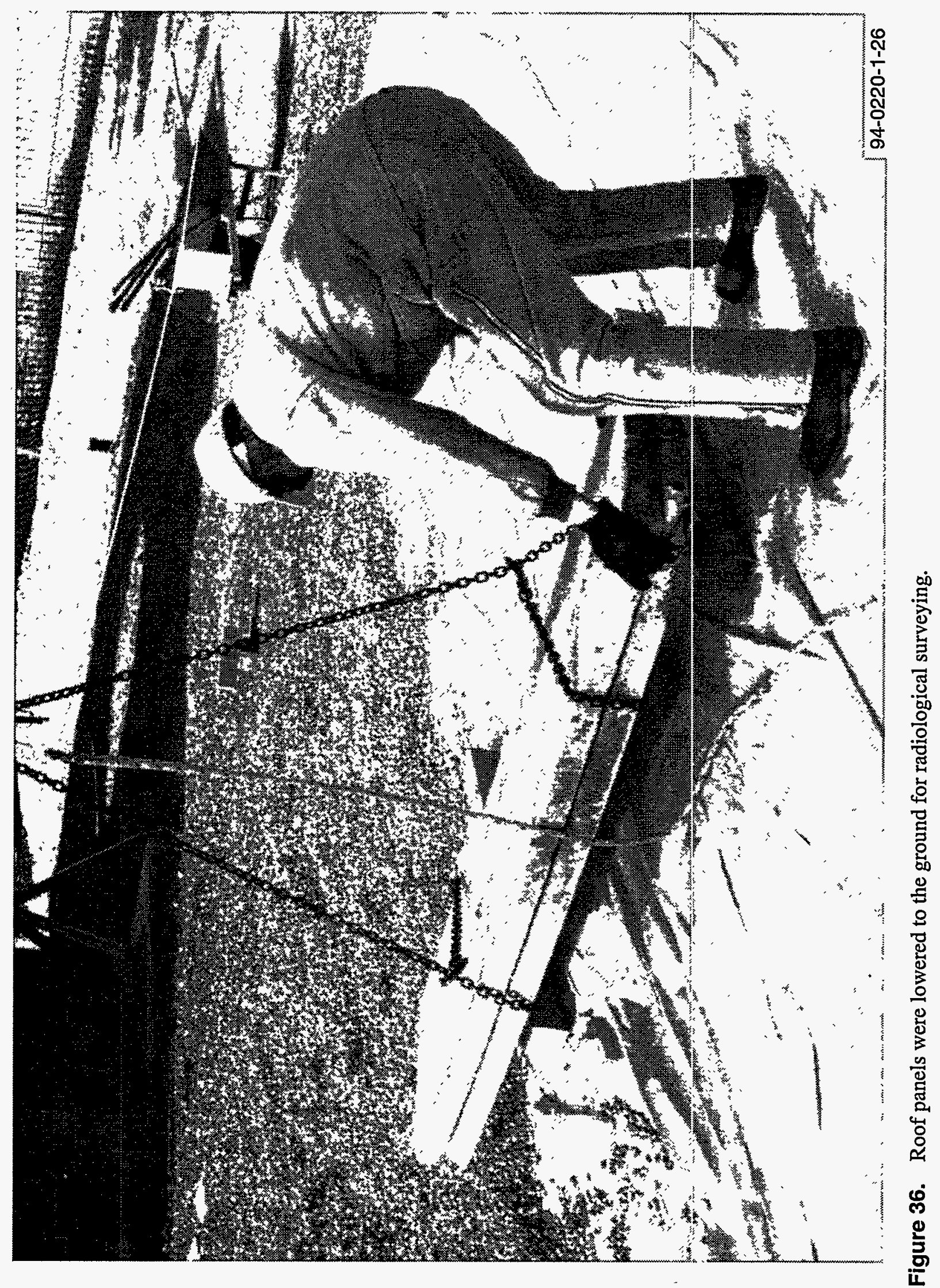




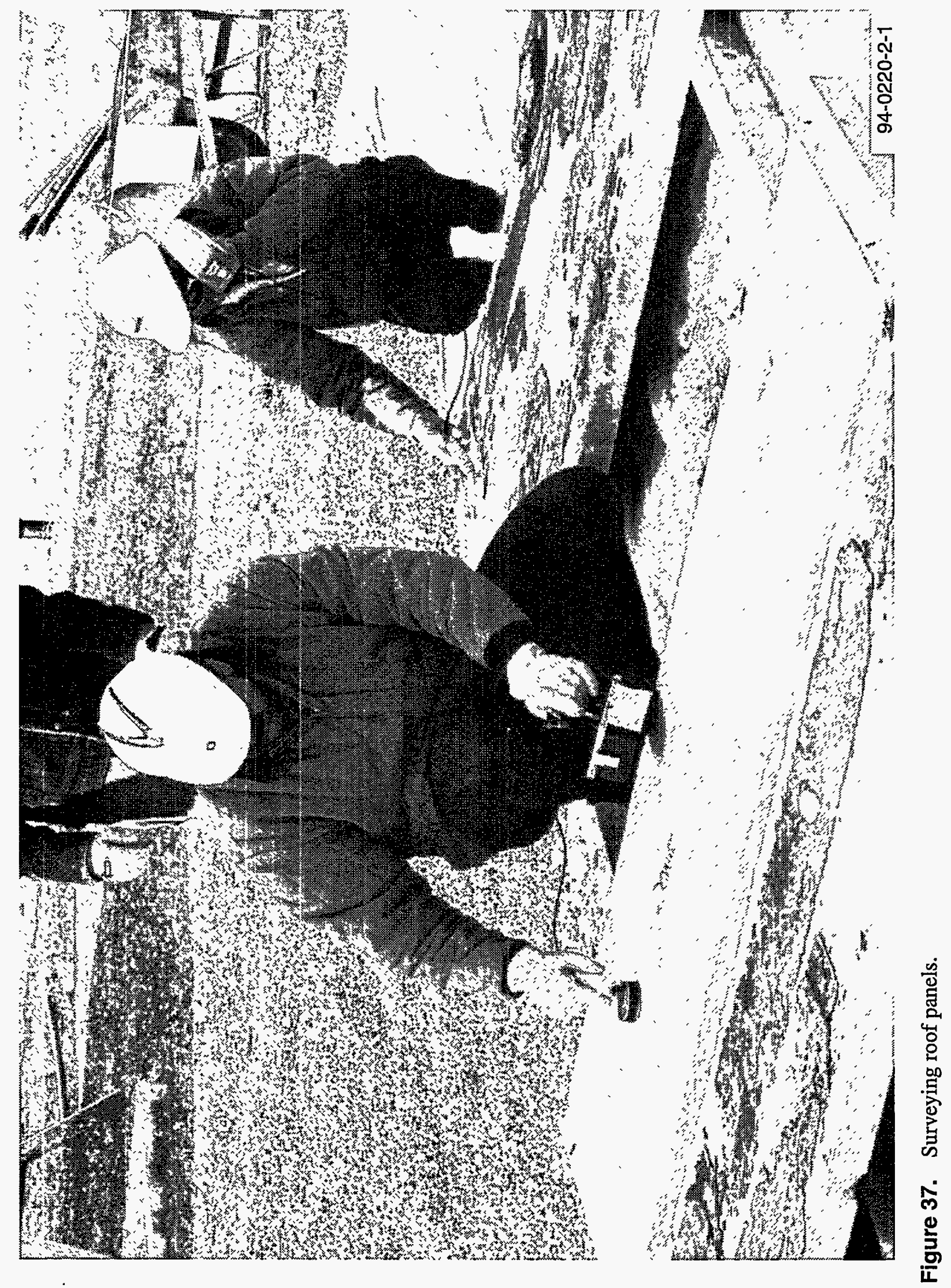




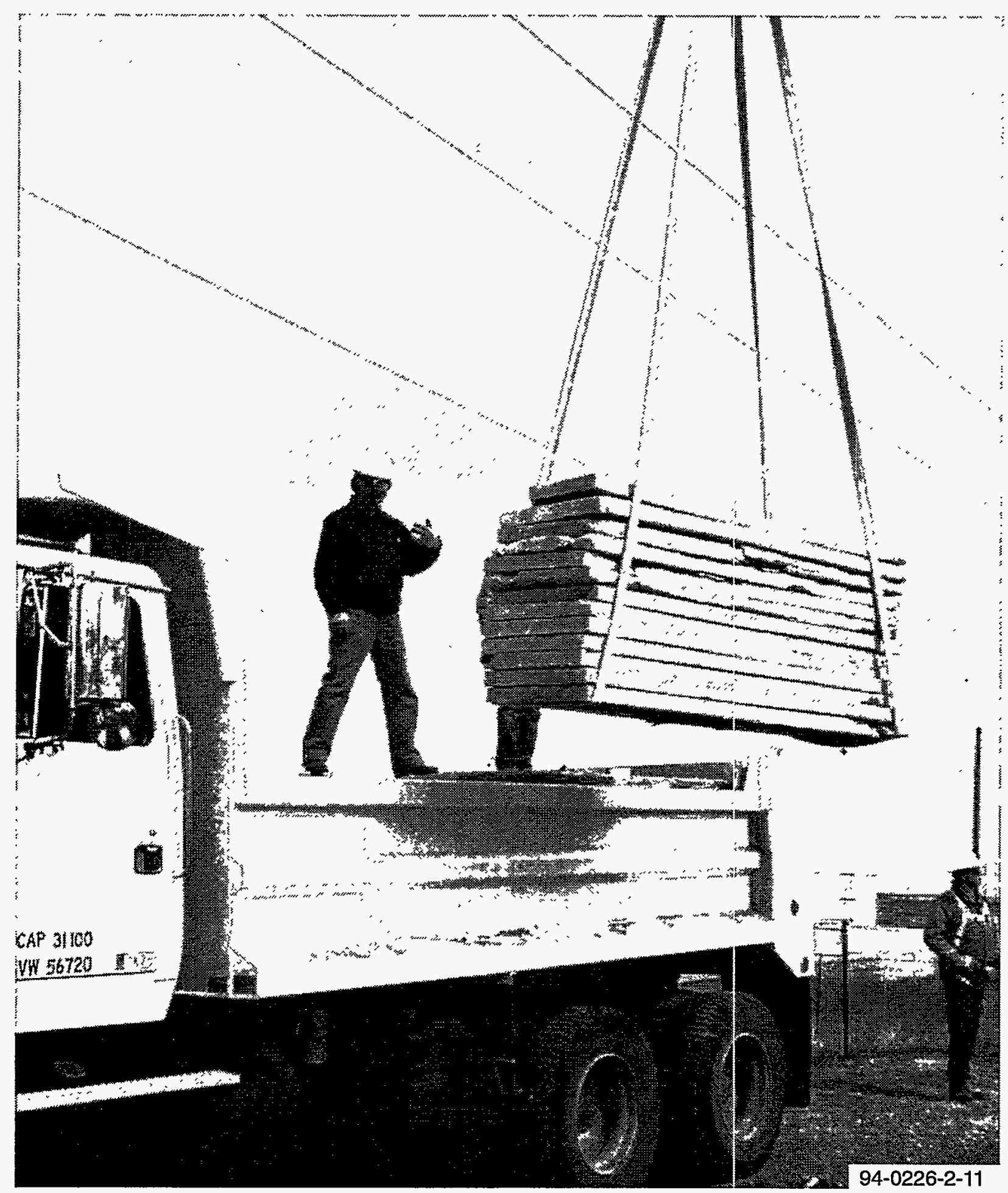

Figure 38. Roof panels were loaded onto a truck to be transported to the CFA landfill for disposal. 


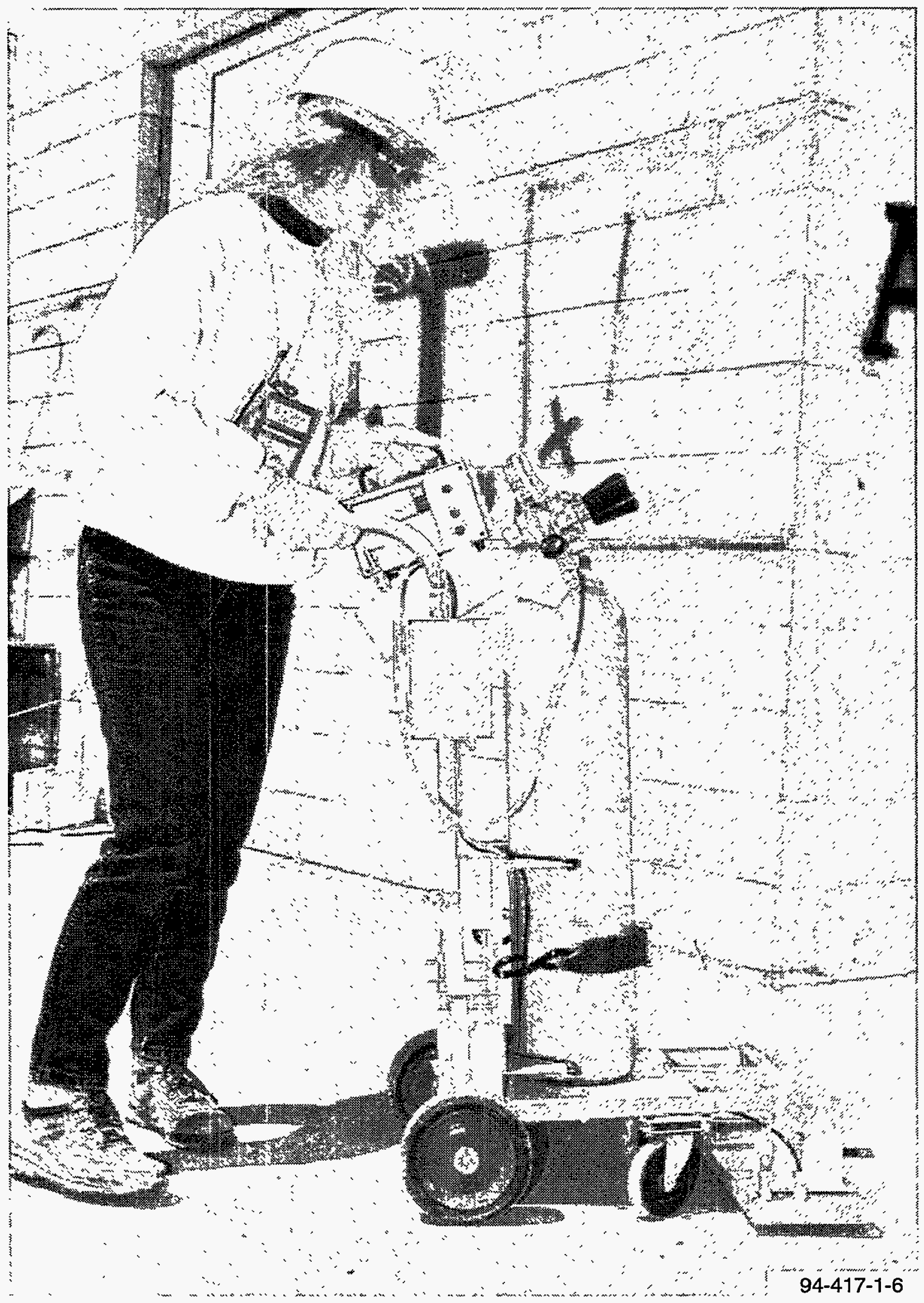

Figure 39. Instrument used to perform the final survey of the floor of CFA-669. 
3.2.15 Survey of Building Exterior. Following removal of all fixed accessible contamination inside CFA-669, the exterior surfaces of the walls were gridded and surveyed to verify releasability before the building walls were demolished.

\subsubsection{Removal and Disposal of Inacces-} sible Contamination. There were several areas with fixed, inaccessible contamination. These areas included:

- Inside the concrete blocks located at the top of interior walls and the north wall of Room 108.

- The interface surface where concrete block walls sat on the concrete slab floor in some locations.

- The concrete trench in Room 108 that had previously been unsuccessfully scabbled then covered with steel plates.

The inaccessible contamination in the concrete blocks was removed by carefully dismantling the walls (Figure 40), surveying each suspected block, and segregating the contaminated from the uncontaminated concrete blocks. Except for the bottom row of concrete blocks, the outside walls were demolished using a concrete processor (Figure 41 ). The bottom row was disassembled by hand (Figure 42), and each concrete block was surveyed for radioactivity.

The contaminated concrete trench was removed by sawing the concrete, then jackhammering the concrete within the saw cut. Next, the contaminated soil was removed as shown in Figure 43.

\subsubsection{Dismantlement and Disposal of} Building. The building was dismantled, then disposed of at the CFA landfill (except for the wooden roof beams, which were excessed for reuse). Figure 44 shows the wooden beams being lowered to the ground for final survey before they were excessed for reuse. The building walls were dismantled after the exterior had been surveyed and released. Except for the bottom row of concrete blocks, the walls were dismantled using a tractor-mounted concrete processor (Figure 41). The bottom row was dismantled by hand, and each concrete block was surveyed for radioactivity (Figure 42 ).

\subsubsection{Removal and Disposal of Concrete} Slab and Footings. The concrete slab was verified releasable, then jackhammered using a tractor-mounted jackhammer, loaded into dump trucks, and disposed of in the CFA landfill. Next, the footings were excavated with a trackhoe and removed using the tractor-mounted concrete shear (Figure 45).

\subsubsection{Excavation and Disposal of Uncon-} taminated Piping. Uncontaminated piping consisted of one 8-in. concrete sanitary sewer line, one 4-in. iron water pipe, and a 2-in. steel steam line. The sanitary sewer line was removed to the manhole located approximately $75 \mathrm{ft}$ southeast of CFA-669. The water line was removed from CFA-669 to the shutoff valve located approximately $50 \mathrm{ft}$ northwest of CFA-669. A photo of the blind flange, valve, and main water line is shown in Figure 46 prior to backfilling the flange, valve, and main water line. The steam line was removed to a point approximately $50 \mathrm{ft}$ north of CFA-669, where the pipe had been cut and plugged during activities described in Section 3.2.1. All the removed, uncontaminated piping was disposed of in the CFA landfill.

\subsubsection{Excavation and Disposal of Con- taminated Pipe and Associated Soil. The} 8 -in. contaminated concrete pipe was removed in sections, bagged, and placed in waste boxes for disposal at the RWMC.

The contaminated soil beneath and adjacent to the pipe was removed, boxed, and disposed of at the RWMC.

Figure 47 shows the 8 -in. contaminated concrete pipe after excavation. The contaminated soil beneath and adjacent to the pipe was removed by vacuuming and hand shoveling, as shown in Figure 48. 


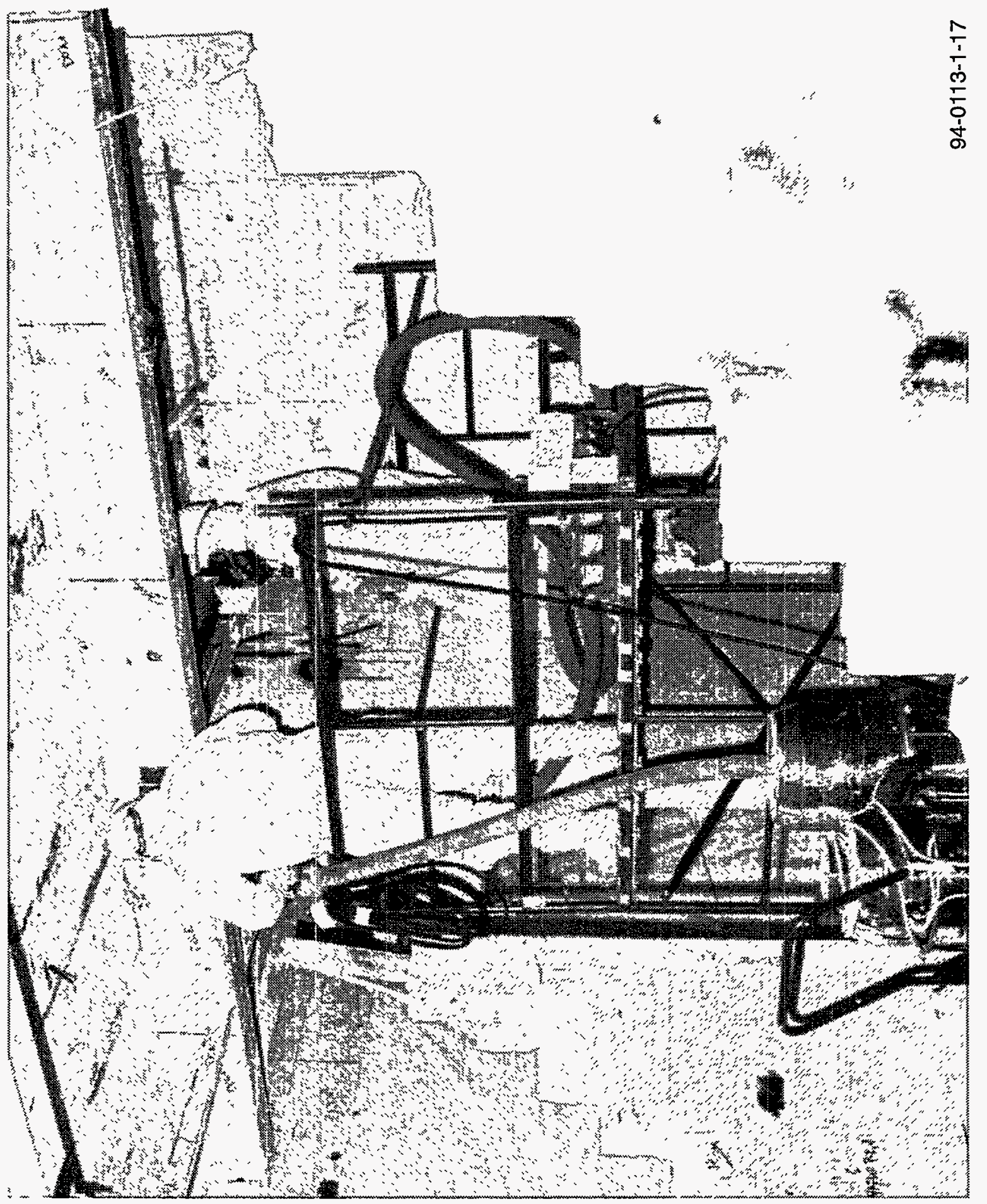

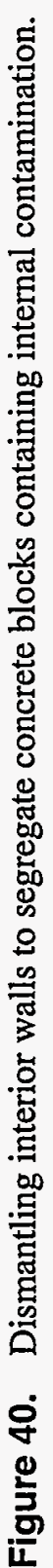




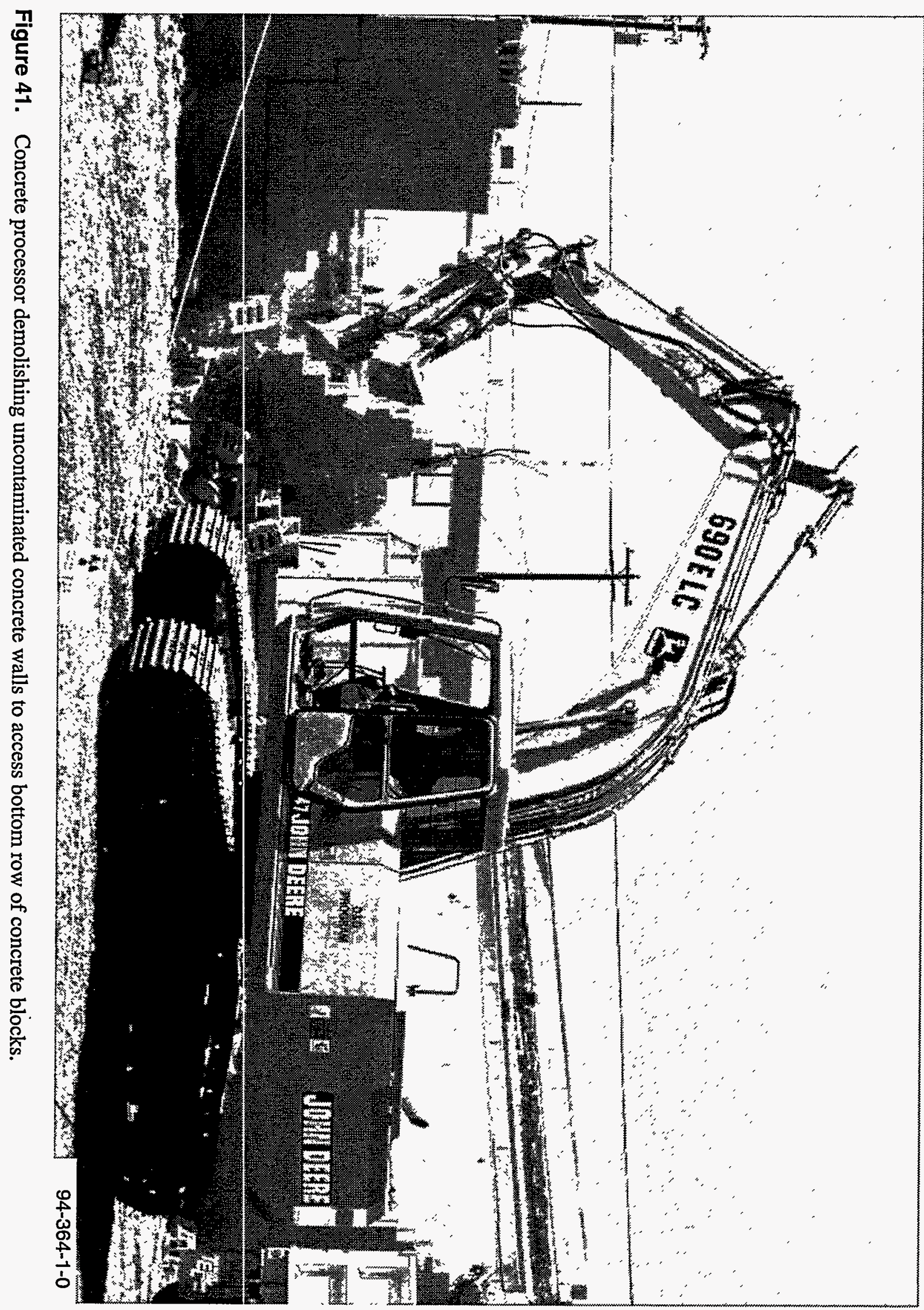




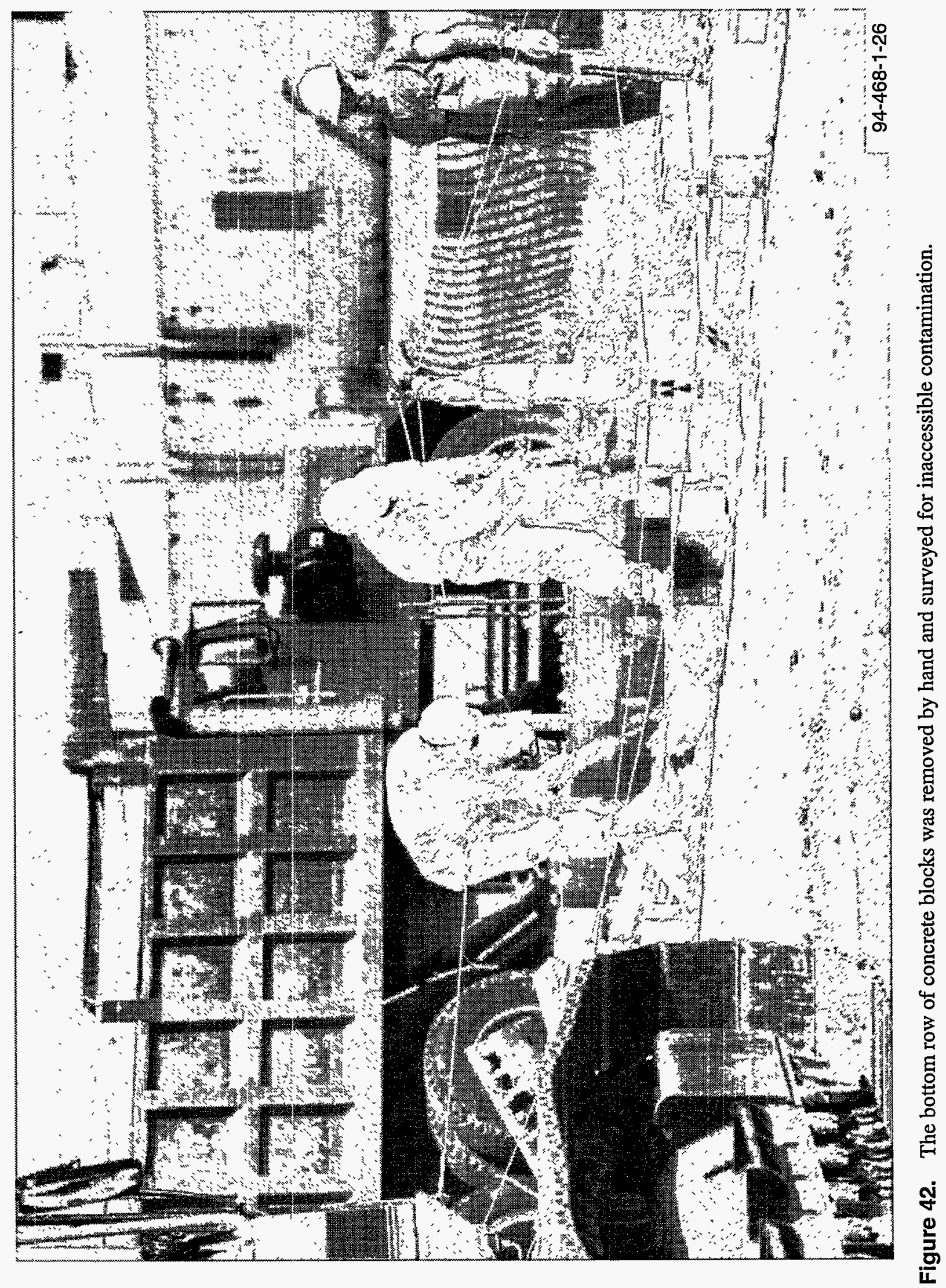




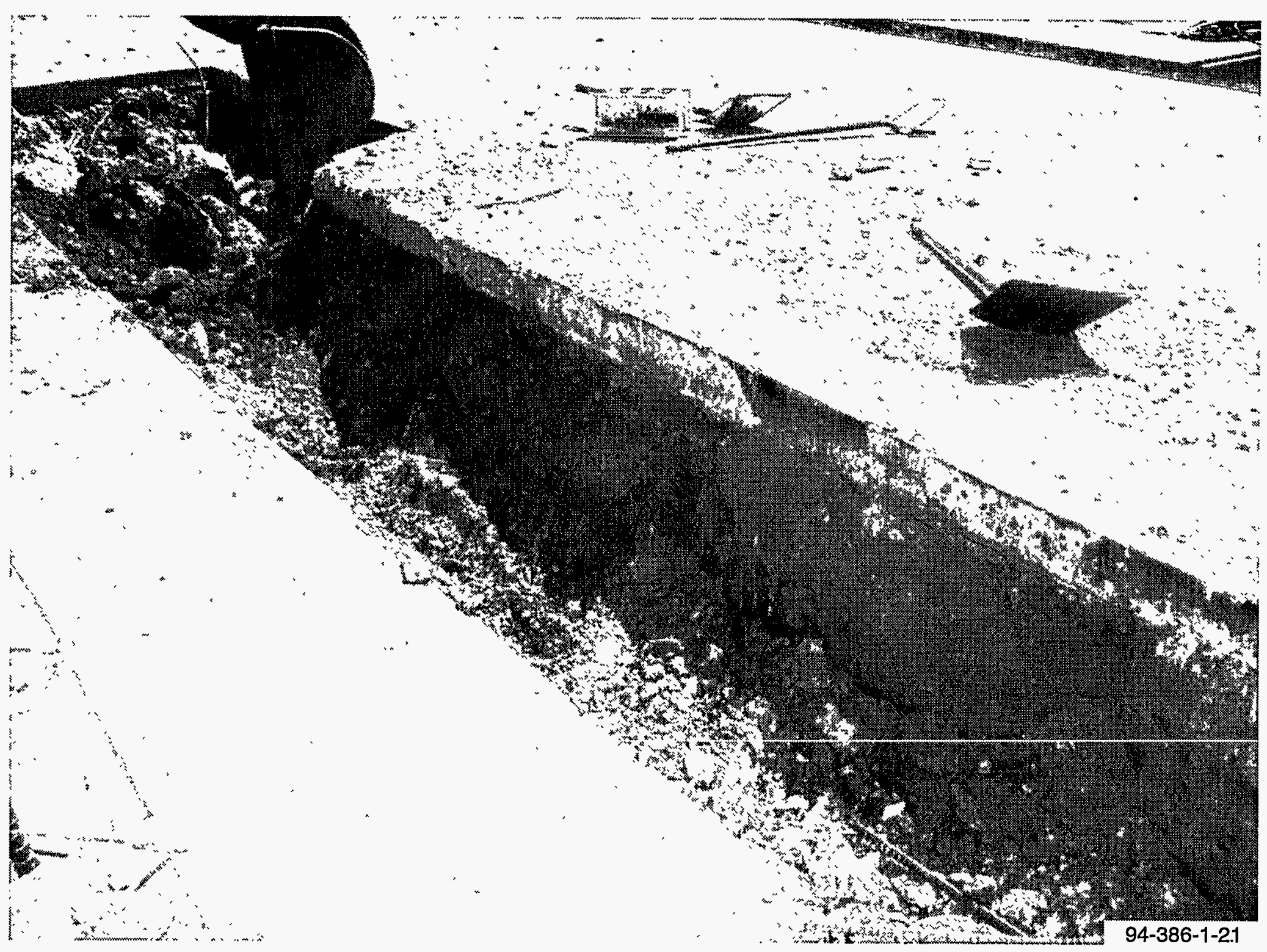

Figure 43. Contaminated soil being removed from beneath the concrete trench in Room 108. 


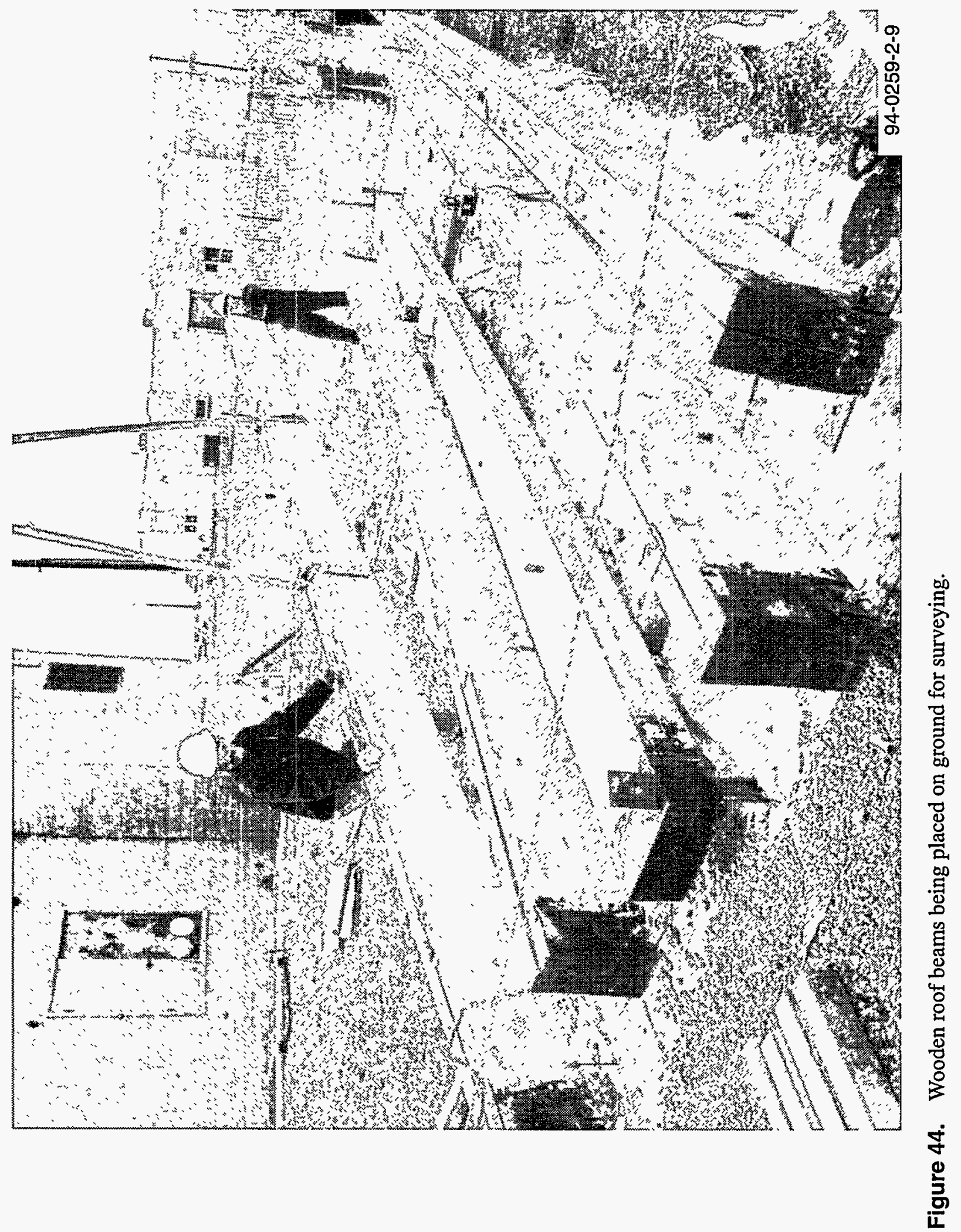









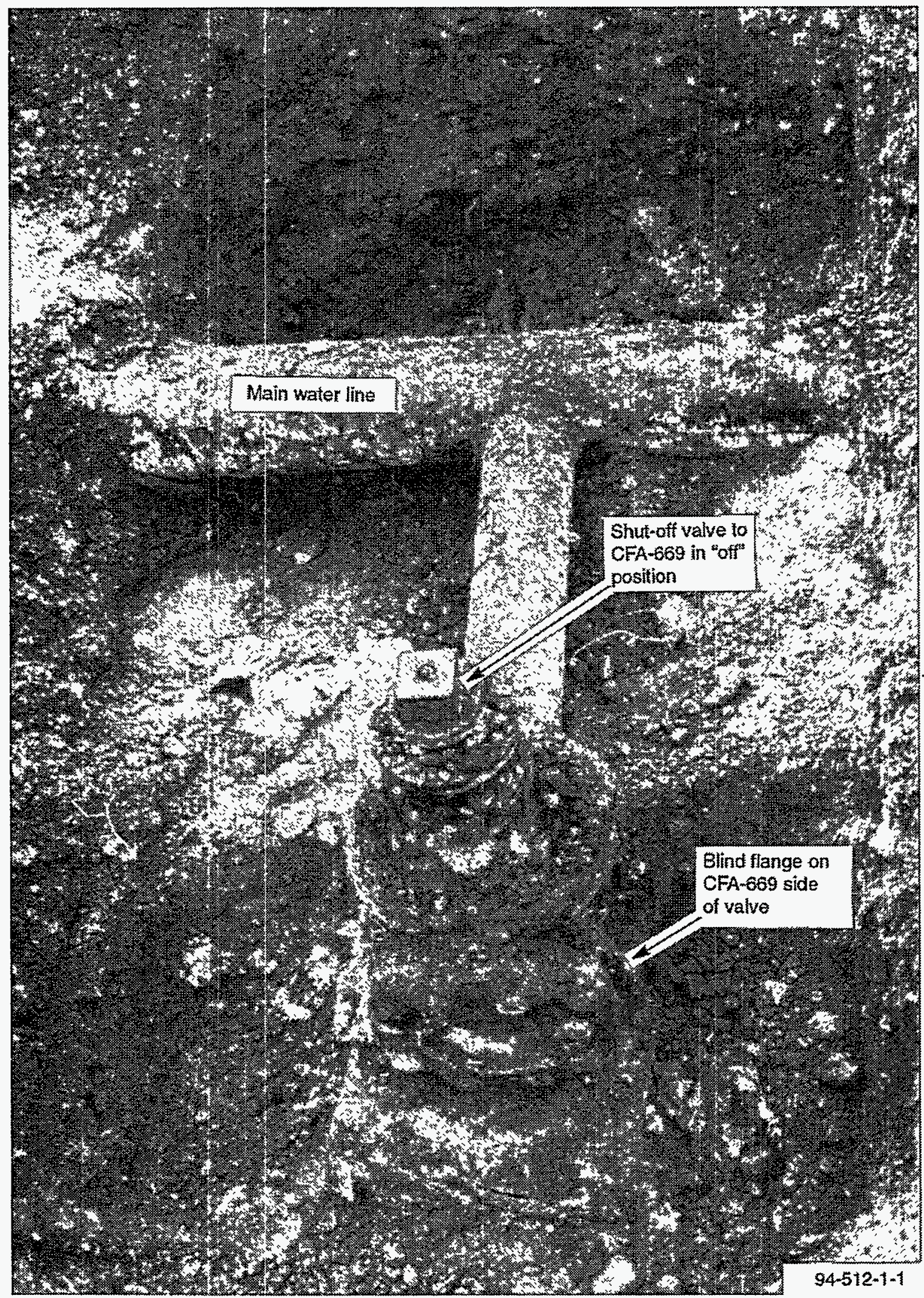

Figure 46. The water valve remaining after removal of the pipe section between the valve and CFA-669. 


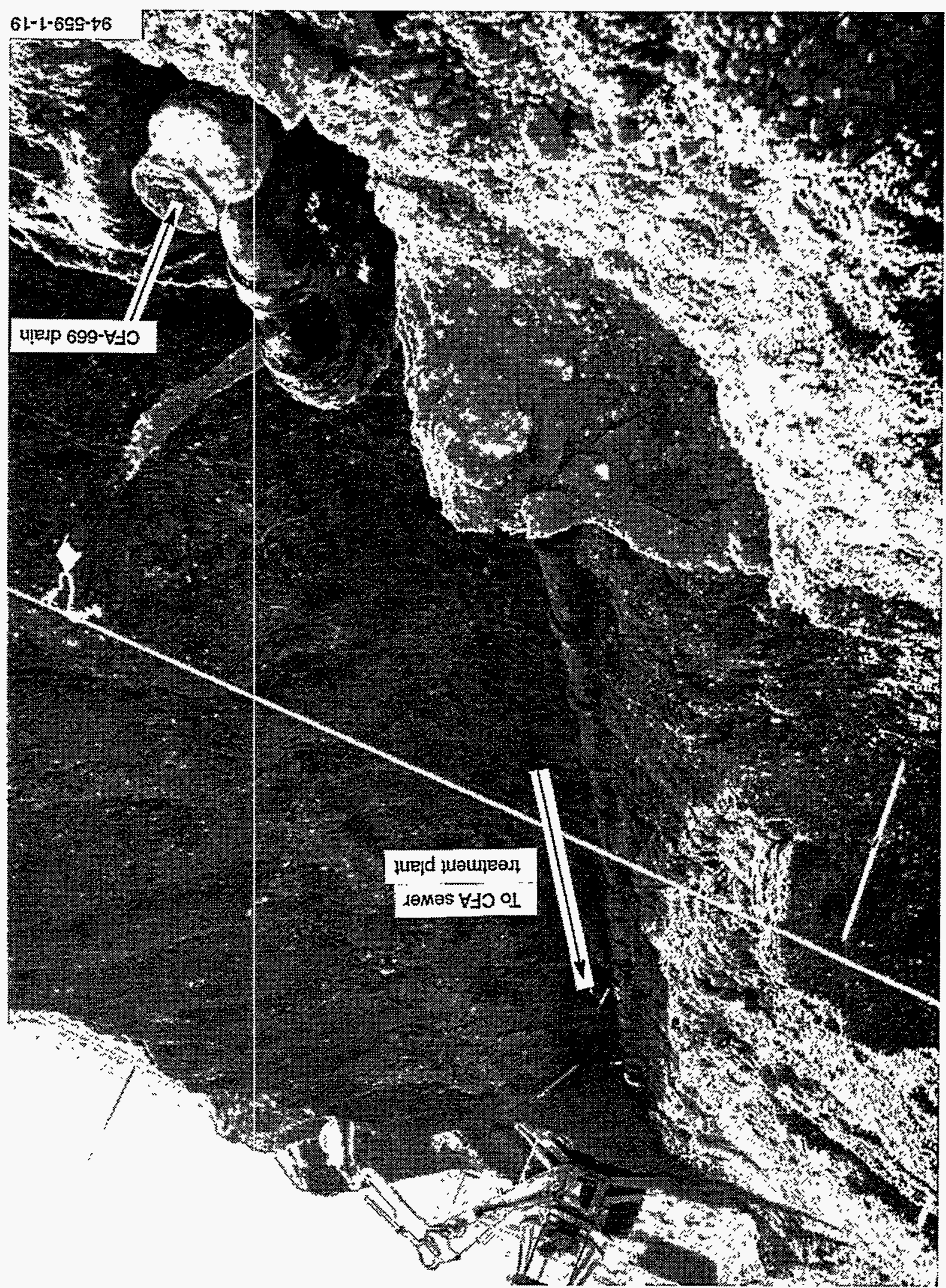




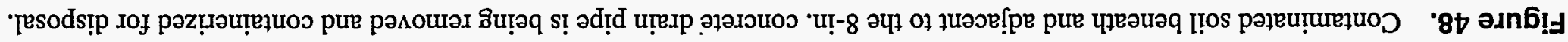

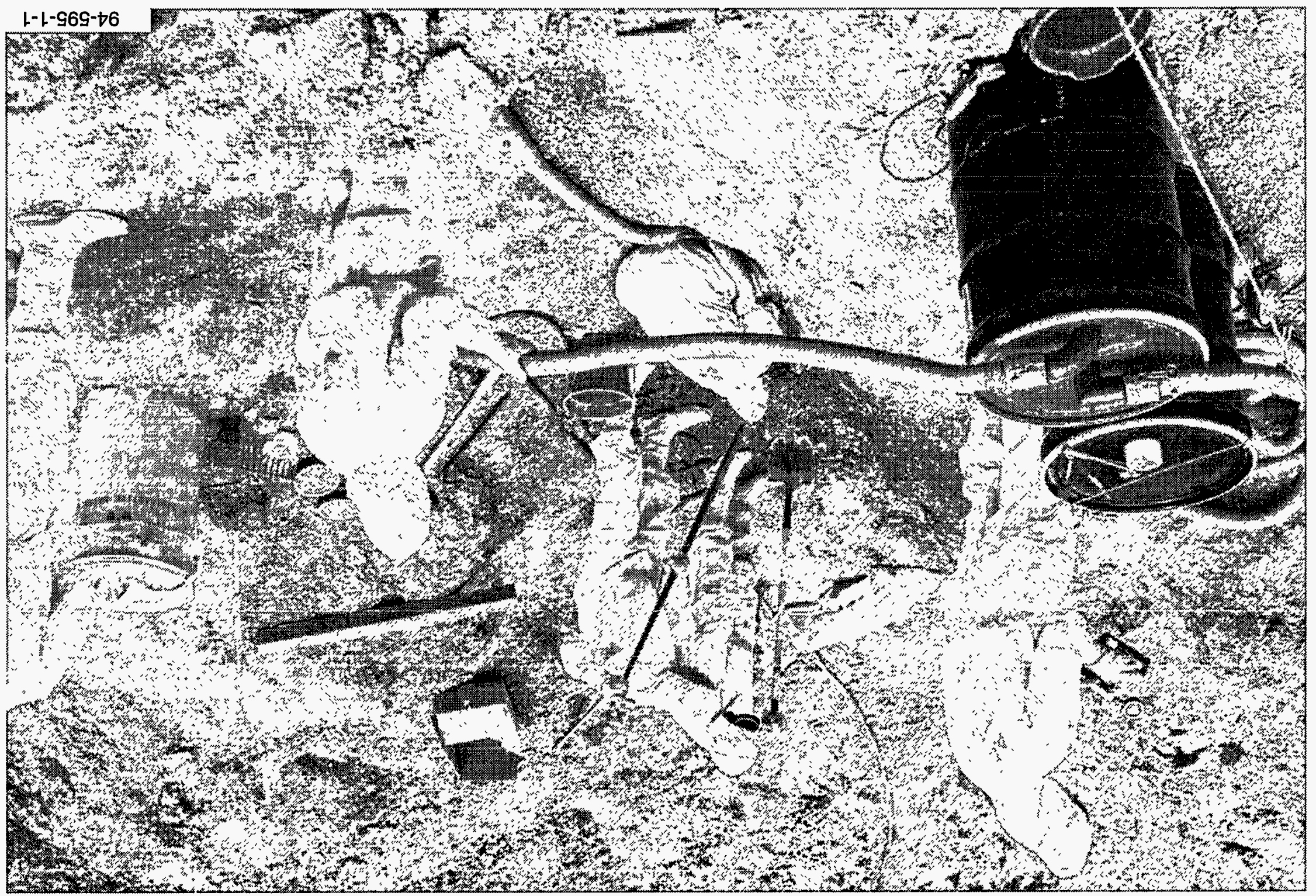




\subsection{Post-D\&D Activities}

3.3.1 Preparation of Post-D\&D Characterization Plans. Two post-D\&D characterization plans were prepared to specify the sampling and analyses and the radiological surveys for determining the post-D\&D condition of the CFA-669 site. The first plan prepared is Reference 7. This plan specified general characterization requirements. Details of sampling and analyses requirements were specified in Reference 8.

\subsubsection{Performance of Post-D\&D Charac-} terization. The post-D\&D characterization was performed after all radioactively contaminated soil (detectable using field instruments) was removed.

The post-D\&D characterization was performed in two phases. Phase I consisted of sampling and analysis of the trench and berm formed during excavation of the 8-in. contaminated sewer line. In addition, the trench formed during excavation of the soil beneath the concrete trench in Room 108 (Figure 43) was sampled and analyzed. Phase II characterization consisted of sampling and analysis of the entire CFA-669 site following backfilling of the trenches and gridding of the area. In addition, an area survey for betagamma radioactivity was performed.
Analyses of soil samples from both phases consisted of TCLP metals, volatile organic analysis (VOA), semi-VOA, gamma spectrum analysis, Sr-90, and alpha spectrum analysis. The results of Phase I and II analyses are given in Reference 9 and summarized in Section 7 of this final report.

\subsubsection{Preparation of Site for Seeding (and} Seeded the Area). Preparation of the CFA-669 site for seeding consisted of hauling in topsoil, grading the area, and applying fertilizer to enhance the growth of a select mixture of grass seed. Figure 49 shows topsoil being graded.

Following preparation of the soil area, a seedmulch-water mixture was hydraulically applied to the topsoil.

The area was fertilized with mono-ammonium phosphate 11-52-0 fertilizer specified by the CFA Environmental Coordinator.

The mulch was Silva-Fiber, $100 \%$ virgin wood fiber for hydraulic planting, made by Weyerhaeuser Corp. The seed-mulch-water mixture was applied using the Hydroseeder Finn Model T-170. Figure 50 is a photo of the CFA-669 site being hydroseeded. 


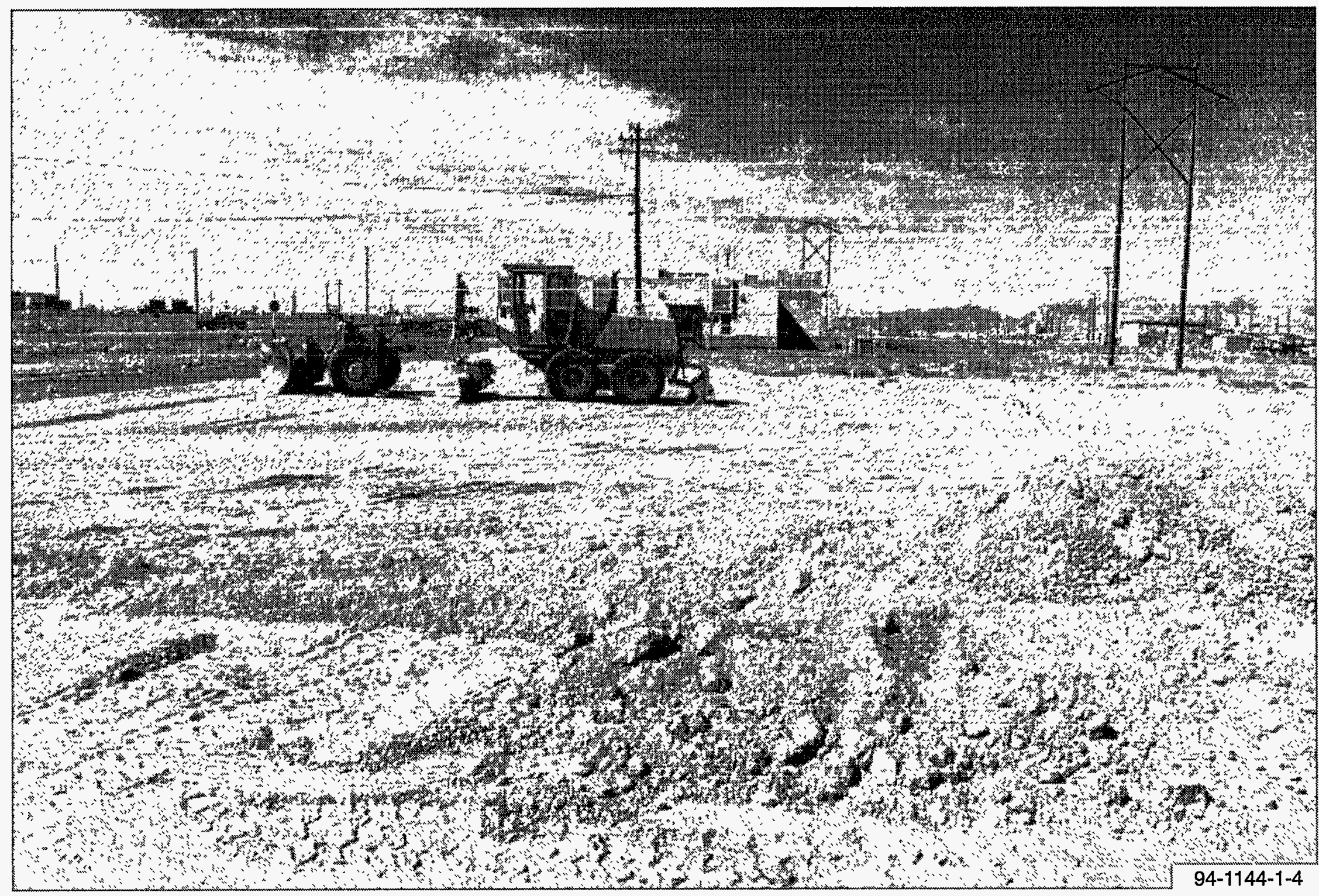

Figure 49. Topsoil was hauled to the CFA-669 site and graded in preparation for hydroseeding. 


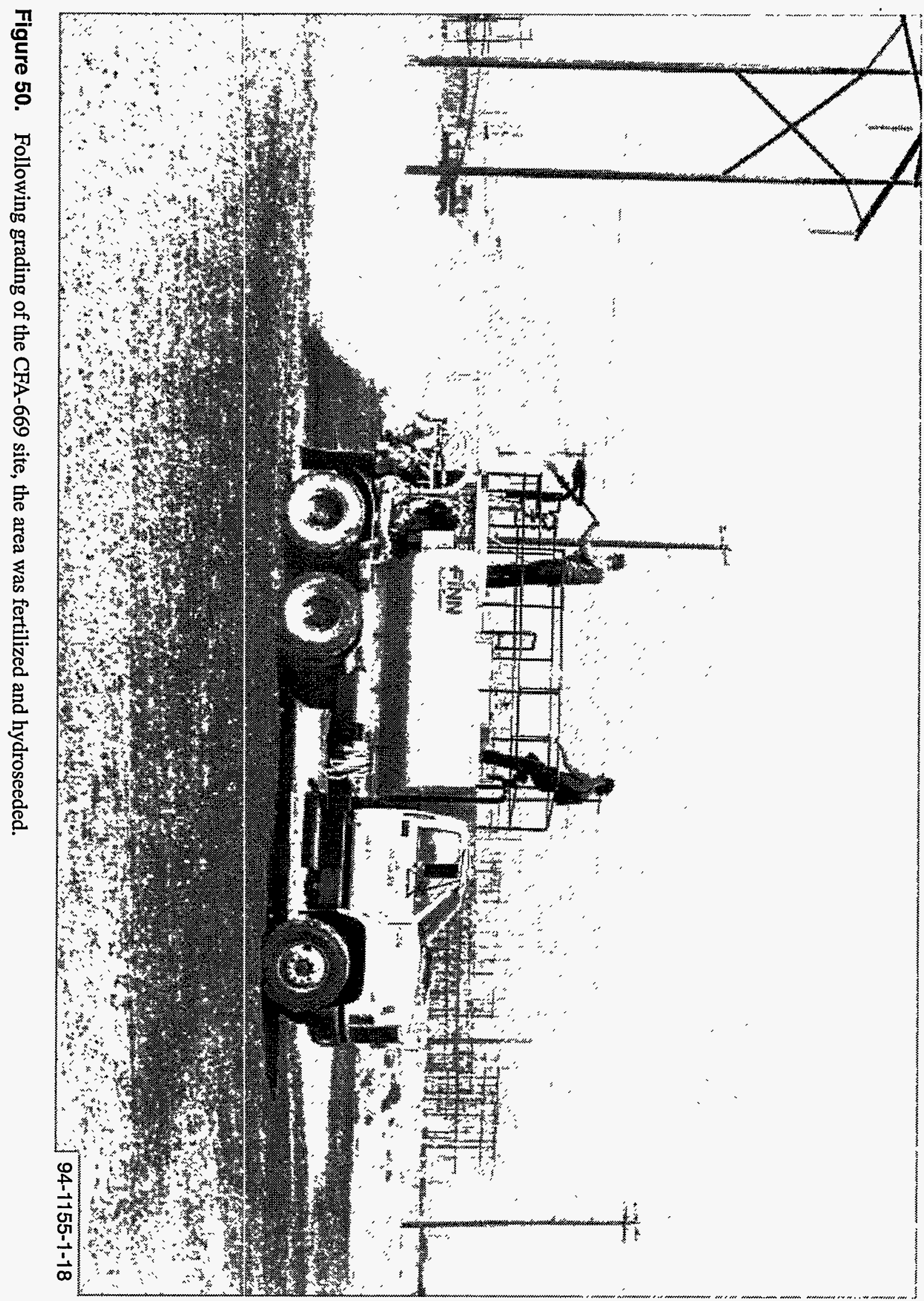




\section{COST AND SCHEDULE}

Each major-activity cost is shown in Figure 51. Total cost for all activities shown in Figure 51 is $\$ 2.8$ million, which includes both labor and nonlabor dollars. The project schedule (from initial planning through post-D\&D activities) is also shown in Figure 51. Only major project activities are shown.

The Project was completed 9 months ahead of schedule and approximately $\$ 140 \mathrm{~K}$ under budget. 


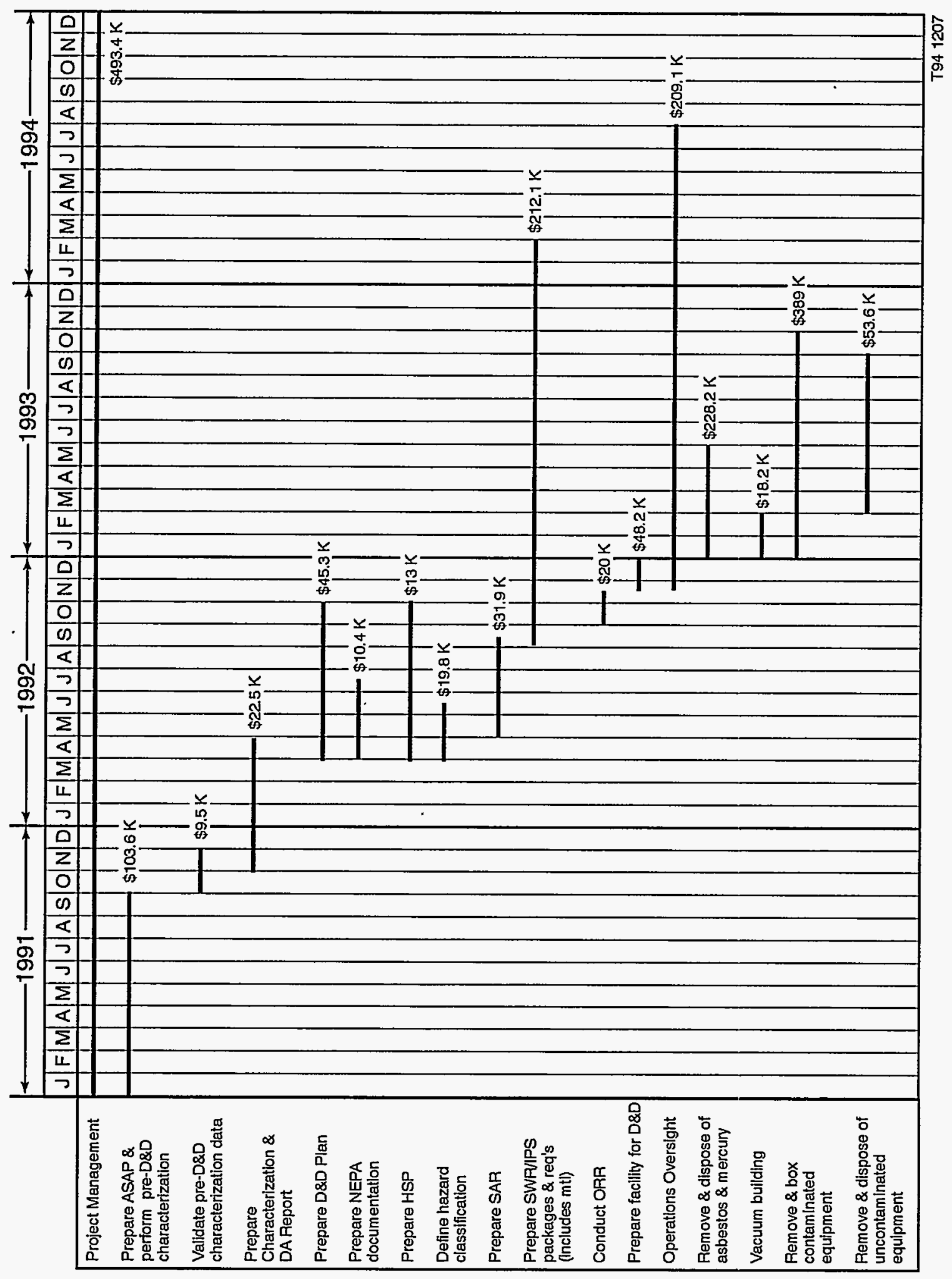

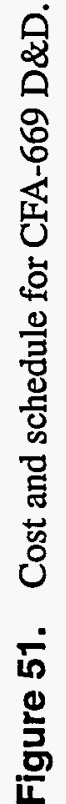




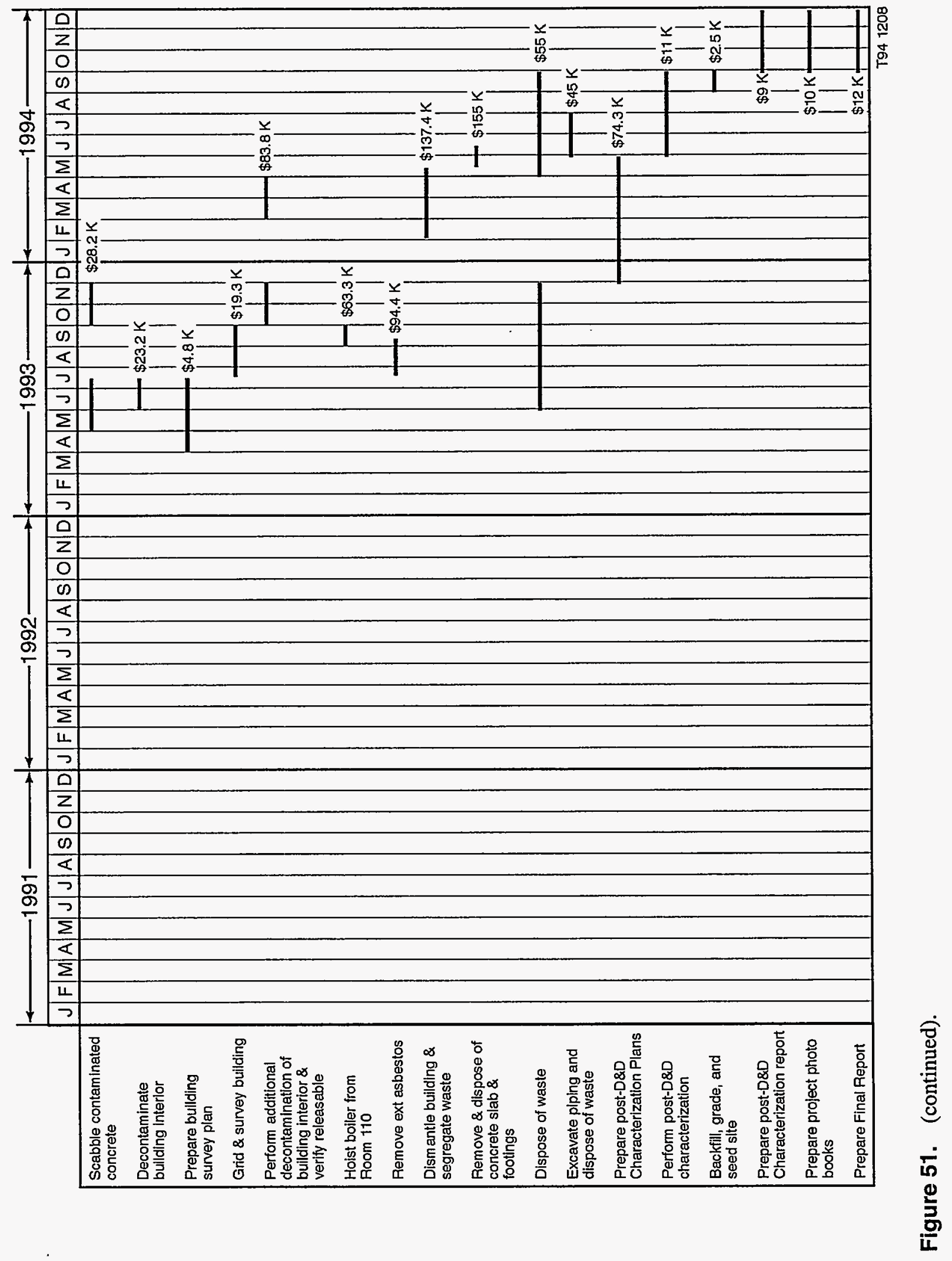




\section{VOLUME OF WASTE GENERATED}

Most waste generated during CFA-669 D\&D was uncontaminated and therefore disposed of in the CFA landfill.

Radioactive waste was disposed of at either the RWMC or WERF. Hazardous waste was shipped to the Hazardous Waste Facility at CFA.

No mixed waste was generated during CFA-669 D\&D.
Waste types, volumes, and disposition are summarized in Table 3. The volume of radioactive waste was above estimated amounts by a factor of 10 .

In addition to wastes generated during CFA-669 D\&D, several items were excessed for recycling or reuse. These items are summarized in Table 4.

Table 3. Waste generated during CFA-669 D\&D.

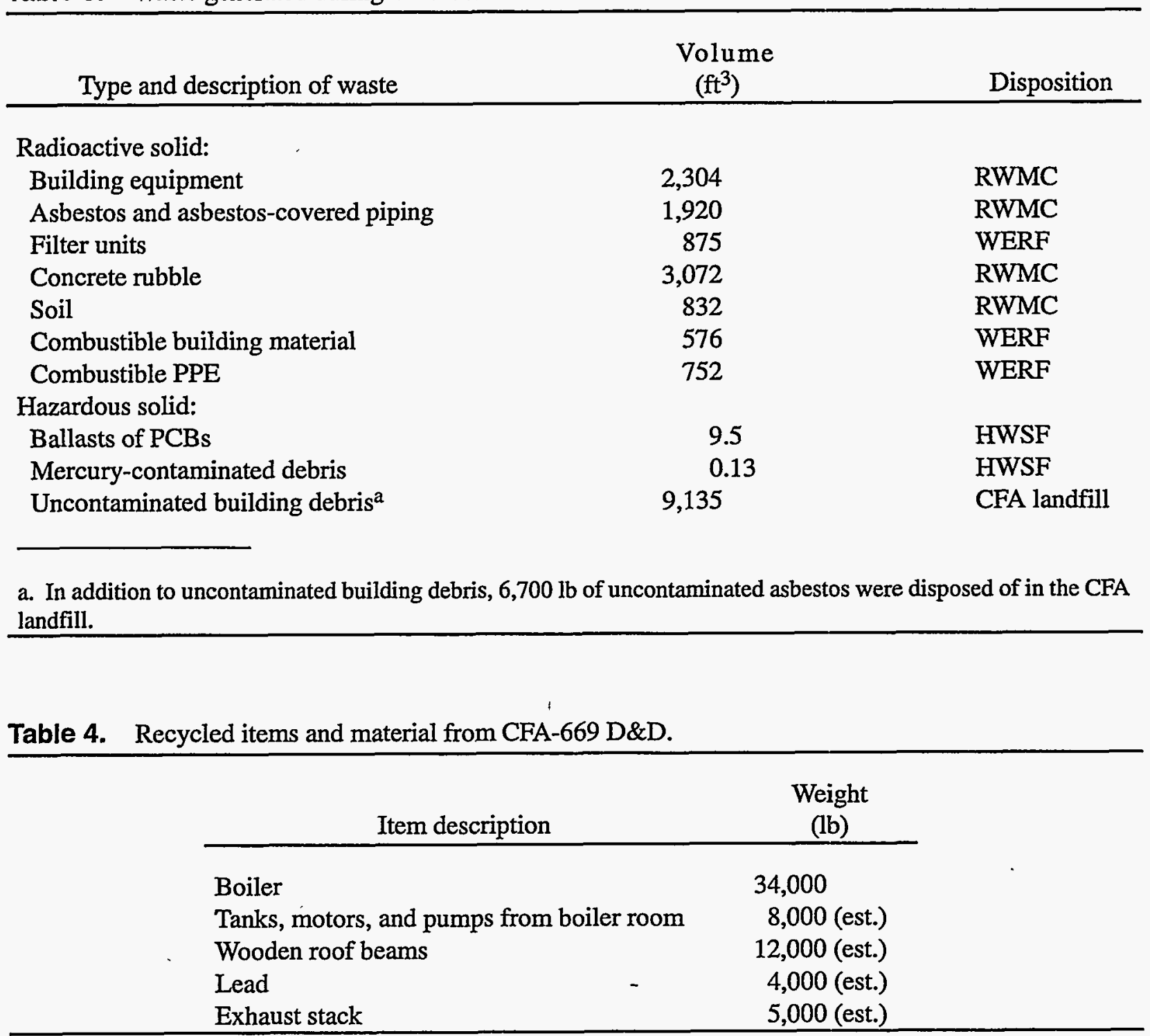




\section{PERSONNEL EXPOSURE}

Personnel involved in D\&D activities that could cause radiation exposure were required to wear thermoluminescent dosimeters (TLDs) to measure any radiation exposure. The TLDs were collected monthly and sent to the EG\&G Idaho Operational Dosimetry Unit for dose measurements.

Personnel exposure for this project was determined by requesting historical exposure records from the EG\&G Idaho Operational Dosimetry Unit. The records of 18 selected individuals were requested (by name and S-number) for the time during which each worked at CFA-669 and performed tasks that might have produced exposure. Selection of individuals and potential radiation exposure periods was based on a review of daily logs and weekly reports recorded during the entire project.

The Dosimetry Unit report indicated that each selected CFA-669 D\&D worker received a monthly dose of less than 10 mrem. A dose less than 10 mrem on individual TLDs is reported as zero by the Dosimetry Unit. 


\section{POST-D\&D CONDITION}

This section describes the current physical, radiological, and chemical condition of the CFA-669 site.

\subsection{Physical Condition}

Following completion of $D \& D$ and post-D\&D characterization, the soil area was backfilled and hydroseeded with the following grass mixture:

- P-27 Siberian wheatgrass

- "Sodar" streambank wheatgrass

- "Dealar" small burnet

- Lewis flax

- Alfalfa.

The post-D\&D physical condition following completion of hydroseeding is shown in Figure 52 by comparing " $a$ " and " $b$ " photographs.

\subsection{Radiological Condition}

Tables 5 through 8 summarize the results of Phases I and II post-D\&D radiological characterization. The details of the post-D\&D characterization are given in Reference 9. The highest specific activity of each detected radionuclide for both phases was entered into the DOE-recommended Residual Radioactivity
(RESRAD) computer program, Version 3.121. This computer program calculates the total effective dose equivalent to a member of a critical population group, from all external and internal pathways, as a result of any residual radioactivity in the soil.

The maximum total dose according to the RESRAD analysis would be $18 \mathrm{mrem} / \mathrm{year}$ for the CFA-669 site.

According to DOE Order 5400.5 guidelines, a soil area can be released for unrestricted use if the total dose does not exceed $100 \mathrm{mrem} /$ year.

The RESRAD site-release analysis for the CFA-669 site is documented in EDF-ER-21, CFA-669 RESRAD Site Release Analysis.

\subsection{Chemical Condition}

The post-D\&D characterization included sampling and analyses for TCLP metals, TCLP VOCs, and TCLP semi-VOCs. Results of the analyses were validated by the EG\&G Idaho Sample Management Office and reviewed by the Lockheed Idaho Technologies Company Environmental Monitoring. The review indicated that all contaminant concentrations were below the regulatory level found in 40 CFR 261.24, Table 1. Analytical and validation results are on file at the Environmental Restoration Administrative Record and Document Control. 


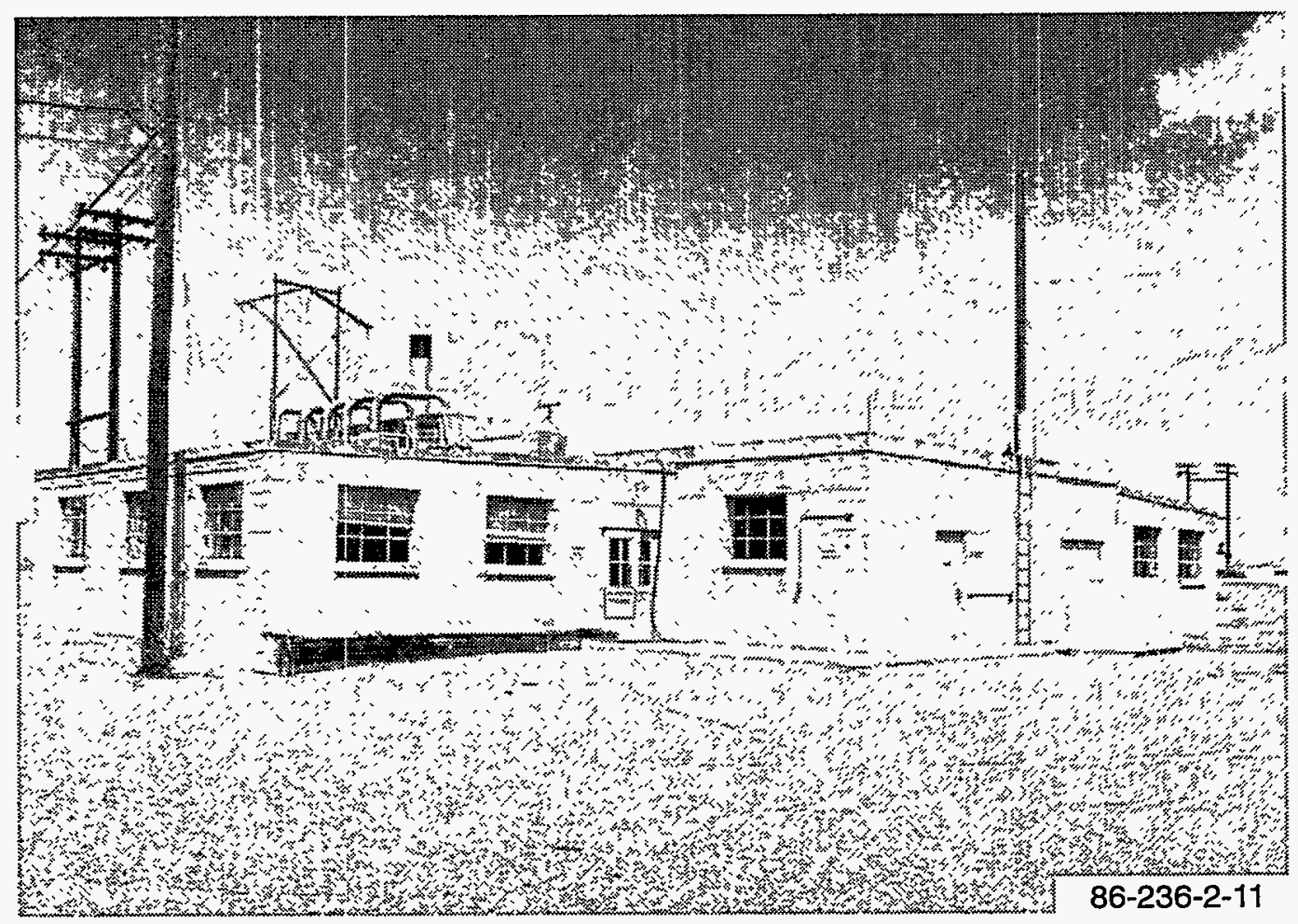

(a)

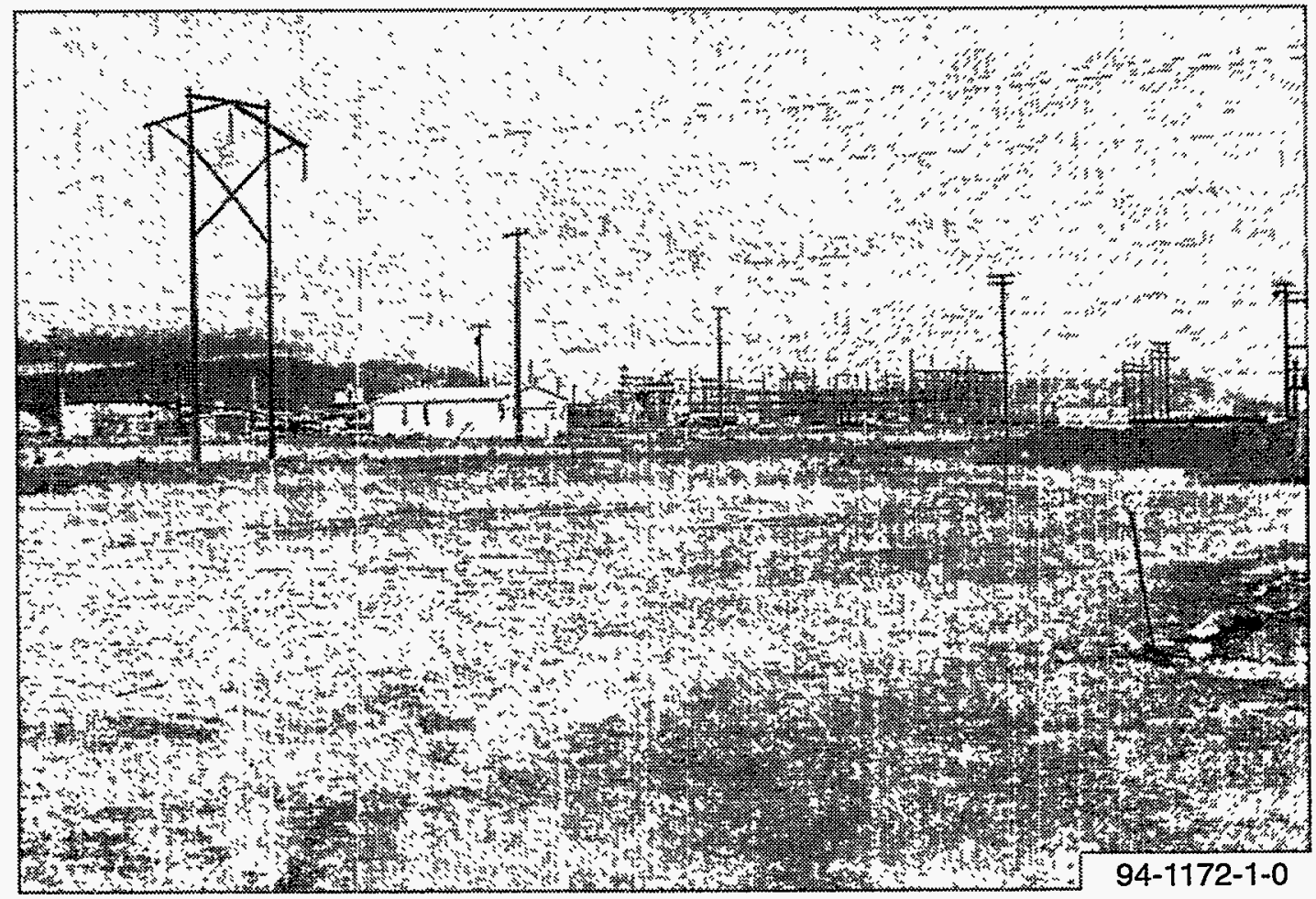

(b)

Figure 52. A comparison of CFA-669 "before" and "after" completion of D\&D. 
Table 5. Results of Phase I gamma spectrum analyses.

\begin{tabular}{rll} 
Sample number & $\begin{array}{c}\text { Manmade } \\
\text { radionuclides }\end{array}$ & $\begin{array}{c}\text { Specific activity } \\
(\mathrm{pCi} / \mathrm{g})\end{array}$ \\
\hline 02106279401 & None detected & $\mathrm{N} / \mathrm{A}$ \\
02 & Co-60 & $5.8 \pm 1.4 \mathrm{E}-02$ \\
& Cs-137 & $6.1 \pm 0.5 \mathrm{E}-01$ \\
03 & Cs-137 & $3.7 \pm 0.4 \mathrm{E}-01$ \\
04 & Cs-137 & $7.2 \pm 0.7 \mathrm{E}-01$ \\
05 & Co-60 & $5.9 \pm 1.4 \mathrm{E}-02$ \\
& Cs-137 & $3.7 \pm 0.4 \mathrm{E}-01$ \\
06 & Co-60 & $9.0 \pm 0.7 \mathrm{E}-01$ \\
& Cs-137 & $5.7 \pm 0.6 \mathrm{E}-01$ \\
07 & None detected & N/A \\
09 & Cs-137 & $7.9 \pm 0.8 \mathrm{E}-01$ \\
10 & Cs-137 & $2.1 \pm 0.4 \mathrm{E}-01$ \\
11 & Cs-137 & $6.0 \pm 2.0 \mathrm{E}-02$ \\
12 & Cs-137 & $3.2 \pm 0.5 \mathrm{E}-01$ \\
13 & Cs-137 & $1.5 \pm 0.2 \mathrm{E}-01$ \\
14 & None detected & N/A \\
15 & Cs-137 & $1.2 \pm 0.2 \mathrm{E}-01$ \\
16 & Cs-137 & $2.4 \pm 0.3 \mathrm{E}-01$ \\
17 & None detected & N/A \\
18 & Co-60 & $4.7 \pm 1.2 \mathrm{E}-02$ \\
& Cs-137 & $1.96 \pm 0.18$ \\
& Eu-152 & E-00 \\
20 & None detected & $2.1 \pm 0.3 \mathrm{E}-01$ \\
21 & None detected & N/A \\
& &
\end{tabular}

1. A "None detected" under "Manmade Radionuclides" means that the analyst determined that no manmade truepositive radionuclides were present in the respective sample(s).

2. The uncertainty associated with any reported activity includes the statistical uncertainty and estimated uncertainties in the detector efficiency and the sample geometry (both are typically 5\%). Uncertainties are propagated in quadrature and expressed as one standard deviation.

3. When a sample's matrix differs radically from that of the calibration standard used by the Radiation Measurements Laboratory, the measured activity may not accurately represent the true radionuclide concentration in that sample. In such cases, a non-zero estimated bias is applied in place of the estimated sample geometry; this bias is not propagated into the total uncertainty and is listed separately. 
Table 6. Results of Phase I strontium-90 (Sr-90) and alpha spectrum analyses (pCi/g).

\begin{tabular}{|c|c|c|c|c|c|c|c|c|c|c|c|c|c|}
\hline $\begin{array}{l}\text { Sample } \\
\text { number }\end{array}$ & ${ }^{241} \mathrm{Am}$ & ${ }^{243} \mathrm{Am}$ & ${ }^{242} \mathrm{Cm}$ & ${ }^{244} \mathrm{Cm}$ & ${ }^{238} \mathrm{Pu}$ & ${ }^{239 / 240} \mathrm{Pu}$ & ${ }^{234} \mathrm{U}$ & ${ }^{235} \mathrm{U}$ & ${ }^{238} \mathrm{U}$ & ${ }^{228} \mathrm{Th}$ & ${ }^{230} \mathrm{Th}$ & ${ }^{232} \mathrm{Th}$ & Sr-90 \\
\hline 02106279401 & $\mathbf{U}$ & $\mathrm{U}$ & U & $\mathbf{U}$ & $\mathrm{U}$ & $\mathrm{U}$ & $\begin{array}{l}1.077 \\
\pm 0.149\end{array}$ & $\begin{array}{l}0.043 \\
\pm 0.017\end{array}$ & $\begin{array}{l}1.095 \\
\pm 0.151\end{array}$ & $\begin{array}{l}1.315 \\
\pm 0.188\end{array}$ & $\begin{array}{l}1.227 \\
\pm 0.175\end{array}$ & $\begin{array}{l}1.306 \\
\pm 0.186\end{array}$ & $\mathrm{U}$ \\
\hline 02106279402 & $\mathbf{U}$ & $\mathbf{U}$ & $\mathrm{U}$ & $\mathbf{U}$ & $\mathrm{U}$ & $\mathrm{U}$ & $\begin{array}{l}1.293 \\
\pm 0.179\end{array}$ & $\begin{array}{l}0.056 \\
\pm 0.019\end{array}$ & $\begin{array}{l}1.351 \\
\pm 0.182\end{array}$ & $\begin{array}{l}1.365 \\
\pm 0.199\end{array}$ & $\begin{array}{l}1.291 \\
\pm 0.189\end{array}$ & $\begin{array}{l}1.311 \\
\pm 0.191\end{array}$ & $7 \pm 3 \mathrm{E}-01$ \\
\hline 02106279403 & $\mathbf{U}$ & $\mathrm{U}$ & $\mathrm{U}$ & $\mathrm{U}$ & $\begin{array}{l}0.054 \\
\pm 0.019\end{array}$ & $\mathrm{U}$ & $\begin{array}{l}1.167 \\
\pm 0.161\end{array}$ & $\begin{array}{l}0.054 \\
\pm 0.017\end{array}$ & $\begin{array}{l}1.261 \\
\pm 0.172\end{array}$ & $\begin{array}{l}1.372 \\
\pm 0.196\end{array}$ & $\begin{array}{l}1.396 \\
\pm 0.198\end{array}$ & $\begin{array}{l}1.358 \\
\pm 0.193\end{array}$ & $1.3 \pm 0.4 \mathrm{E}+00$ \\
\hline 02106279404 & $\mathrm{U}$ & $\mathrm{U}$ & U & $\mathrm{U}$ & $\begin{array}{l}0.065 \\
\pm 0.026\end{array}$ & $\begin{array}{l}0.009 \\
\pm 0.007\end{array}$ & $\begin{array}{l}1.002 \\
\pm 0.148\end{array}$ & $\begin{array}{l}0.043 \\
\pm 0.019\end{array}$ & $\begin{array}{l}1.086 \\
\pm 0.158\end{array}$ & $\begin{array}{l}1.403 \\
\pm 0.200\end{array}$ & $\begin{array}{l}1.313 \\
\pm 0.187\end{array}$ & $\begin{array}{l}1.336 \\
\pm 0.191\end{array}$ & $8 \pm 3 \mathrm{E}-01$ \\
\hline 02106279405 & UJ & $\mathbf{U}$ & $\mathrm{U}$ & $\mathbf{U}$ & $\mathbf{U}$ & $\mathrm{U}$ & $\begin{array}{l}1.140 \\
\pm 0.158\end{array}$ & $\begin{array}{l}0.043 \\
\pm 0.017\end{array}$ & $\begin{array}{l}1.205 \\
\pm 0.166\end{array}$ & $\begin{array}{l}1.385 \\
\pm 0.197\end{array}$ & $\begin{array}{l}1.284 \\
\pm 0.183\end{array}$ & $\begin{array}{l}1.300 \\
\pm 0.186\end{array}$ & $9 \pm 4 \mathrm{E}-01$ \\
\hline 02106279406 & $\mathrm{U}$ & $U$ & $U$ & $U$ & $\mathrm{U}$ & $\mathrm{U}$ & $\begin{array}{l}1.061 \\
\pm 0.147\end{array}$ & $\begin{array}{l}0.056 \\
\pm 0.017\end{array}$ & $\begin{array}{l}1.063 \\
\pm 0.147\end{array}$ & $\begin{array}{l}1.358 \\
\pm 0.198\end{array}$ & $\begin{array}{l}1.257 \\
\pm 0.185\end{array}$ & $\begin{array}{l}1.396 \\
\pm 0.203\end{array}$ & $1.3 \pm 0.3 \mathrm{E}+00$ \\
\hline 02106279407 & $\mathrm{U}$ & $\mathbf{U}$ & $\mathrm{U}$ & $\mathrm{U}$ & $\mathbf{U}$ & $U$ & $\begin{array}{l}1.169 \\
\pm 0.159\end{array}$ & $\begin{array}{l}0.047 \\
\pm 0.017\end{array}$ & $\begin{array}{l}1.115 \\
\pm 0.152\end{array}$ & $\begin{array}{l}1.414 \\
\pm 0.202\end{array}$ & $\begin{array}{l}1.300 \\
\pm 0.186\end{array}$ & $\begin{array}{l}1.437 \\
\pm 0.204\end{array}$ & $1.6 \pm 0.4 \mathrm{E}+00$ \\
\hline 02106279409 & $U$ & $\mathrm{U}$ & $\mathrm{U}$ & $\mathrm{U}$ & $\mathbf{U}$ & $\mathrm{U}$ & $\begin{array}{l}1.482 \\
\pm 0.205\end{array}$ & $\begin{array}{l}0.072 \\
\pm 0.024\end{array}$ & $\begin{array}{l}1.270 \\
\pm 0.178\end{array}$ & $\begin{array}{l}1.592 \\
\pm 0.223\end{array}$ & $\begin{array}{l}1.426 \\
\pm 0.202\end{array}$ & $\begin{array}{l}1.529 \\
\pm 0.215\end{array}$ & $3.4 \pm 0.4 \mathrm{E}+00$ \\
\hline 02106279410 & $U$ & $\mathbf{U}$ & $\begin{array}{l}0.032 \\
\pm 0.016\end{array}$ & $\mathrm{U}$ & U & $\mathrm{U}$ & $\begin{array}{l}1.216 \\
\pm 0.165\end{array}$ & $\begin{array}{l}0.063 \\
\pm 0.019\end{array}$ & $\begin{array}{l}1.273 \\
\pm 0.171\end{array}$ & $\begin{array}{l}2.347 \\
\pm 0.338\end{array}$ & $\begin{array}{l}2.232 \\
\pm 0.322\end{array}$ & $\begin{array}{l}2.304 \\
\pm 0.333\end{array}$ & $1.3 \pm 0.4 \mathrm{E}+00$ \\
\hline 02106279411 & U & $\mathbf{U}$ & $\begin{array}{l}0.050 \\
\pm 0.019\end{array}$ & $\mathrm{U}$ & U & $\mathrm{U}$ & $\begin{array}{l}1.309 \\
\pm 0.174\end{array}$ & $\begin{array}{l}0.068 \\
\pm 0.018\end{array}$ & $\begin{array}{l}1.234 \\
\pm 0.165\end{array}$ & $\begin{array}{l}1.462 \\
\pm 0.211\end{array}$ & $\begin{array}{l}1.349 \\
\pm 0.195\end{array}$ & $\begin{array}{l}1.511 \\
\pm 0.217\end{array}$ & $2.1 \pm 0.4 \mathrm{E}+00$ \\
\hline 02106279412 & UJ & $\begin{array}{l}0.014 \\
\pm 0.007\end{array}$ & $\begin{array}{l}0.032 \\
\pm 0.016\end{array}$ & $\mathrm{U}$ & $\mathbf{U}$ & $\mathrm{U}$ & $\begin{array}{l}1.164 \\
\pm 0.155\end{array}$ & $\begin{array}{l}0.047 \\
\pm 0.015\end{array}$ & $\begin{array}{l}1.212 \\
\pm 0.161\end{array}$ & $\begin{array}{l}1.464 \\
\pm 0.229\end{array}$ & $\begin{array}{l}1.336 \\
\pm 0.209\end{array}$ & $\begin{array}{l}1.300 \\
\pm 0.205\end{array}$ & $3.3 \pm 0.6 \mathrm{E}+00$ \\
\hline 02106279413 & UJ & $\begin{array}{l}0.016 \\
\pm 0.009\end{array}$ & $\mathrm{U}$ & $\mathrm{U}$ & $\begin{array}{l}0.020 \\
\pm 0.009\end{array}$ & U & $\begin{array}{l}1.405 \\
\pm 0.183\end{array}$ & $\begin{array}{l}0.070 \\
\pm 0.018\end{array}$ & $\begin{array}{l}1.243 \\
\pm 0.164\end{array}$ & $\begin{array}{l}1.300 \\
\pm 0.208\end{array}$ & $\begin{array}{l}1.225 \\
\pm 0.195\end{array}$ & $\begin{array}{l}1.261 \\
\pm 0.200\end{array}$ & $5.9 \pm 0.6 \mathrm{E}+00$ \\
\hline 02106279414 & $\mathrm{~J}$ & $\begin{array}{l}0.007 \\
\pm 0.005\end{array}$ & $\begin{array}{l}0.043 \\
\pm 0.014\end{array}$ & $\begin{array}{l}0.041 \\
\pm 0.016\end{array}$ & $\begin{array}{l}0.032 \\
\pm 0.018\end{array}$ & $U$ & $\begin{array}{l}1.450 \\
\pm 0.194\end{array}$ & $\begin{array}{l}0.086 \\
\pm 0.023\end{array}$ & $\begin{array}{l}1.351 \\
\pm 0.182\end{array}$ & $\begin{array}{l}1.559 \\
\pm 0.239\end{array}$ & $\begin{array}{l}1.387 \\
\pm 0.214\end{array}$ & $\begin{array}{l}1.502 \\
\pm 0.230\end{array}$ & $1.2 \pm 0.4 \mathrm{E}+00$ \\
\hline 02106279415 & $\mathrm{~J}$ & $\mathbf{U}$ & U & $U$ & $\mathbf{U}$ & $U$ & $\begin{array}{l}1.396 \\
\pm 0.187\end{array}$ & $\begin{array}{l}0.056 \\
\pm 0.019\end{array}$ & $\begin{array}{l}1.387 \\
\pm 0.186\end{array}$ & $\begin{array}{l}1.347 \\
\pm 0.215\end{array}$ & $\begin{array}{l}1.302 \\
\pm 0.208\end{array}$ & $\begin{array}{l}1.336 \\
\pm 0.212\end{array}$ & U \\
\hline 02106279416 & $\mathbf{J}$ & $\begin{array}{l}0.014 \\
\pm 0.009\end{array}$ & $\begin{array}{l}0.036 \\
\pm 0.016\end{array}$ & U & $\begin{array}{l}0.043 \\
\pm 0.021\end{array}$ & $\begin{array}{l}0.011 \\
\pm 0.011\end{array}$ & $\begin{array}{l}1.248 \\
\pm 0.168\end{array}$ & $\begin{array}{l}0.059 \\
\pm 0.017\end{array}$ & $\begin{array}{l}1.189 \\
\pm 0.161\end{array}$ & $\begin{array}{l}1.667 \\
\pm 0.259\end{array}$ & $\begin{array}{l}1.293 \\
\pm 0.205\end{array}$ & $\begin{array}{l}1.514 \\
\pm 0.237\end{array}$ & $3.7 \pm 0.8 \mathrm{E}+00$ \\
\hline 02106279417 & UJ & $u$ & $\mathbf{U}$ & $\mathrm{U}$ & $\mathbf{U}$ & $\mathrm{U}$ & $\begin{array}{l}1.140 \\
\pm 0.153\end{array}$ & $\begin{array}{l}0.061 \\
\pm 0.017\end{array}$ & $\begin{array}{l}1.225 \\
\pm 0.163\end{array}$ & $\begin{array}{l}1.802 \\
\pm 0.275\end{array}$ & $\begin{array}{l}1.437 \\
\pm 0.224\end{array}$ & $\begin{array}{l}1.646 \\
\pm 0.253\end{array}$ & $1.6 \pm 0.5 \mathrm{E}+00$ \\
\hline
\end{tabular}


Table 6. (continued).

\begin{tabular}{|c|c|c|c|c|c|c|c|c|c|c|c|c|c|}
\hline $\begin{array}{l}\text { Sample } \\
\text { number }\end{array}$ & ${ }^{241} \mathrm{Am}$ & ${ }^{243} \mathrm{Am}$ & ${ }^{242} \mathrm{Cm}$ & ${ }^{244} \mathrm{Cm}$ & ${ }^{238} \mathrm{Pu}$ & $239 / 240 \mathrm{Pu}$ & ${ }^{234} U$ & ${ }^{235} \mathrm{U}$ & ${ }^{238} \mathrm{U}$ & $228 \mathrm{Th}$ & ${ }^{230} \mathrm{Th}$ & ${ }^{232} \mathrm{Th}$ & $\mathrm{Sr}-90$ \\
\hline 02106279418 & UJ & $\mathbf{u}$ & $\begin{array}{l}0.038 \\
\pm 0.016\end{array}$ & $\begin{array}{l}0.027 \\
\pm 0.018\end{array}$ & $\mathbf{U}$ & $\mathrm{U}$ & $\begin{array}{l}1.498 \\
\pm 0.199\end{array}$ & $\begin{array}{l}0.074 \\
\pm 0.020\end{array}$ & $\begin{array}{l}1.248 \\
\pm 0.168\end{array}$ & $\begin{array}{l}1.491 \\
\pm 0.238\end{array}$ & $\begin{array}{l}1.475 \\
\pm 0.235\end{array}$ & $\begin{array}{l}1.446 \\
\pm 0.231\end{array}$ & $6.5 \pm 0.6 \mathrm{E}+00$ \\
\hline 02106279420 & UJ & U & $\begin{array}{l}0.038 \\
\pm 0.014\end{array}$ & $\begin{array}{l}0.020 \\
\pm 0.016\end{array}$ & $U$ & $\mathrm{U}$ & $\begin{array}{l}1.081 \\
\pm 0.144\end{array}$ & $\begin{array}{l}0.056 \\
\pm 0.0\end{array}$ & $\begin{array}{l}1.189 \\
\pm 0.159\end{array}$ & $\begin{array}{l}1.435 \\
\pm 0.210\end{array}$ & $\begin{array}{l}1.502 \\
\pm 0.217\end{array}$ & $\begin{array}{l}1.387 \\
\pm 0.202\end{array}$ & $1.7 \pm 0.4 \mathrm{E}+00$ \\
\hline 02106279421 & $\mathbf{U}$ & $\mathbf{U}$ & $\begin{array}{l}0.027 \\
\pm 0.014\end{array}$ & $\begin{array}{l}0.023 \\
\pm 0.016\end{array}$ & $\begin{array}{l}0.016 \\
\pm 0.009\end{array}$ & $\mathrm{U}$ & $\begin{array}{l}1.259 \\
\pm 0.170\end{array}$ & $\begin{array}{l}0.072 \\
\pm 0.020\end{array}$ & $\begin{array}{l}1.392 \\
\pm 0.187\end{array}$ & $\begin{array}{l}1.660 \\
\pm 0.240\end{array}$ & $\begin{array}{l}1.309 \\
\pm 0.192\end{array}$ & $\begin{array}{l}1.414 \\
\pm 0.206\end{array}$ & $2.2 \pm 0.4 \mathrm{E}+00$ \\
\hline
\end{tabular}

$\mathrm{U}=$ Result is a statistical nondetect at the $95 \%$ confidence level.

$\mathrm{J}=$ Result is considered to be an estimated quantity because of questionable or out-of-control quality control parameter. Result is statistically positive at the $95 \%$ confidence level.

UJ = Result does not meet the criteria for statistically positive value at the $95 \%$ confidence level and is considered to be an estimated quantity because of a questionable or out-of-control quality control parameter. 
Table 7. Results of Phase II gamma spectrum analysis.

\begin{tabular}{|c|c|c|}
\hline Sample ID & $\begin{array}{c}\text { Manmade } \\
\text { radionuclides }\end{array}$ & $\begin{array}{c}\text { Activity } \\
\text { (pCi/gram) }\end{array}$ \\
\hline 02108019401 & Cs-137 & $7.0 \pm 2.0 \mathrm{E}-02$ \\
\hline 02108019402 & Cs-137 & $6.4 \pm 1.9 \mathrm{E}-02$ \\
\hline 02108019403 & None detected ${ }^{\mathrm{a}}$ & N/A \\
\hline 02108019404 & None detected ${ }^{a}$ & N/A \\
\hline 02108019405 & Cs-137 & $3.1 \pm 0.3 \mathrm{E}-01$ \\
\hline 02108019405R & None detected ${ }^{\mathrm{a}}$ & N/A \\
\hline 02108019406 & Cs-137 & $2.0 \pm 0.4 \mathrm{E}-01$ \\
\hline 02108019407 & Cs-137 & $3.1 \pm 0.4 \mathrm{E}-01$ (highest) \\
\hline 02108019408 & Cs-137 & $2.4 \pm 0.3 \mathrm{E}-01$ \\
\hline 02108019409 & Cs-137 & $6.5 \pm 1.6 \mathrm{E}-02$ \\
\hline 02108019410 & Cs-137 & $9.0 \pm 2.0 \mathrm{E}-02$ \\
\hline 02108019411 & Co-60 & $9.5 \pm 1.8 \mathrm{E}-02$ (highest) \\
\hline 02108019412 & Co-60 & $9.4 \pm 1.8 \mathrm{E}-02$ \\
\hline 02108019413 & None detected ${ }^{\mathrm{a}}$ & N/A \\
\hline 02108019414 & None detected ${ }^{\mathrm{a}}$ & N/A \\
\hline 02108019415 & None detected ${ }^{\mathrm{a}}$ & N/A \\
\hline 02108019416 & Cs-137 & $5.5 \pm 1.9 \mathrm{E}-02$ \\
\hline 02108019417 & Cs-137 & $1.0 \pm 0.3 \mathrm{E}-01$ \\
\hline 02108019418 & None detected ${ }^{\mathrm{a}}$ & N/A \\
\hline 02108019419 & None detected ${ }^{\mathrm{a}}$ & N/A \\
\hline 02108019420 & None detected ${ }^{\mathrm{a}}$ & N/A \\
\hline 02108019421 & Cs-137 & $10.0 \pm 2.0 \mathrm{E}-02$ \\
\hline
\end{tabular}

a. No manmade gamma-emitting radionuclide contaminants were detected above background. 
Table 8. Results of Phase II Sr-90 and alpha spectrum analyses (pCi/g).

\begin{tabular}{|c|c|c|c|c|c|c|c|c|c|c|c|c|c|}
\hline $\begin{array}{l}\text { Sample } \\
\text { number }\end{array}$ & ${ }^{90} \mathrm{Sr}$ & ${ }^{241} \mathrm{Am}$ & ${ }^{243} \mathrm{Am}$ & ${ }^{242} \mathrm{Cm}$ & ${ }^{244} \mathrm{Cm}$ & ${ }^{238} \mathrm{Pu}$ & $239 / 240 \mathrm{Pu}$ & ${ }^{234} \mathrm{U}$ & ${ }^{235} \mathrm{U}$ & ${ }^{238} \mathrm{U}$ & ${ }^{228} \mathrm{Th}$ & ${ }^{230} \mathrm{Th}$ & ${ }^{232} \mathrm{Th}$ \\
\hline 02108019412 & $\mathrm{U}$ & UJ & $\mathrm{U}$ & $\mathbf{U}$ & $\mathbf{U}$ & $\mathbf{U}$ & $\mathbf{U}$ & $\begin{array}{l}1.032 \\
\pm 0.143\end{array}$ & $\begin{array}{l}0.032 \\
\pm 0.014\end{array}$ & $\begin{array}{l}0.164 \\
\pm 0.159\end{array}$ & $\begin{array}{l}1.367 \\
\pm 0.246\end{array}$ & $\begin{array}{l}1.374 \\
\pm 0.244\end{array}$ & $\begin{array}{l}1.286 \\
\pm 0.233\end{array}$ \\
\hline 02108019416 & $\mathrm{U}$ & UJ & $\mathrm{U}$ & $\mathrm{U}$ & $\begin{array}{l}0.018 \\
\pm 0.011\end{array}$ & $\mathbf{U}$ & $\mathbf{U}$ & $\begin{array}{l}1.052 \\
\pm 0.142\end{array}$ & $\begin{array}{l}0.034 \\
\pm 0.014\end{array}$ & $\begin{array}{l}1.079 \\
\pm 0.146\end{array}$ & $\begin{array}{l}0.300 \\
\pm 0.220\end{array}$ & $\begin{array}{l}1.322 \\
\pm 0.221\end{array}$ & $\begin{array}{l}1.297 \\
\pm 0.219\end{array}$ \\
\hline
\end{tabular}

$\mathrm{U}=$ Result is a statistical nondetect at the $95 \%$ confidence level. 


\section{LESSONS LEARNED}

Six significant lessons were learned during this project:

1. Containers of various chemicals were left in the boiler room when CFA-669 was shut down in 1981. The labels on some of these containers were missing, and some containers were in poor physical condition. Disposal of these stored chemicals required considerable time and effort, resulting in unanticipated costs and project delays because the chemicals were not identified and documented during pre-D\&D characterization. Pre-D\&D characterization should include identification and documentation of stored chemicals in order to plan properly for their disposal.

2. The CFA- 669 HSP required numerous revisions during the course of the project because requirements changed. Detailed requirements should not be specified in the HSP but, rather, should be given by referencing another document. An example is to reference the latest revision of the Radiological Controls Manual instead of specifying the dosimetry requirements in the HSP.

3. The D\&D of CFA- 669 began during the winter when the roof was covered with several inches of snow. The inside of the building was heated, and because the roof leaked, water leaked into the building, causing delays and added costs to collect, analyze, and dispose of the water. The roof should have been repaired before the start of D\&D.

4. The D\&D of CFA-669 was performed by available INEL craftsmen and not a dedicated crew. This caused additional projectspecific training, reduced productivity, and increased costs. The D\&D operations should have been performed by a dedicated crew.

5. Isolation of CFA- 669 before the start of $D \& D$ included cutting and plugging all underground piping at the project boundary. During excavation of the hot-waste drain line, the backhoe ruptured the radiologically contaminated concrete pipe, causing contamination spread, delays, and additional cost to containerize the contaminated soil. The backhoe should not have been used to completely dig out the pipe. Instead, the final foot of soil should have been removed with hand tools.

6. During plasma-arc torch cutting of steel plates too thick for mechanical cutting, numerous problems caused delays and added costs. These problems could have been reduced by ensuring that operating personnel were familiar with plasma-arc equipment capabilities and operating requirements. 


\section{REFERENCES}

1. K. J. Liekhus, Characterization and Decision Analysis for the Old Hot Laundry Facility (CFA-669), EGG-10034, May 1992.

2. R. S. Rice et al., Abbreviated Sampling and Analysis Plan for the Old Hot Laundry Facility (CFA-669), EGG-WM-9394, March 1991.

3. D. L. Smith, Decontamination and Decommissioning Plan for CFA-669 Hot Laundry, EGG-WM-10125, Revision 1, November 1992.

4. C. E. Klassy, Safety Analysis Report for the Decontamination and Decommissioning of the Hot Laundry Facility (CFA-669), WM-ERP-92-017, Revision 1, February 1993.

5. D. R. Lipp and D. L. Smith, Health and Safety Plan for Decontamination and Decommissioning the Central Facilities Area-669 Hot Laundry, EGG-WM-10170, Revision 2, November 1993.

6. D. R. Lipp, Radiological Survey Plan for CFA-669 Hot Laundry, ER-93-028, July 1993.

7. D. L. Smith, Post-decommissioning Characterization Plan for the CFA-669 Hot Laundry Facility Site, ER-93-032, May 1994.

8. J. Light, Sampling and Analysis Plan for the Sampling of Soil at CFA:669, ER-94-038, May 1994.

9. D. L. Smith, Post-D\&D Characterization Report for CFA-669 Site, INEL-94/0138, January 1995. 